\title{
AMICUS CURIAE À SOLICITAÇÃO DE OPINIÃO CONSULTIVA FORMULADA PELA COMISSÃ̃O AMERICANA DE DIREITOS HUMANOS SOBRE ENFOQUES DIFERENCIADOS EM MATÉRIA DE PESSOAS PRIVADAS DE LIBERDADE
}

\section{AMICUS CURIAE ON THE REQUEST FOR CONSULTATIVE OPINION FORMULATED BY THE AMERICAN COMMISSION ON HUMAN RIGHTS ABOUT DIFFERENTIATED APPROACHES REGARDING PERSONS DEPRIVED OF LIBERTY}

Recebimento: 29 abr. 2021

Aceitação: 6 maio 2021

\begin{abstract}
Como citar este trabalho / How to cite this work (informe a data atual de acesso / inform the current date of access):

GIAMBERARDINO, André Ribeiro et al. Amicus curiae à solicitação de opinião consultiva formulada pela Comissão Americana de Direitos Humanos sobre Enfoques Diferenciados em Matéria de Pessoas Privadas de Liberdade. Revista da Faculdade de Direito UFPR, Curitiba, v. 66, n. 2, p. 253-321, maio/ago. 2021. ISSN 2236-7284. Disponível em: https://revistas.ufpr.br/direito/article/view/80811. Acesso em: 31 ago. 2021. DOI: http://dx.doi.org/10.5380/rfdufpr.v66i2.80811.
\end{abstract}

\section{RESUMO}

Trata-se de razões de amicus curiae apresentadas à Corte Interamericana de Direitos Humanos pelo Núcleo de Estudos em Sistemas de Direitos Humanos e Clínica de Acesso à Justiça e Educação nas Prisões da Universidade Federal do Paraná, por ocasião da Solicitação de Opinião Consultiva (OC) número 29 formulada pela Comissão Americana de Humanos à Corte Interamericana, sobre enfoques diferenciados em matéria de pessoas privadas de liberdade. A peça parte do contexto da pandemia da COVID-19 que aguçou vulnerabilidades e sujeitou a população carcerária como um todo a um quadro de hipervulnerabilidade, diante das medidas sanitárias que implicam em redução de direitos e em fragilização dos meios de fiscalização. Ainda, avança sobre outros contextos de vulnerabilidades superpostas como em relação às mulheres transgênero, o público LGBTQI+, mulheres gestantes, lactantes e acompanhadas de crianças no cárcere. Por fim, ataca-se as ausências da solicitação de OC em relação à outras vulnerabilidades não elencadas explicitamente pela solicitação da CIDH, como é o caso de pessoas com deficiência privadas de liberdade, com especial ênfase à deficiência visual e aos casos de necessidade de uso de cadeiras de rodas que necessitam de cuidados específicos e inexistentes no sistema penitenciário.

\begin{abstract}
These are reasons for amicus curiae presented to the Inter-American Court of Human Rights by the Center for Studies in Human Rights Systems and the Clinic for Access to Justice and Education in the Prisons of the Federal University of Paraná, on the occasion of the Request for Advisory Opinion (OC) number 29 formulated by the American Commission of Humans to the Inter-American Court, on different approaches to the matter of persons deprived of their liberty. The play is part of the context of the pandemic of COVID-19, which heightened vulnerabilities and subjected the prison population as a whole to a framework of hyper vulnerability, given the sanitary measures that imply reduced rights and weakened means of enforcement. Still, it advances on other contexts of overlapping vulnerabilities, such as concerning transgender women, the LGBTQI + public, pregnant
\end{abstract}


women, breastfeeding women, and those accompanied by children in prison. Finally, the absence of the OC about other vulnerabilities not explicitly listed by the request of the IACHR, such as persons with disabilities deprived of liberty, with special emphasis on visual impairments and cases of need for use of wheelchairs with special needs, should be addressed.

As pesquisadoras e os pesquisadores da Universidade Federal do Paraná vinculados ao NÚCLEO DE ESTUDOS EM SISTEMAS DE DIREITOS HUMANOS (NESIDH - UFPR) e à CLÍNICA DE ACESSO À JUSTIÇA E EDUCAÇÃO NAS PRISÕES (CAJEP - UFPR), abaixo firmados e cujos documentos pessoais estão em anexo, apresentam à honorável Corte Interamericana de Direitos Humanos (doravante “Corte” ou “Corte IDH”) amicus curiae (doravante “AC”) em relação ao pedido de opinião consultiva (doravante “OC”) sobre enfoques diferenciados em matéria de pessoas privadas de liberdade, realizado pela Comissão Interamericana de Direitos Humanos (doravante “Comissão” ou “CIDH”), em 25 de novembro de 2019.

Ambos os projetos se uniram com a intenção de apresentar amicus curiae em atenção a alguns aspectos do pedido de opinião consultiva formulado pela CIDH sobre "Enfoques Diferenciados em matéria de Pessoas Privadas de Liberdade”.

\section{Legitimidade das Requerentes como amicus curiae e cumprimento dos requisitos de admissibilidade}

A figura do amicus curiae é um instrumento capaz de democratizar a jurisdição interamericana ao permitir que os requerentes sejam ouvidos e atuem junto à Corte de maneira colaborativa. Isso reflete a importância dada à participação plural de atores sociais para uma melhor compreensão de conflitos de natureza complexa e de amplo impacto.

O pedido ora formulado tem por fundamento a contribuição que o NESIDH e a CAJEP, ambos vinculados à Faculdade de Direito da UFPR, podem prestar ao julgamento de tema tão sensível e caro aos direitos humanos e direitos fundamentais, de modo a cumprir o requisito de órgão ou entidade especializada, com representatividade adequada.

O Núcleo de Estudos em Sistemas de Direitos Humanos da Universidade Federal do Paraná (NESIDH/UFPR) é um grupo de pesquisadores coordenado pela Professora Doutora Melina Girardi Fachin, albergado sob o Centro de Estudos da Constituição (CCONS) da UFPR e integrante do grupo Constitucionalismo e Democracia, da pós-graduação em Direito da UFPR. O grupo objetiva aprofundar debates sobre os sistemas de proteção dos direitos humanos, primando pela capacitação de juristas. 
Por sua vez, a Clínica de Acesso à Justiça e Educação nas Prisões (CAJEP/UFPR) é um projeto de extensão com modelo de clínica jurídica, coordenada pelo Professor Doutor André Ribeiro Giamberardino. A clínica promove atividades de articulação de projetos de pesquisa sobre controle social e sistema penitenciário; assistência jurídica à população carcerária, em parceria com a Defensoria Pública do Estado do Paraná (Brasil), e promoção de atividades educacionais no interior de estabelecimentos penais.

O NESIDH/UFPR e a CAJEP/UFPR, enquanto núcleos de pesquisa e extensão, são órgãos despersonalizados, mas possuem vinculação formal e material à Faculdade de Direito da UFPR. A especialização e representatividade dos núcleos se dá na medida em que as práticas e debates envolvendo direitos humanos e fundamentais são pilares fundamentais de reflexão e estudo dos docentes, discentes e pesquisadores do Direito que compõem os Centros de investigação.

Além disso, há pertinência temática direta com o objeto da presente OC formulada na medida em que a tutela de grupos vulneráveis, no contexto do sistema prisional, é objeto permanente de pesquisa, debate e diálogo no âmbito destes Centros de Estudos e Pesquisas. Assim, ao ingressar como amicus curiae, estes podem trazer tanto discussões doutrinárias e jurisprudenciais sobre aspectos que versa a OC, quanto elementos sobre a situação prisional atual e os grupos vulneráveis neste contexto.

Ante a relevância da questão suscitada, suas repercussões na esfera dos direitos humanos e da relação entre temas caros à sua atuação, NESIDH/UFPR e a CAJEP/UFPR vêm solicitar admissão na condição de amicus curiae.

\section{Premissa metodológica}

A premissa da qual parte este memorial é a de que a responsabilidade primeira de proteção da pessoa humana, seja pelo princípio da soberania, seja pela maior proximidade com a realidade fática, recai sobre os Estados. O princípio da subsidiariedade não elide, mas apenas reforça, a necessária convivência harmoniosa dos sistemas regionais (Interamericano, Africano e o Europeu) e dos sistemas de pretensão universal (no caso da Organização das Nações Unidas) com aqueles de proteção interna e de caráter local.

O ideal básico que se pretende alcançar se baseia na teoria do diálogo das fontes, cunhada pelo jurista alemão Erik Jayme, em 1995, na qual as normas jurídicas não se excluem simplesmente 
por pertencerem a ramos jurídicos distintos, mas, ao contrário, se completam, primando pela visão unitária do ordenamento jurídico ${ }^{1}$.

Tal teoria deve ser ressignificada no direito internacional, pois “é condição necessária para a ordem e a justiça do direito internacional ao enfatizar a coerência das normas que o integram”2, em especial por se tratar de sistemas com o mesmo objetivo comum, o da proteção da pessoa humana.

Por isso, deve haver interação na interpretação da Convenção Americana de Direitos Humanos (doravante “CADH”) e demais diplomas vigentes no âmbito de atuação da Corte IDH com outros diplomas internacionais de direitos humanos.

É nesse sentido que se ressalta a importância de que, na elaboração da OC aqui tratada, seja desenvolvido amplo diálogo entre os instrumentos de proteção dos direitos humanos, de forma a consolidar o propósito de firmar entendimentos cada vez mais coesos e favoráveis à proteção da dignidade humana ${ }^{3}$.

A Corte IDH, em especial, goza de uma das mais abrangentes capacidades consultivas a nível mundial, mostrando-se, como se depreende da OC $n^{\circ} 1 / 82$, disposta a extrapolar o âmbito da CADH e alcançar em seu processo deliberativo outros tratados que versem sobre a mesma matéria ${ }^{4}$.

Ainda, deve haver confrontação com precedentes de outros Sistemas, bem como demais manifestações deles advindas. Não tendo o Sistema Interamericano de Direitos Humanos (doravante “SIDH”) desenvolvido muitas balizas próprias acerca do tratamento de mulheres privadas de liberdade, especialmente nos termos propostos pela CIDH, é positivo recorrer, como feito em outros $\operatorname{casos}^{5}$, a julgados de Sistemas que já tenham se aprofundado no tema.

A própria jurisprudência da Corte IDH, embora particularmente tímida quando se trata de detentas, já revela o notável grau de importância de precedentes e doutrinas externas a seu próprio contexto. A título exemplificativo, o conceito mais utilizado pela Corte de "violência contra a mulher" (no sentido de reforço da discriminação sofrida por esse grupo) é extraído de julgados do Tribunal

TARTUCE, Flávio. Manual de Direito Civil. Rio de Janeiro: Forense, 2011, v. único, p. 57.

2 DO AMARAL JÚNIOR, ALBERTO. "Diálogo" das Fontes: fragmentação e coerência no Direito Internacional Contemporâneo. III ANUÁRIO BRASILEIRO DE DIREITO INTERNACIONAL. Belo Horizonte, v. 2, 2008.

3 DO AMARAL JÚNIOR, ALBERTO. "Diálogo" das Fontes: fragmentação e coerência no Direito Internacional Contemporâneo. III ANUÁRIO BRASILEIRO DE DIREITO INTERNACIONAL. Belo Horizonte, v. 2, 2008.

4 CAUSANILHAS, Tayara; LEGALE, Siddharta. A Opinião Consultiva N. 01/82 da Corte IDH: uma "metaopinião"?. Informativo do Núcleo Interamericano de Direitos Humanos da Faculdade Nacional de Direito da UFRJ, [s. l.], 2018. Disponível em: https://nidh.com.br/a-opiniao-consultiva-n-1-82-da-corte-idh-uma-metaopiniao/. Acesso em: 15 out. 2020.

5 CORTE IDH. Caso Wong Ho Wing Vs. Perú. Excepción Preliminar, Fondo, Reparaciones y Costas. Sentencia de 30 de junio de 2015. 
Europeu de Direitos Humanos ${ }^{6}$. Ademais, já foi utilizada como parâmetro pela Corte a determinação do Alto Comissariado das Nações Unidas para os Direitos Humanos de que as mulheres detidas "não devem sofrer discriminação e devem ser protegidas de todas as formas de violência ou exploração"7, bem como devem ser observadas as Regras Mínimas das Nações Unidas para o tratamento de reclusos como fonte de conteúdo indicativo do tratamento digno e humano a ser dado às pessoas privadas de liberdade ${ }^{8}$.

As trocas com outros Sistemas, portanto, revelam-se como ferramenta primordial para a realização da pretensão de interpretação dos tratados de direitos humanos como instrumentos vivos, “cuja interpretação tem que se adequar à evolução dos tempos e, em particular, às condições de vida atuais"9.

Assim, o presente AC defende a adoção de uma perspectiva de diálogo sistemático e de complementaridade entre essas fontes ${ }^{10}$.

\section{Preambularmente}

A solicitação apresentada pela Comissão tem por objeto que a Corte realize:

[...] uma interpretação conjunta de várias normas interamericanas sobre as obrigações diferenciadas que o princípio de igualdade e não discriminação impõe aos Estados no contexto de privação de liberdade, a fim de enfrentar a situação de desigualdade real de grupos em situação especial de risco. Especificamente, de mulheres grávidas, em período de pós-parto e lactantes; pessoas LGBTs, pessoas indígenas, pessoas idosas; e crianças que vivem com as mães na prisão ${ }^{11}$.

Recebida a solicitação, a Corte convidou todos os interessados a apresentar opinião escrita sobre os pontos submetidos à consulta, o que se passa a fazer nos moldes a seguir descritos.

Preliminarmente, desenvolver-se-á uma análise sobre o contexto de extrema vulnerabilidade das populações nas Américas, em especial as populações carcerárias, e sobre como grupos em

6 CORTE IDH. Caso Veliz Franco y otros Vs. Guatemala. Excepciones Preliminares, Fondo, Reparaciones y Costas. Sentencia de 19 de mayo de 2014. Serie C No. 277, par. 207.

7 CORTE IDH. Caso del Penal Miguel Castro Castro Vs. Perú. Fondo, Reparaciones y Costas. Sentencia de 25 de noviembre de 2006. Serie C No. 160, par. 303.

8 CORTE IDH. Caso Fleury y otros Vs. Haití. Fondo y Reparaciones. Sentencia de 23 de noviembre de 2011. Serie C No. 236, par. 83.

9 NOWAK, Bruna. Entre Diálogos e Monólogos: um estudo sobre as referências da corte internacional de justiça à jurisprudência das cortes regionais de direitos humanos. Orientador: Melina Girardi Fachin. p. 117. Dissertação (Mestre em Direitos Humanos e Democracia no Curso de Pós-Graduação em Direito) - Universidade Federal do Paraná, Curitiba, 2018. p. 45.

10 DO AMARAL JÚNIOR, Alberto. O “Diálogo” das Fontes: fragmentação e coerência no Direito Internacional Contemporâneo. III Anuário Brasileiro de Direito Internacional. Belo Horizonte, v. 2, 2008.

11 CIDH. Solicitação de parecer consultivo à Corte Interamericana de Direitos Humanos sobre enfoques diferenciados em matéria de pessoas privadas da liberdade, par. 2. 
situação especial de risco sofrem com o impacto desproporcional ocasionado pela falta de proteção diferenciada. Evoluindo no tema, será abordada a questão de como os Estados devem adequadamente primar pela igualdade de seus cidadãos.

No ponto, serão apresentadas as bases teóricas e convencionais que justificam a hermenêutica permissiva dos enfoques diferenciados em matéria de pessoas privadas de liberdade no âmbito do SIDH e em outros sistemas regionais e internacionais que dialogam com a questão aqui tratada.

Ainda, será feita breve exposição sobre a necessidade de inclusão das pessoas com deficiência que se encontram em situação de privação de liberdade no grupo de pessoas em situação especial de risco.

Em continuação, esclarecendo o enfoque de gênero aqui adotado, seguir-se-ão as reflexões sobre a maternidade na prisão e seus reflexos na vida das crianças que têm pais encarcerados.

Finalmente, serão apresentadas as considerações finais, em resposta às perguntas formuladas pela Comissão em sua solicitação, apoiando que a interpretação dos artigos 24 e 1.1 da Convenção indica a necessidade da adoção de medidas pelos Estados signatários para garantir que circunstâncias específicas de certos grupos de pessoas, em especial as mulheres, não afetem sua igualdade de condições com os demais cidadãos inseridos no contexto da privação da liberdade.

\section{IIIa. Vulnerabilidades e desigualdades das pessoas privadas de liberdade}

A noção de vulnerabilidade, no âmbito do Direito Internacional, está prevista na Declaração Universal sobre Bioética e Direitos Humanos da Organização das Nações Unidas para a Educação, a Ciência e a Cultura (UNESCO), em seu art. $8^{\circ}$ ("Respeito pela vulnerabilidade humana e integridade pessoal”), in verbis:

Na aplicação e no avanço dos conhecimentos científicos, da prática médica e das tecnologias que lhes estão associadas, deve ser tomada em consideração a vulnerabilidade humana. Os indivíduos e grupos particularmente vulneráveis devem ser protegidos, e deve ser respeitada a integridade pessoal dos indivíduos em causa ${ }^{12}$.

Daí se depreende a noção de que há indivíduos e grupos mais vulneráveis que outros, bem como de que aqueles em condição mais desfavorável devem ser especialmente resguardados.

12 ORGANIZAÇÃO DAS NAÇÕES UNIDAS PARA A EDUCAÇÃO, A CIÊNCIA E A CULTURA. Declaração Universal sobre Bioética e Direitos Humanos. Tradução pela Comissão Nacional da Unesco — Portugal. Disponível em: https://unesdoc.unesco.org/ark:/48223/pf0000146180_por.locale=en. Acesso em: 6 out. 2020. 
Importante salientar que a vulnerabilidade pode resultar não só de características físicas e psicológicas inerentes à condição humana, mas também de aspectos sociais e econômicos de determinado local, em especial pela existência de complexas "situações de mal-estar social a que estão sujeitas diversas populações mundo afora”13.

Situações de vulnerabilidade social podem ter origem na fraca "disponibilidade de serviços públicos; [n]a qualidade do meio ambiente; ou, ainda, [n]os graus de liberdade individual e política que uma sociedade oferece"14.

Nas Américas, as forças do livre mercado exercem grande poderio político e econômico que resultam em constantes negativas de pleno acesso aos direitos econômicos, sociais e culturais pelas camadas mais carentes das populações, o que agrava sua vulnerabilidade.

Esse cenário não é resultado apenas do atual contexto político-econômico mundial, mas de séculos de dominação e exploração que colocam o continente, sobretudo a América Latina, como uma região vulnerável no cenário internacional ${ }^{15}$. De certo, com poderio econômico superior ao do continente africano, entretanto, mais desigual.

A enorme disparidade social somada à precariedade institucional dos países latinoamericanos, ambas agravadas pela globalização do capital, têm efeitos desastrosos na parcela da população que mais depende da atuação estatal para garantir seus direitos básicos. A verdade é que o modelo econômico vigente "não oferece aos membros da sociedade a garantia de manutenção das condições minimamente dignas de vida, o que fragiliza, pouco a pouco, a existência individual e coletiva”16.

Nesse contexto, verifica-se que a falta da efetiva proteção do Estado reduz a autonomia do ser humano e influencia suas escolhas acerca da sua qualidade de vida, já que sem a garantia de um mínimo existencial, não há subjetividade autônoma para tal escolha ${ }^{17}$.

13 INSTITUTO DE PESQUISA ECONÔMICA APLICADA (IPEA). Texto para discussão 2364: Vulnerabilidade Social no Brasil: conceitos, métodos e primeiros resultados para municípios e regiões metropolitanas brasileiras. [Sem edição]. Brasília/Rio de Janeiro: Instituto de Pesquisa Econômica Aplicada, 2018. p. 12.

14 INSTITUTO DE PESQUISA ECONÔMICA APLICADA (IPEA). Texto para discussão 2364: Vulnerabilidade Social no Brasil: conceitos, métodos e primeiros resultados para municípios e regiões metropolitanas brasileiras. [Sem edição]. Brasília/Rio de Janeiro: Instituto de Pesquisa Econômica Aplicada, 2018. p. 10.

15 GHISLENI, Pâmela Copetti; LUCAS, Doglas Cesar. Direitos Humanos e Vulnerabilidades Atravessadas. Revista Estudos Feministas, Florianópolis, v. 28, n. 2, e60174, 2020. Disponível em: https://doi.org/10.1590/1806-95842020v28n260174. Acesso em: 3 out. 2020.

16 SALDANHA, Jânia Maria Lopes; BOHRZ, Clara Rossato. A Vulnerabilidade nas Decisões da Corte Interamericana de Direitos Humanos: impacto nas políticas públicas e no modelo econômico dos Estados. Anuário de Derecho Constitucional Latinoamericano, Bogotá, ed. XXIII, p. 481-502, 2017.

17 GHISLENI, Pâmela Copetti; LUCAS, Doglas Cesar. Direitos Humanos e Vulnerabilidades Atravessadas. Revista Estudos Feministas, Florianópolis, v. 28, n. 2, e60174, 2020. Disponível em: https://doi.org/10.1590/1806-95842020v28n260174. Acesso em: 3 out. 2020. 
Ademais, a convergência dos diversos fatores de desigualdade gera um cenário de vulnerabilidades múltiplas e complexas. É o que Kimberlé Crenshaw ${ }^{18}$ chama de interseccionalidade. A saber:

A interseccionalidade pode ser entendida como uma ferramenta de análise que consegue dar conta de mais de uma forma de opressão simultânea. Com essa lente, os processos discriminatórios não são compreendidos isoladamente, nem se propõem uma mera adição de discriminações, mas sim, abraça-se a complexidade dos cruzamentos dos processos discriminatórios e a partir daí se busca compreender as condições específicas que deles decorrem $^{19}$.

Trata-se de conceito de suma importância cuja compreensão é essencial para a defesa dos direitos humanos, afinal, “a discriminação interseccional é particularmente difícil de ser identificada em contextos onde forças econômicas, culturais e sociais silenciosamente moldam o pano de fundo" 20 .

Essa perspectiva de análise se faz presente na jurisprudência da Corte IDH, que já reconheceu que uma situação de vulnerabilidade pode decorrer de múltiplos fatores, havendo, inclusive, situações específicas que derivam dessa intersecção. Nesse sentido, cita-se o Caso Ramírez Escobar e outros Vs. Guatemala: “la confluencia de factores de discriminación de manera interseccional resulta en una experiencia discriminatoria que se diferencia de la simple acumulación en contra de una persona de distintos causas discriminación”21.

Em que pese não haja um conceito pronto e acabado de discriminação, a Corte já indicou que esta se relaciona com

[...] toda distinción, exclusión, restricción o preferencia que se basen en determinados motivos, como la raza, el color, el sexo, el idioma, la religión, la opinión política o de otra índole, el origen nacional o social, la propiedad, el nacimiento o cualquier otra condición social, y que tengan por objeto o por resultado anular o menoscabar el reconocimiento, goce

18 CRENSHAW, Kimberlé. Documento para o Encontro de Especialistas em Aspectos da Discriminação Racial Relativos ao Gênero. Revista Estudos Feministas, Florianópolis, v. 10, n. 1, p. 171-188, Jan. 2002. Disponível em: http://www.scielo.br/scielo.php?script=sci_arttext\&pid=S0104-026X2002000100011\&lng=en\&nrm=iso. Acesso em: 18 out. 2020.

19 KYRILLOS, Gabriela M. Uma Análise Crítica sobre os Antecedentes da Interseccionalidade. Revista Estudos Feministas, Florianópolis, v. 28, n. 1, e56509, 2020. Disponível em: http://www.scielo.br/scielo.php?script=sci_arttext\&pid=S0104-026X2020000100204\&lng=en\&nrm=iso. Acesso em: 18 out. 2020.

20 CRENSHAW, Kimberlé. Documento para o Encontro de Especialistas em Aspectos da Discriminação Racial Relativos ao Gênero. Revista Estudos Feministas, Florianópolis, v. 10, n. 1, p. 171-188, Jan. 2002. Disponível em: http://www.scielo.br/scielo.php?script=sci_arttext\&pid=S0104-026X2002000100011\&lng=en\&nrm=iso. Acesso em: 18 out. 2020.

21 CORTE IDH. Caso Ramírez Escobar y otros Vs. Guatemala. Fondo, Reparaciones y Costas. Sentencia de 9 de marzo de 2018. Serie C No. 351. par. 277. 
o ejercicio, en condiciones de igualdad, de los derechos humanos y libertades fundamentales de todas las personas ${ }^{22}$.

Como dito, um dos efeitos da discriminação é o cenário de desigualdade estrutural e vulnerabilidades interseccionais que dificultam, ou mesmo impedem, a efetivação dos direitos fundamentais há gerações. O que apresenta correlação e reflexo direto nas estatísticas de encarceramento penal da população mais necessitada. Como afirma Eugenio Raúl Zaffaroni, é necessário eleger um inimigo e, não raro, esse papel recai sobre o mais débil ${ }^{23}$.

É possível afirmar, então, que as múltiplas vulnerabilidades estão estritamente relacionadas à ideia de restrições e desigualdades e que atenuar os riscos que afligem os suscetíveis de opressão é um dever estatal que decorre diretamente da ideia de busca pela igualdade.

A realidade prisional da América Latina é ambiente fértil para a convergência interseccional de várias vulnerabilidades humanas e, de forma intensa e concentrada, de diversas formas de discriminação presentes na sociedade. Afinal, a parcela da população submetida ao sistema prisional, do mesmo modo que a população em geral, apresenta subgrupos cuja proteção material efetiva demanda enfoque diferenciado em razão das peculiaridades que apresentam.

Assim, não basta reconhecer que todas as pessoas têm direito sem discriminação à igual proteção perante a lei ${ }^{24}$, pois apenas com a garantia formal da igualdade incorrer-se-ia em novas formas de discriminação e exclusão. É preciso, pois, ir além e garantir a efetiva aplicação da igualdade e ausência de discriminação e reconhecer que toda pessoa que se encontra em situação de vulnerabilidade é titular de uma especial proteção a ser prestada pelo Estado ${ }^{25}$ - o que ganha especial relevância em se tratando de pessoas privadas de liberdade, já que estão sob custódia estatal ${ }^{26}$.

É este o ponto crucial da solicitação de parecer consultivo à Corte IDH apresentada pela Comissão: a necessidade de reconhecer que dentre as pessoas privadas da liberdade há subgrupos em diferentes situações de vulnerabilidade, cujos fatores estão inter-relacionados e, por isso, demandam atuação ainda mais especial dos Estados.

22 CORTE IDH. Caso Gonzales Lluy y otros Vs. Ecuador. Excepciones Preliminares, Fondo, Reparaciones y Costas. Sentencia de 1 de septiembre de 2015. Serie C No. 298, par. 253.

23 ZAFFARONI, Eugenio Raúl. O Inimigo no Direito Penal. Tradução de Sérgio Lamarão. 3. ed. Rio de Janeiro: Revan, 2011. 224 p. (Pensamento Criminológico; 14).

24 CORTE IDH. Caso Yatama Vs. Nicaragua. Excepciones Preliminares, Fondo, Reparaciones y Costas. Sentencia de 23 de junio de 2005. Serie C No. 127, par. 185.

25 CORTE IDH. Caso Trabajadores de la Hacienda Brasil Verde Vs. Brasil. Excepciones Preliminares, Fondo, Reparaciones y Costas. Sentencia de 20 de octubre de 2016. Serie C No. 318.

26 CORTE IDH. Caso López y otros Vs. Argentina. Excepciones Preliminares, fondo, Reparaciones y Costas. Sentencia de 25 de noviembre de 2019. Serie C No. 396, par. 90. 
Nessa linha de ideias, essa Honorável Corte já manifestou que os Estados incorrem em responsabilidade internacional nos casos em que, apesar de verificada a discriminação estrutural e intersecional em relação a grupos ou pessoas individualizadas, não adotam medidas específicas para sua particular proteção. Tal conclusão vem da leitura conjunta dos artigos 1.1 e 24 da CADH, que, ao reconhecer a existência de desigualdades materiais consubstanciadas em vulnerabilidades de determinados grupos, justifica a quebra da igualdade formal em prol de sua efetiva proteção material ${ }^{27}$.

Portanto, no contexto de proteção de grupos vulneráveis dentre as pessoas privadas de liberdade, a concretização da proteção básica dos direitos em prol da isonomia permite ir além e “reconhecer a potência da diversidade” que "é fundamental para avançar em termos de direitos humanos”28, em especial quando essa potencialidade precisa ser resgatada e reintegrada à sociedade.

\section{Silêncios que falam: vulnerabilidades invisíveis}

\section{IVa. Pessoas com deficiência privadas de liberdade}

A solicitação de opinião consultiva formulada pela CIDH foca em alguns grupos vulneráveis dentre as pessoas privadas de liberdade presentes na América Latina. Ao fazer isso, omite-se sobre outras tantas vulnerabilidades emergentes e que demandam atuação concreta do Estado no sistema prisional. Tais omissões não foram camufladas pela CIDH, pelo contrário, as escolhas foram explicitamente justificadas ${ }^{29}$. Ainda assim, emergiria oportunidade para a Corte IDH tratar também de outras vulnerabilidades não elencadas explicitamente pela solicitação da CIDH. É o caso de pessoas com deficiência privadas de liberdade.

Para ilustrar o argumento, informações apresentadas pelo Levantamento Nacional de Informações Penitenciárias (INFOPEN) ${ }^{30}$, elaborado por órgão vinculado ao Ministério da Justiça do Brasil, indicam que o total de pessoas privadas de liberdade que possuem deficiência, seja ela de natureza intelectual, física, auditiva e/ou visual, tem aumentado significativamente.

27 CORTE IDH. Caso V.R.P., V.P.C. y otros Vs. Nicaragua. Excepciones Preliminares, Fondo, Reparaciones y Costas. Sentencia de 8 de marzo de 2018. Serie C No. 3502, par. 338.

28 GHISLENI, Pâmela Copetti; LUCAS, Doglas Cesar. Direitos Humanos e Vulnerabilidades Atravessadas. Revista Estudos Feministas, Florianópolis, v. 28, n. 2, e60174, 2020. Disponível em: https://doi.org/10.1590/1806-95842020v28n260174. Acesso em: 3 out. 2020.

$29 \mathrm{CIDH}$. Solicitação de parecer consultivo à Corte Interamericana de Direitos Humanos sobre enfoques diferenciados em matéria de pessoas privadas da liberdade, pars. 7 e 8.

30 Criado em 2014, o Levantamento Nacional de Informações Penitenciárias (INFOPEN) é um sistema que apresenta informações estatísticas do sistema penitenciário brasileiro. Essas informações são compiladas por meio de um formulário de coleta preenchido pelos próprios gestores de todos os estabelecimentos prisionais do país. 
Em 2014, a quantidade de pessoas com deficiência representava 0,8\% do total de presos das unidades que informaram esse dado, sendo 1.528 homens e 47 mulheres. Em 2017, os números totais aumentaram, sendo 3.955 homens e 170 mulheres, o que correspondia a 0,57\% do total de presos. Já em 2019, a mencionada parcela populacional correspondia a 0,84\% do total de reclusos, chegando ao número de 5.995 homens e 385 mulheres $^{31}$.

Muito embora essa parcela da população carcerária possa não parecer expressiva quando tomada por seu percentual, os números absolutos representam grande quantidade de pessoas que não podem ter suas necessidades específicas ignoradas pelo Estado, sobretudo que suas limitações pessoais “podem ser ampliadas pela condição de superlotação carcerária, ausência de acessibilidade e adaptação razoável, sem contar as consequências da falta de assistência específica”32.

No contexto brasileiro, a ineficiência estatal em relação a este grupo viola preceitos basilares e ignora dispositivos internos expressos na Lei $n^{\circ}$ 7.210/1984, que regula a Execução Penal no Brasil $^{33}$, os quais tratam a assistência à saúde como dever do Estado e direito da pessoa privada de liberdade.

A realidade brasileira, portanto, justifica que a OC consigne que o enfoque diferenciado no tratamento de pessoas privadas de liberdade abarque também as pessoas com deficiência.

Apesar de haver notáveis precedentes abordando a questão da pessoa com deficiência, como o caso Ximenes Lopez vs. Brasil, o caso Furlan e familiares vs. Argentina e o caso Chinchilla Sandoval e outros vs. Guatemala - este último inclusive citado pela Corte IDH como importante precedente de pessoas com deficiência privadas de liberdade -, a jurisprudência da Corte IDH sobre direitos das pessoas com deficiência ainda não é ampla ${ }^{34}$.

31 Dados apresentados pelo Levantamento Nacional de Informações Penitenciárias (INFOPEN), a partir da compilação de informações referentes ao segundo semestre do ano de 2019 . Disponível em: https://app.powerbi.com/view?r=eyJrIjoiZWI2MmJmMzYtODA2MC00YmZiLWI4M2ItNDU2ZmIyZjFjZGQ0Iiwi dCI6ImViMDkwNDIwLTQ0NGMtNDNmNy05MWYyLTRiOGRhNmJmZThlMSJ9. Acesso em: 6 out. 2020.

32 Cuida-se de informação apresentada pela Divisão de Atenção às Mulheres e Grupos Específicos do DEPEN em Nota Técnica $n^{\circ}$ 83/2020, vinculada ao Processo Administrativo $n^{\circ}$ 08016.016188/2017-05, que buscou orientar as administrações estaduais quanto aos procedimentos nas unidades prisionais, para o fim de garantir o atendimento adequado a essa parcela carcerária.

33 BRASIL. Lei 7.210/1984: institui a Lei de Execução Penal. Diário Oficial da União - Seção 1 - 13/07/1984, Página 10227 (Publicação Original). Disponível em: http://www.planalto.gov.br/ccivil_03/leis/17210.htm. Acesso em: 6 out. 2020.

34 Não se ignora a jurisprudência da CORTE IDH no sentido de que uma Opinião Consultiva “no debe abarcar, en forma exclusiva, temas sobre los que la Corte ya se ha pronunciado en su jurisprudencia, y [...] no debe procurar la resolución de cuestiones de hecho, sino que busca desentrañar el” (CORTE IDH. Opinión Consultiva 25/18. Série A, n.o 25, 30 de maio de 2018, par. 46). Não há, todavia, correspondência entre a potencialidade de tratar da prisão e pessoas com deficiência e o caso Chinchila Sandoval como havia, em solicitação de OC rechaçada em 2005, entre o pedido da CIDH sobre interpretação da pena de morte e a jurisprudência da CORTE IDH relativa à matéria (CORTE IDH. Rechazo de la Solicitud de Opinión Consultiva presentada por la Comisión Interamericana de Derechos Humanos. Resolução de 34 de junho de 2005.). Tampouco há reiterada jurisprudência na matéria de pessoas com deficiência 
Além disso, não obstante a proteção de pessoas com deficiência seja objeto da Convenção Interamericana para a Eliminação de Todas as Formas de Discriminação contra as Pessoas Portadoras de Deficiência, este é o único instrumento específico de proteção de direitos humanos do SIDH que não contempla a possibilidade de peticionamento individual perante a Comissão e a Corte. Tal fato contribui para que o tema não protagonize a jurisdição contenciosa da Corte IDH, reforçando ser oportuno que a OC permita avanço na sua análise.

Ainda, as perguntas gerais formuladas no item 78.A da Solicitação da CIDH de Opinião Consultiva elencam de forma meramente exemplificativa os grupos de detentos que podem ser considerados como especialmente vulneráveis. Com isso, há espaço para que a Corte se manifeste também acerca das pessoas com deficiência submetidas ao sistema prisional, consolidando o entendimento de que se consubstanciam como grupo de pessoas vulneráveis com direito à especial proteção.

Vale destacar que desde a OC $n^{\circ} 7 / 86$, a Corte entende que pode precisar, aclarar ou até mesmo reformular perguntas que lhe foram feitas no exercício da competência consultiva, desde que os esclarecimentos, precisões ou reformulações não sejam feitos de forma contrária ao conteúdo da solicitação da Opinião Consultiva ou à intenção da pergunta ${ }^{35}$. Este entendimento, longe de ser isolado no final do século passado, entrecorta o exercício da função consultiva pela Corte IDH até os dias atuais, inclusive com a afirmação na OC n 25/18 (último parecer emitido no momento de apresentação deste $\mathrm{AC}$ ) que a Corte "no está necesariamente constreñida a los literales términos de las consultas que se le formulan"36.

Foi exercendo essa faculdade de aclaramento e reformulação que, por exemplo, na OC $n^{\circ}$ 16/99, a Corte IDH estabeleceu recortes fáticos para responder a perguntas formuladas, naquela ocasião, pelo México sobre o direito à assistência consular ${ }^{37}$.

No presente caso, ao trazer outros grupos vulneráveis, como pessoas com deficiência, a Corte IDH estaria exercendo sua competência de interpretar e aclarar as normas do SIDH, relativas à proteção de pessoas privadas de liberdade pertencentes a grupos vulneráveis, com olhar ampliado às

\footnotetext{
como havia sobre direito das crianças e que levou a CORTE IDH, por exemplo, a rechaçar uma OC sobre castigos corporais, solicitada pela Comissão, em 2009 (CORTE IDH. Rechazo de la Solicitud de Opinión Consultiva presentada por la Comisión Interamericana de Derechos Humanos. Resolução de 27 de janeiro de 2009).

35 CORTE IDH. Opinión Consultiva 7/86. Série A, n. 7, parecer de 29 de agosto de 1986. par. 2.

36 CORTE IDH. Opinión Consultiva 25/18. Série A, n. 25, parecer de 30 de maio de 2018. par. 55.

37 CORTE IDH. Opinión Consultiva 16/99. Série A, n. 16, parecer de 01 de outubro de 1999.
} 
pessoas com deficiência. Isso não implica risco ao exercício de sua função consultiva, já que a referida inclusão não leva à não satisfação da pergunta formulada pela CIDH ${ }^{38}$.

\section{IVb. Mulheres transgênero privadas de liberdade}

Em observância aos princípios da igualdade e da não-discriminação, adota-se no presente AC o posicionamento de que tratar de mulheres privadas de liberdade também faz necessário abordar a questão das mulheres transgênero, cujos direitos são igualmente tutelados pela CADH.

A Corte IDH consolidou, em parecer consultivo OC $n^{\circ} 24 / 17$, que a orientação sexual, identidade de gênero e expressão de gênero são partes da construção da pessoa, permeando diversos aspectos de sua vida e que encontram proteção junto ao SIDH. Nesse sentido, "sexo e gênero devem ser percebidos como parte de uma construção de identidade que é o resultado da decisão livre e autônoma de cada pessoa, sem ter que estar sujeita à sua genitalidade”39.

De acordo com a campanha de informação pública das Nações Unidas, ONU Livres \& Iguais, o termo “transgênero”, por vezes abreviado como “trans”:

[...] é empregado para descrever uma variedade ampla de identidades de gênero - incluindo pessoas transexuais, travestis, cross-dressers, pessoas que se identificam como terceiro gênero e outras cujas aparência e características são percebidas como atípicas e cujo senso de seu próprio gênero é diferente daquele que lhe foi designado no momento do seu nascimento ${ }^{40}$.

A organização alerta que "em todas as partes do mundo, pessoas trans estão em maior risco de sofrer violência, assédio e discriminação"41 e as violações de direitos humanos dessas pessoas vão “de bullying e abuso verbal à negação de assistência médica, educação, trabalho e moradia, à

38 Esta é uma preocupação expressa por Roa Roa, segundo quem “aunque la facultad de reformular las consultas parece favorecer a los Estados y órganos consultantes porque la Corte subsana la falta de claridad de sus preguntas y facilita que se profiera la opinión consultiva, también genera muchas dudas la forma como ella la ha ejercido, en la medida en que algunas veces esta facultad puede conducir a que un cambio de la pregunta se convierta, en realidad, en un cambio en el fondo del objeto de la consulta. Esto conduce a emitir una opinión consultiva que no satisface los intereses o fines del Estado u órganos consultantes, a que se pierda todo el procedimiento realizado, y a que seguramente el Estado u órgano desista definitivamente de un pronunciamiento de la Corte sobre esos aspectos" (ROA ROA, Jorge. La Función Consultiva de la Corte Interamericana de Derechos Humanos. Universidad Externado de Colombia, 2011, ebook não paginado).

39 CORTE IDH. Parecer Consultivo OC 24/17. Identidade de gênero, igualdade e não discriminação a casais do mesmo sexo. 24 de novembro de 2017.

40 ONU Livres \& Iguais. Disponível em: https://www.unfe.org/pt-pt/definitions/. Acesso em: 20 out. 2020.

41 ONU Livres \& Iguais. Glossário. Disponível em: https://www.unfe.org/wp-content/uploads/2017/05/TransgenderPT.pdf. Acesso em: 20 out. 2020. 
criminalização, prisão e detenção arbitrária e à violência, lesão corporal, tortura, estupro e assassinato" 42 .

A violência (e o medo dela) faz parte do cotidiano de tal parcela de indivíduos. No caso brasileiro, conforme as informações do Boletim $n^{0} 03$ da Associação Nacional de Travestis e Transexuais (ANTRA), publicado em $2020^{43}$, somente neste ano, o número de assassinatos contra a população trans aumentou 39\% em comparação com o mesmo período do ano passado. Apesar de decisões judiciais recentes que buscam dar suporte e maior proteção à comunidade LGBTQI+, como a criminalização da homofobia ${ }^{44}$ e transfobia ${ }^{45}$, a falta de ação pelo Estado brasileiro para combater a transfobia é notável. A expectativa de vida da população trans no Brasil é de apenas 35 anos ${ }^{46}$, sendo um grupo marcado pela exclusão do mercado de trabalho e vítima de crimes de ódio.

Assim, se situações cotidianas de violência são elementos constituintes das identidades de muitas travestis e transexuais, na prisão, o choque entre a identidade de gênero e o (mal) funcionamento institucional amplifica tais experiências ${ }^{47}$. No cárcere, as experiências de violência pelas quais essas pessoas passam são ampliadas pelas próprias características do sistema prisional ${ }^{48}$.

Em seu Informe sobre violência contra a população LGBTQI+ na América, de 2015, esta Honorável Corte destaca que essa população enfrenta uma situação de múltiplas vulnerabilidades quando privada de liberdade:

[...] las personas LGBT se encuentran en el último escalafón de la jerarquía informal en los centros de detención, lo que da a lugar a una discriminación doble o triple, y son sometidas de manera desproporcionada a actos de torturas y otras formas de malos tratos. Asimismo, advirtió que las personas LGBT privadas de libertad enfrentan un riesgo mayor de violencia sexual, así como de otros actos de violencia y discriminación, a manos de otras personas privadas de libertad o del personal de custodia ${ }^{49}$.

42 ONU Livres \& Iguais. Nota Informativa: pessoas transgênero. Disponível em: https://www.unfe.org/wpcontent/uploads/2017/05/Transgender-PT.pdf. Acesso em: 20 out. 2020.

43 BRASIL. ANTRA - Associação Nacional de Travestis e Transexuais. Boletim n $\mathbf{0} 03$ - Assassinato Contra Travestis e Transexuais em 2020. Disponível em: https://antrabrasil.files.wordpress.com/2020/06/boletim-3-2020-assassinatosantra.pdf. Acesso em: 1 out. 2020.

44 BRASIL. Supremo Tribunal Federal. Ação Direta de Inconstitucionalidade No 26. Relator: Min. Celso de Mello. Brasília, 13/06/2019.

45 BRASIL. Supremo Tribunal Federal. Mandado de Injunção No 4733. Relator: Min. Edson Fachin. Brasília, 13/06/2019.

46 Expectativa de vida de transexuais é de 35 anos, metade da média nacional. (Agência Senado. Brasília, 20/06/2017. Disponível em: https://www12.senado.leg.br/noticias/especiais/especial-cidadania/expectativa-de-vida-detransexuais-e-de-35-anos-metade-da-media-nacional. Acesso em: 1 out. 2020).

47 SEFFNER, Fernando; PASSOS, Amilton Gustavo da Silva. Uma Galeria para Travestis, Gays e seus Maridos: forças discursivas na geração de um acontecimento prisional. Sexualidade, Salud y Sociedad: Revista Latinoamericana, n. 23, p. 140-160, maio-ago. 2016. p. 144-145.

48 NASCIMENTO, Francisco Elionardo de Melo. ONU Livres \& Iguais. Revista Estudos Feministas, Florianópolis, v. 28, n. 1, e57687, 2020. p. 6.

49 CIDH. Violencia contra Personas Lesbianas, Gay, Bisexuales, Trans e Intersex en América, 12 de noviembre de 2015, pars. 145 e 148. 
O Supremo Tribunal Federal brasileiro, quando do julgamento da Arguição de Descumprimento de Preceito Fundamental (ADPF) $347^{50}$, ao realizar controle de convencionalidade, reconheceu o Estado de Coisas Inconstitucional do Sistema Penitenciário brasileiro, tendo discutido sobre as violações de premissas básicas para grupos vulneráveis dentro do sistema carcerário. Naquele momento, o Ministro Celso de Mello assim destacou em seu voto:

O sentenciado, ao ingressar no sistema prisional, sofre uma punição que a própria Constituição da República proíbe e repudia, pois a omissão estatal na adoção de providências que viabilizem a justa execução da pena cria situações anômalas e lesivas à integridade de direitos fundamentais do condenado, culminando por subtrair ao apenado o direito - de que não pode ser despojado - ao tratamento digno.

Daí a advertência da Comissão Interamericana de Direitos Humanos, em um de seus "Informes sobre os direitos humanos das pessoas privadas de liberdade nas Américas" (2011), no sentido de que sempre que o sistema penitenciário de um País não merecer a atenção necessária e os recursos essenciais a serem providos pelo Estado, a função para a qual esse mesmo sistema está vocacionado distorcer-se-á e, em vez de os espaços prisionais proporcionarem proteção e segurança, eles se converterão em escolas de delinquência, propiciando e estimulando comportamentos antissociais que dão origem à reincidência e, desse modo, afastam-se, paradoxalmente, do seu objetivo de reabilitação ${ }^{51}$.

No tocante às violações de direitos básicos da população trans encarcerada, destaca-se, para ilustrar o argumento, o seguinte trecho de outro julgamento da Suprema Corte brasileira que, na ADPF 527, de relatoria do Ministro Luís Roberto Barroso, frisou:

21. Transexuais e travestis têm em comum a circunstância de integrarem um grupo extremamente estigmatizado. Têm dificuldade de permanecer na escola, de se empregar e até mesmo de obter atendimento médico nos hospitais públicos. Trata-se, ademais, de um grupo exposto a graves situações de violência, situações estas que colocam em risco a sua integridade física, psíquica e a sua própria vida. Basta lembrar que o Brasil lidera o ranking mundial de violência contra transgêneros, cuja expectativa média de vida, no país, gira em torno de 30 anos, contra os quase 75 anos de vida do brasileiro médio.

23. A população carcerária é, de igual modo, um grupo extremamente vulnerável e estigmatizado. Não conta com o apoio da sociedade, que é, em regra, antipática à tutela dos direitos dos presos, que vê como delinquentes. Não vota. Não dispõe de voz nas instâncias políticas majoritárias. Vive em celas lotadas e em condições subumanas. É vítima de todo tipo de violência e está inserida em um sistema que, no Brasil, já se reconheceu ensejar a violação em massa de direitos humanos, ao ponto de esta Corte ter declarado o "estado de coisas inconstitucional” do sistema carcerário, tal como estruturado atualmente (ADPF 347, Rel. Min. Marco Aurélio).

24. Transexuais e travestis encarceradas são, assim, um grupo sujeito a uma dupla vulnerabilidade, decorrente tanto da situação de encarceramento em si, quanto da sua identidade de gênero. Trata-se de pessoas ainda mais expostas e sujeitas à violência e à violação de direitos que o preso comum. De fato, segundo relatório da Organização das Nações Unidas, há registros contundentes, por parte de comitês antitortura e órgãos e entidades de defesa de direitos humanos, acerca da prática de violência física, de abuso e de escravização sexual nas prisões, especificamente dirigidas às populações LGBTI, em razão da sua identidade de gênero ou orientação sexual, eventualmente com o apoio de servidores

50 BRASIL. Supremo Tribunal Federal. Arguição de Descumprimento de Preceito Fundamental No 347. Relator: Min. Marco Aurélio Mello. Brasília, 09/09/2015.

51 BRASIL. Supremo Tribunal Federal. Arguição de Descumprimento de Preceito Fundamental No 347. Relator: Min. Marco Aurélio Mello. Brasília, 09/09/2015. p. 159. 
estatais, em situações equiparáveis a atos de tortura e de tratamento cruel no entendimento da própria $\mathrm{ONU}^{52}$.

Nesse mesmo julgamento, em diálogo com o direito internacional dos direitos humanos, fezse especial menção aos Princípios de Yogyakarta ${ }^{53}$, dentre os quais se destacam, para os fins aqui pretendidos:

Princípio 5: Direito à Segurança Pessoal

Toda pessoa, independente de sua orientação sexual ou identidade de gênero, tem o direito à segurança pessoal e proteção do Estado contra a violência ou dano corporal, infligido por funcionários governamentais ou qualquer indivíduo ou grupo. Os Estados deverão:

a) Tomar todas as medidas policiais e outras medidas necessárias para prevenir e proteger as pessoas de todas as formas de violência e assédio relacionadas à orientação sexual e identidade de gênero;

b) Tomar todas as medidas legislativas necessárias para impor penalidades criminais adequadas à violência, ameaças de violência, incitação à violência e assédio associado, por motivo de orientação sexual ou identidade de gênero de qualquer pessoa ou grupo de pessoas em todas as esferas da vida, inclusive a familiar;

c) Tomar todas as medidas legislativas, administrativas e outras medidas necessárias para garantir que a orientação sexual ou identidade de gênero da vítima não possa ser utilizada para justificar, desculpar ou atenuar essa violência;

d) Garantir que a perpetração dessas violências seja vigorosamente investigada e, quando provas adequadas forem encontradas, as pessoas responsáveis sejam processadas, julgadas e devidamente punidas, e que as vítimas tenham acesso a recursos jurídicos e medidas corretivas adequadas, incluindo indenização;

e) Realizar campanhas de conscientização dirigidas ao público em geral, assim como a perpetradores/ as reais ou potenciais de violência, para combater os preconceitos que são a base da violência relacionada à orientação sexual e identidade de gênero.

[...]

Princípio 9: Direito ao Tratamento Humano Durante a Detenção

Toda pessoa privada da liberdade deve ser tratada com humanidade e com respeito pela dignidade inerente à pessoa humana. A orientação sexual e identidade de gênero são partes essenciais da dignidade de cada pessoa. Os Estados deverão:

a) Garantir que a detenção evite uma maior marginalização das pessoas motivada pela orientação sexual ou identidade de gênero, expondo-as a risco de violência, maus-tratos ou abusos físicos, mentais ou sexuais;

b) Fornecer acesso adequado à atenção médica e ao aconselhamento apropriado às necessidades das pessoas sob custódia, reconhecendo qualquer necessidade especial relacionada à orientação sexual ou identidade de gênero, inclusive no que se refere à saúde reprodutiva, acesso à informação e terapia de HIV/Aids e acesso à terapia hormonal ou outro tipo de terapia, assim como a tratamentos de reassignação de sexo/gênero, quando desejado; c) Assegurar, na medida do possível, que todos os detentos e detentas participem de decisões relacionadas ao local de detenção adequado à sua orientação sexual e identidade de gênero; d) Implantar medidas de proteção para todos os presos e presas vulneráveis à violência ou abuso por causa de sua orientação sexual, identidade ou expressão de gênero e assegurar, tanto quanto seja razoavelmente praticável, que essas medidas de proteção não impliquem maior restrição a seus direitos do que aquelas que já atingem a população prisional em geral; e) Assegurar que as visitas conjugais, onde são permitidas, sejam concedidas na base de igualdade a todas as pessoas aprisionadas ou detidas, independente do gênero de sua parceira ou parceiro;

52 BRASIL. Supremo Tribunal Federal. Arguição de Descumprimento de Preceito Fundamental No 527. Relator: Min. Luís Roberto Barroso. Brasília, 26/06/2019.

53 Os Princípios de Yogyakarta são um documento sobre direitos humanos nas áreas de orientação sexual e identidade de gênero, publicado em novembro de 2006 como resultado de uma reunião internacional de grupos de direitos humanos na cidade de Joguejacarta, na Indonésia. 
f) Proporcionar o monitoramento independente das instalações de detenção por parte do Estado e também por organizações não-governamentais, inclusive organizações que trabalhem nas áreas de orientação sexual e identidade de gênero;

g) Implantar programas de treinamento e conscientização, para o pessoal prisional e todas as outras pessoas do setor público e privado que estão envolvidas com as instalações prisionais, sobre os padrões internacionais de direitos humanos e princípios de igualdade e nãodiscriminação, inclusive em relação à orientação sexual e identidade de gênero.

As pessoas travestis e transexuais privadas de liberdade, sujeitas a múltiplas vulnerabilidades e cujos direitos não têm sido garantidos de acordo com os parâmetros internacionais, "são contabilizadas como as vítimas mais frequentes de violências, discriminação e preconceito, ao mesmo tempo em que apresentam os menores índices de escolaridade” ${ }^{54}$.

Inclusive quando a violência leva à morte, essas pessoas se encontram em situação de abandono, tanto institucional quanto familiar, o que torna a morte de uma pessoa trans no sistema prisional um evento praticamente invisível ${ }^{55}$.

A fim de denunciar a grave situação de violação dos direitos humanos dessa população, organizações não-governamentais, como a Transgender Europe (TGEU) ${ }^{56}$, a Associação Nacional de Travestis e Transexuais (ANTRA) ${ }^{57}$ e Grupo Gay da Bahia (GGB), têm realizado levantamentos de casos de violência contra pessoas trans no Brasil, o que é sintomático de toda nossa região. Estes levantamentos seguem uma metodologia baseada na pesquisa de casos de violência em matérias de jornais e mídias veiculadas na internet, “de forma manual, individual e diária”58, bem como a partir de "relatos de pessoas locais, conhecidos ou instituições LGBTQI+ que publicam informações sobre pessoas assassinadas"59 e/ou enviam informações diretamente para as ONGs. Porém, tais entidades não conseguem sistematizar todos os casos de violência que ocorrem diariamente no país,

54 NASCIMENTO, Francisco Elionardo de Melo. Agrupamentos de Travestis e Transexuais Encarceradas no Ceará, Brasil. Revista Estudos Feministas, Florianópolis, v. 28, n. 1, e57687, 2020. p. 11.

55 SEFFNER, Fernando; PASSOS, Amilton Gustavo da Silva. Uma Galeria para Travestis, Gays e seus Maridos: Forças discursivas na geração de um acontecimento prisional. Sexualidade, Salud y Sociedad: Revista Latinoamericana, n. 23, p. 140-160, maio-ago. 2016. p. 149.

56 Transgender Europe (TGEU). Atualização do Monitoramento de Assassinato Trans (TMM). 2019. Disponível em: https://transrespect.org/en/tmm-update-trans-day-of-remembrance-2019/. Acesso em: 5 out. 2020.

57 BENEVIDES, Bruna G.; NOGUEIRA, Sayonara Naider Bonfim (Orgs). Dossiê dos Assassinatos e da Violência contra Travestis e Transexuais Brasileiras em 2019. São Paulo: Expressão Popular, ANTRA, IBTE, 2020. p. 15. Disponível em: https://antrabrasil.files.wordpress.com/2020/01/dossic3aa-dos-assassinatos-e-da-violc3aancia-contrapessoas-trans-em-2019.pdf. Acesso em: 5 out. 2020.

58 BENEVIDES, Bruna G.; NOGUEIRA, Sayonara Naider Bonfim (Orgs). Dossiê dos Assassinatos e da Violência contra Travestis e Transexuais Brasileiras em 2019. São Paulo: Expressão Popular, ANTRA, IBTE, 2020. p. 15. Disponível em: https://antrabrasil.files.wordpress.com/2020/01/dossic3aa-dos-assassinatos-e-da-violc3aancia-contrapessoas-trans-em-2019.pdf. Acesso em: 5 out. 2020.

59 BENEVIDES, Bruna G.; NOGUEIRA, Sayonara Naider Bonfim (Orgs). Dossiê dos Assassinatos e da Violência contra Travestis e Transexuais Brasileiras em 2019. São Paulo: Expressão Popular, ANTRA, IBTE, 2020. p. 15. Disponível em: https://antrabrasil.files.wordpress.com/2020/01/dossic3aa-dos-assassinatos-e-da-violc3aancia-contrapessoas-trans-em-2019.pdf. Acesso em: 5 out. 2020. 
principalmente aqueles que envolvem o sistema carcerário. Ainda, os (poucos) números publicados pelo Estado sobre pessoas trans presas infelizmente não acompanham a realidade.

A inexistência de dados oficiais sobre a violência contra pessoas trans privadas de liberdade no país representa um modo de agir do Estado:

A ideia de que a inexistência de dados confiáveis sobre a população LGBT os invisibiliza na promoção de políticas públicas no âmbito prisional parece equivocada. O não fazer é algo que deve ser entendido como inerente e não externo aos processos de Estado. Veja-se: ao não colocar as travestis e transexuais nas planilhas, o Estado o faz. Este também é o fazer do Estado por meio dos seus processos ${ }^{60}$.

A ausência de dados que considere orientação sexual e identidade de gênero, sem vinculação necessária ao sexo biológico, bem como a ausência de legislação em vigor que oriente as práticas estatais voltadas às pessoas LGBTQI+ em privação de liberdade, mostram-se como obstáculos à prevenção de violação de direitos humanos desta parcela da população.

Assim, uma das principais obrigações dos Estados para prevenir atos de violência contra a população trans privada de liberdade é o mapeamento, acompanhamento e controle quantitativo sobre essa população. Considerando as diferentes formas que os sujeitos se nomeiam e são nomeados na prisão e as dificuldades para essas pessoas afirmarem suas identidades de gênero, é provável que esse número seja aproximado e jamais exato, mas isso não diminui a importância do mapeamento ${ }^{61}$.

Grande parte dessa violência física e emocional sofrida no cárcere advém, inclusive, de uma outra violação, o desrespeito à identidade de gênero da pessoa que será privada de liberdade no momento do direcionamento à unidade prisional correspondente.

Frente a essa realidade, a Resolução nº 348 de 2020 do Conselho Nacional de Justiça (CNJ), órgão do Poder Judiciário brasileiro, estabeleceu o seguinte:

Art. $4^{\circ} \mathrm{O}$ reconhecimento da pessoa como parte da população LGBTI será feito exclusivamente por meio de autodeclaração, que deverá ser colhida pelo magistrado em audiência, em qualquer fase do procedimento penal, incluindo a audiência de custódia, até a extinção da punibilidade pelo cumprimento da pena, garantidos os direitos à privacidade e à integridade da pessoa declarante.

Parágrafo único. Nos casos em que o magistrado, por qualquer meio, for informado de que a pessoa em juízo pertence à população LGBTI, deverá cientificá-la acerca da possibilidade da autodeclaração e informá-la, em linguagem acessível, os direitos e garantias que lhe assistem, nos termos da presente Resolução ${ }^{62}$.

60 NASCIMENTO, Francisco Elionardo de Melo. Agrupamentos de Travestis e Transexuais Encarceradas no Ceará, Brasil. Revista Estudos Feministas, Florianópolis, v. 28, n. 1, e57687, 2020. p. 11.

61 FERREIRA, Guilherme Gomes; KLEIN, Caio Cesar; GOULART, Vincent Pereira. A Criação de Alas ou Galerias Específicas para LGBTs Presos como ‘Política Penitenciária’: contradições e disputas. Revista Sociologia Jurídica, n. 28, p. 21-36, abr. 2019. p. 24.

62 BRASIL. Conselho Nacional de Justiça. Resolução No 348 de 13/10/2020. Estabelece diretrizes e procedimentos a serem observados pelo Poder Judiciário, no âmbito criminal, com relação ao tratamento da população lésbica, gay, 
A não observância da autodeclaração apresenta efeitos nefastos, tal como, além da violência e da discriminação, a segregação dessas mulheres. São vários os relatos de transfobia por parte dos detentos e funcionários do sistema penitenciário, colocando esse grupo à margem do processo de ressocialização almejado pela Lei de Execução Penal brasileira.

Em virtude dessa exclusão, mulheres trans muitas vezes acabam por realizar trabalhos sexuais para obter itens básicos de sobrevivência, já que o Estado não fornece os insumos em quantidade suficiente para atender a demanda ou não lhes garante o seu direito de visita, de forma que essas pessoas deixam de receber ajuda de amigos, familiares ou companheiros.

O direito à visita íntima da pessoa privada de liberdade está garantido no art. 6 da Resolução Conjunta ${ }^{\circ} 1 / 2014$, do Conselho Nacional de Política Criminal e Penitenciária (CNPCP) e Conselho Nacional de Combate à Discriminação (CNCD/LGBT) com base legal na Lei 7.210/ 84, que prevê, em seu artigo 41, inciso X, o direito à “visita do cônjuge, da companheira, de parentes e amigos em dias determinados”“3. Contudo, para que possa ser garantido, em especial para a população trans, é necessário que o Estado invista recursos para normalizar a estrutura do sistema penitenciário, tanto a física como a pessoal, possibilitando o reconhecimento do indivíduo em um ambiente seguro, para que seus direitos sejam exercidos em liberdade.

Permanecer em celas com outros prisioneiros de gênero com o qual a pessoa trans não se identifica, põe sua vida em risco e as expõem a violências das mais variadas formas. Permitir que isso aconteça é uma clara violação dos direitos à vida e à integridade pessoal, protegidos pela CADH. É inconcebível que uma pessoa trans privada de liberdade, sob a responsabilidade do Estado, seja exposta a um regime de risco, ficando vulnerável à violência física, sexual e psicológica, sobretudo advinda de outros custodiados ${ }^{64}$.

Nesse sentido, é também de suma importância que a proteção seja integral e igualitária, com base nos artigos 1.1 e 24 da CADH, para evitar que outras formas de segregação sejam desencadeadas. O mapeamento não pode servir como base para o Estado separar e agrupar travestis e transexuais de

bissexual, transexual, travesti ou intersexo que seja custodiada, acusada, ré, condenada, privada de liberdade, em cumprimento de alternativas penais ou monitorada eletronicamente. DJe/CNJ n n 335/2020, de 15/10/2020.

63 BRASIL. Lei 7.210/ 1984: institui a Lei de Execução Penal. Diário Oficial da União - Seção 1 - 13/07/1984, Página 10227 (Publicação Original). Disponível em: http://www.planalto.gov.br/ccivil_03/leis/17210.htm. Acesso em: 5 out. 2020.

64 BRASIL. Ministério da Mulher, da Família e dos Direitos Humanos. LGBT nas prisões do Brasil: diagnóstico dos procedimentos institucionais e experiências de encarceramento. Brasília, 2020. Disponível em: https://www.gov.br/mdh/pt-br/assuntos/noticias/todas-as-noticias/2020-

2/fevereiro/TratamentopenaldepessoasLGBT.pdf. Acesso em: 5 out. 2020. p. 121. 
acordo com categorias tais como "vulneráveis", “menos perigosas” e "perigosas” e, a partir dessa classificação, garantir a proteção e integridade física apenas dos dois primeiros grupos ${ }^{65}$ :

Ao se definir quem merece ou não uma política prisional humanizada, são deliberados modelos de pessoas trans requerido pelo Estado. Um modelo de presos e presas pelo qual valeria a pena constituir políticas públicas humanizadas, mesmo porque é a partir desses sujeitos supostamente frágeis, inofensivos e vitimizados que o Estado potencializa sua imagem de Estado protetor ${ }^{66}$.

Divisões desse tipo acabariam por institucionalizar “uma lógica perversa de discriminação moral e segregação espacial como modo de gestão da vida e diminuição dos riscos dessas pessoas quando mantidas na prisão”67. Para que as alas específicas não signifiquem um projeto de separação social das mulheres trans, é necessária a capacitação de todos os agentes penitenciários, o mapeamento dessa população, a criação de espaços de convivência (grupos de leitura, espaços de estudo, hortas comunitárias, etc.) e o fortalecimento de processos de autogestão da população trans privada de liberdade, em respeito especialmente aos artigos 11.2, 13 e 24 da CADH.

Desse modo, para prevenir todo ato de violência contra pessoas trans privadas da liberdade que não impliquem segregação delas em relação ao restante da população carcerária, devem os Estados, acima de tudo, entender e valorizar as vozes e as identidades dos sujeitos que destoam do padrão masculino e heterossexual dominante. Devem, ainda, permitindo possibilidades de escolha para essa população, criar padrões mínimos de garantias que visem a igualdade de tratamento à toda população trans privada de liberdade em todo território nacional. Essas possibilidades podem se manifestar, por exemplo, com a criação de alas que englobam não somente a população trans, mas também seus companheiros e companheiras, garantindo a proteção da família, presente no artigo 17.1 da CADH.

Infelizmente, a criação de celas e alas específicas, apesar de ser de extrema importância para a proteção física dessa população, por si só, não garante que elas estarão livres da precariedade de políticas institucionais ${ }^{68}$ e de outras formas de violência, que não somente a física:

A criação de alas e galerias específicas para a população LGBT privada de liberdade não pode ser considerada política pública per si, uma vez que a existência desses espaços é a

65 NASCIMENTO, Francisco Elionardo de Melo. Agrupamentos de Travestis e Transexuais encarceradas no Ceará, Brasil. Revista Estudos Feministas, Florianópolis, v. 28, n. 1, e57687, 2020. p. 3.

66 NASCIMENTO, Francisco Elionardo de Melo. Agrupamentos de Travestis e Transexuais encarceradas no Ceará, Brasil. Revista Estudos Feministas, Florianópolis, v. 28, n. 1, e57687, 2020. p. 13.

67 NASCIMENTO, Francisco Elionardo de Melo. Agrupamentos de Travestis e Transexuais encarceradas no Ceará, Brasil. Revista Estudos Feministas, Florianópolis, v. 28, n. 1, e57687, 2020. p. 12.

68 BRASIL. Ministério da Mulher, da Família e dos Direitos Humanos. LGBT nas Prisões do Brasil: diagnóstico dos procedimentos institucionais e experiências de encarceramento. Brasília, 2020. Disponível em: https:/www.gov.br/mdh/pt-br/assuntos/noticias/todas-as-noticias/2020-

2/fevereiro/TratamentopenaldepessoasLGBT.pdf. Acesso em: 5 out. 2020. p. 121. 
consequência lógica da obrigação do Estado de tutelar a integridade física daqueles que decide encarcerar ${ }^{69}$.

Como destacado pelo Ministro do Supremo Tribunal Federal brasileiro Marco Aurélio, na já citada ADPF 347:

Os presídios e delegacias não oferecem, além de espaço, condições salubres mínimas. Segundo relatórios do Conselho Nacional de Justiça - CNJ, os presídios não possuem instalações adequadas à existência humana. Estruturas hidráulicas, sanitárias e elétricas precárias e celas imundas, sem iluminação e ventilação representam perigo constante e risco à saúde, ante a exposição a agentes causadores de infecções diversas. As áreas de banho e sol dividem o espaço com esgotos abertos, nos quais escorrem urina e fezes. Os presos não têm acesso a água, para banho e hidratação, ou a alimentação de mínima qualidade, que, muitas vezes, chega a eles azeda ou estragada. Em alguns casos, comem com as mãos ou em sacos plásticos. Também não recebem material de higiene básica, como papel higiênico, escova de dentes ou, para as mulheres, absorvente íntimo. A Clínica UERJ Direitos informa que, em cadeia pública feminina em São Paulo, as detentas utilizam miolos de pão para a contenção do fluxo menstrual.

Além da falta de acesso a trabalho, educação ou qualquer outra forma de ocupação do tempo, os presos convivem com as barbáries promovidas entre si. São constantes os massacres, homicídios, violências sexuais, decapitação, estripação e esquartejamento. Sofrem com a tortura policial, espancamentos, estrangulamentos, choques elétricos, tiros com bala de borracha. Quanto aos grupos vulneráveis, há relatos de travestis sendo forçados à prostituição. Esses casos revelam a ausência de critério de divisão de presos por celas, o que alcança também os relativos a idade, gravidade do delito e natureza temporária ou definitiva da penalidade.

O sistema como um todo surge com número insuficiente de agentes penitenciários, que ainda são mal remunerados, não recebem treinamento adequado, nem contam com equipamentos necessários ao desempenho das próprias atribuições. O quadro não é exclusivo desse ou daquele presídio. A situação mostra-se similar em todas as unidades da Federação, devendo ser reconhecida a inequívoca falência do sistema prisional brasileiro ${ }^{70}$.

A situação de precariedade já latente no cárcere se torna ainda pior quando enfrentada por um grupo que apresenta necessidades de saúde específicas, como é o caso das mulheres trans. Estas necessidades podem ser divididas em três eixos diferentes: (i) saúde mental ${ }^{71}$; (ii) infecções

69 FERREIRA, Guilherme Gomes; KLEIN, Caio Cesar; GOULART, Vincent Pereira. A Criação de Alas ou Galerias Específicas para LGBTs Presos como 'Política Penitenciária’: contradições e disputas. Revista Sociologia Jurídica, n. 28, p. 21-36, abr. 2019. p. 39.

70 BRASIL. Supremo Tribunal Federal. Arguição de Descumprimento de Preceito Fundamental No 347. Relator: Min. Marco Aurélio Mello. Brasília, 09/09/2015. p. 23-24.

71 Transgender Equality Network Ireland. Speaking from the Margins. Dublin, 2013. 
sexualmente transmissíveis (ISTs) e $\mathrm{HIV}^{72}$ 73; e (iii) procedimentos relacionados ao processo de transição ${ }^{74} 75$.

As pessoas trans apresentam demandas específicas de saúde, as quais decorrem, em grande parte, da sua situação de vulnerabilidade. Assim, tendo em vista se tratar de uma população que possui menos acesso a serviços públicos de saúde quando em liberdade, o encarceramento acaba, por sua vez, por potencializar essa condição, deteriorando ainda mais as condições de saúde desse grupo.

Todavia, há que se ressaltar, desde já, que inexistem dados oficiais que demonstrem com exatidão as demandas ou problemas de saúde da população trans no cárcere. Do mesmo modo, a literatura publicada sobre o tema é bastante escassa. Daí a importância reforçada desta Honorável Corte pautar a temática.

Uma revisão sistemática de estudos realizados em diversos países apontou que a prevalência do HIV nas mulheres trans é de $19,1 \%{ }^{76}$. No Brasil, estudos recentes apontaram números ainda maiores. Uma pesquisa feita na cidade de Porto Alegre, estimou uma prevalência de infecção pelo HIV de $25 \%{ }^{77}$, enquanto uma outra pesquisa, feita no Rio de Janeiro, apontou uma prevalência de $31,2 \%{ }^{78}$.

Contudo, no cárcere, os números são ainda mais altos. Em um estudo realizado com 82 mulheres trans encarceradas na Casa de Detenção, no estado de São Paulo, 78\% das entrevistadas testaram positivo para HIV $(n=64)$. Dentre as que estavam detidas há mais de 6 anos, a incidência chegou em 100\%. Em comparação, a incidência de HIV na população cisgênera era de apenas $17,3 \%{ }^{79}$.

72 CLEMENTS-NOLLE, K. et al. HIV Prevalence, Risk Behaviors, Health Care Use, and Mental Health Status of Transgender Persons: implications for public health intervention. American Journal of Public Health, v. 91, n. 6, p. 915-921, 2001.

73 GUADAMUZ, T. E. et al. HIV Prevalence, Risk Behavior, Hormone Use and Surgical History Among Transgender Persons in Thailand. AIDS and Behavior, 2011, v. 15, n. 3. p. 650-658.

74 ROCON, Pablo Cardozo et al. O que Esperam Pessoas Trans do Sistema Único de Saúde?. Interface (Botucatu) [online]. 2018, vol.22, n.64. p.43-53.

75 PEREIRA, L. B. C.; CHAZAN, A. C. S. O Acesso das Pessoas Transexuais e Travestis à Atenção Primária à Saúde: uma revisão integrativa. Revista Brasileira de Medicina de Família e Comunidade, Rio de Janeiro, 2019, v. 14, n. 41, p. 1795.

76 BARAL, S. D. et al. Worldwide Burden of HIV in Transgender Women: a systematic review and meta-analysis. The Lancet Infectious Diseases, v. 13, n. 3, p. 214-222, mar. 2013.

77 COSTA, A. B. et al. Population-Based HIV Prevalence and Associated Factors in Male to Female Transsexuals from Southern Brazil. Archives of Sexual Behavior, v. 44, n. 44, p. 521-524, 2015.

78 GRINSZTEJN, B. et al. Unveiling of HIV Dynamics Among Transgender Women: a respondent-driven sampling study in Rio de Janeiro, Brazil. The Lancet HIV, v. 3018, n. 17, p. 1-8, 2017.

79 VARELA, D.; TUASON, L.; PROFFITT, M. R.; ESCALEIRA, N.; ALQUEZAR, A.; BUKOWSKI, R. M.; HIV Infection among Brazilian Transvestites in a Prison Population. AIDS PATIENT CARE and STDs, 1996, Volume 10, Number 5. p. 299-302. 
Os altos índices de HIV e demais ISTs possuem relação com o fato de que não raro as mulheres trans, quando colocadas em presídios masculinos, são estupradas pelos outros detentos. Quando não são estupradas, acabam recorrendo ao sexo enquanto "moeda de troca”, para que não sofram outros tipos de violência na prisão e tenham acesso a determinados benefícios ${ }^{80}$.

Em se tratando de um grupo socialmente vulnerável, a violação de direitos que resguardam a dignidade da pessoa humana acaba por aprofundar ainda mais sua repressão social, bem como reforça estigmas sobre uma população marginalizada socialmente.

Isto posto, alguns Estados da América Latina têm adotado boas práticas no que diz respeito ao tratamento de pessoas LGBTQI+ em situação de prisão.

Na Argentina, por exemplo, foi criado, no ano de 2016, através do Boletim Público Normativo $n^{\circ}$ 613, do Diretor Nacional do Serviço Penitenciário Federal, o Programa Específico para Mulheres Trans em Regime de Internação do Serviço Penitenciário Federal, com a finalidade de trazer normas adequadas ao tratamento de mulheres trans privadas de liberdade, dando enfoque aos riscos e necessidades específicas destas pessoas ${ }^{81}$. No ano seguinte, em 2017, a mesma organização aprovou duas iniciativas importantes: a criação do programa Diversidade Sexual e Identidade de Gênero em Contextos de Confinamento, que tinha a finalidade de estimular a coleta de informação, análise e detectar problemas específicos da comunidade LGBTQI+ em situação de prisão, e a publicação da Recomendação $\mathrm{n}^{\circ}$ 842, solicitando que todas as pessoas detidas que declarassem sua orientação sexual ou identidade de gênero fossem consultadas sobre suas acomodações ${ }^{82}$.

Na Colômbia, foram adotadas a Resolução nº 6.349, um regulamento por parte do Ministério da Justiça e do Instituto Nacional Penitenciário e Carcerário (INPEC) sobre a proteção das pessoas LGBTQI+ privadas de liberdade, e a regulamentação por meio da Corte Constitucional sobre o tratamento da população prisional pertencentes às minoridades de identidade sexual. No segundo documento, assegurava-se o respeito às identidades de gênero nas prisões, à integridade física e a

80 BARRIQUELLO, Carolina Andrade; KRAWCZAK, Kaoanne Wolf; STURZA, Janaína Machado. Uma "Moeda de Troca” nas Penitenciárias: o direito à saúde dos transexuais no sistema carcerário brasileiro. Salão do conhecimento, UNIJÚI, jan./out. 2018.

81 Organização não governamental Corpora en Libertad. Solicitação de audiência sobre a "Situação dos Direitos Humanos das Pessoas LGBT+ Privadas de Liberdade nas Américas” dentro o $168^{\circ}$ período ordinário de sessões de CIDH. https://www.ppn.gov.ar/sites/default/files/Informe\%20Audiencia\%20Personas\%20LGBT\%20\%20PRIVADAS\%20 DE\%20LIBERTAD\%20-\%20Corpora\%20en\%20Libertad-\%20.pdf. Acesso em: 1 nov. 2020.

82 Organização não governamental Corpora en Libertad. Solicitação de audiência sobre a "Situação dos Direitos Humanos das Pessoas LGBT+ Privadas de Liberdade nas Américas” dentro o $168^{\circ}$ período ordinário de sessões de CIDH. 
desnecessidade do corte de cabelo destas pessoas, o que resultou na Diretiva Permanente $\mathrm{n}^{0} 00010$, de 2010, pelo INPEC ${ }^{83}$.

Em El Salvador, foi lançada, pelo Ministério da Justiça e Segurança Pública, no ano de 2018, a Política do Ministério da Justiça e Segurança Pública para Atenção à População LGBTQI+, que tinham como eixos centrais a igualdade e a não discriminação, a adoção das devidas diligências, a intervenção imediata e oportuna, o reconhecimento da auto identificação, a equidade, a proteção, o respeito e a confidencialidade ${ }^{84}$.

Na Guatemala, a criação da Política Nacional de Reforma Penitenciária 2014-2024, tem, dentre seus objetivos, o de fortalecer a supervisão dos grupos vulneráveis, com vistas a garantir sua segurança e integridade ${ }^{85}$.

No México, desde 2015, passou-se a coletar dados sobre a população LGBTQI+ por meio de entrevistas realizadas com assistente social já na chegada das pessoas aos centros penitenciários. Neste mesmo ano, houve adoção da Recomendação nº 13/2015 da Comissão de Direitos Humanos do Distrito Federal em razão de agressões físicas realizadas por tutores da Cadeia Preventiva Masculina do Norte contra três mulheres trans e dois homens gays ${ }^{86}$.

A existência de normativa que discipline a matéria não garante a observância de seu conteúdo na prática, mas já representa uma conquista para esta população privada de liberdade.

Partindo da realidade de desrespeito reiterado às garantias de direitos humanos que ocorrem em todo o sistema prisional brasileiro, acrescentando as violações sistemáticas de direitos às quais são submetidas a população LGBTQI+ de maneira geral, é dever do Estado garantir a essa parcela da população em privação de liberdade o respeito à integridade física, psíquica e moral dentro do

83 Organização não governamental Corpora en Libertad. Solicitação de audiência sobre a "Situação dos Direitos Humanos das Pessoas LGBT+ Privadas de Liberdade nas Américas” dentro o $168^{\circ}$ período ordinário de sessões de CIDH. Disponível https://www.ppn.gov.ar/sites/default/files/Informe\%20Audiencia\%20Personas\%20LGBT\%20\%20PRIVADAS\%20 DE\%20LIBERTAD\%20-\%20Corpora\%20en\%20Libertad-\%20.pdf. Acesso em: 1 nov. 2020.

84 Organização não governamental Corpora en Libertad. Solicitação de audiência sobre a "Situação dos Direitos Humanos das Pessoas LGBT+ Privadas de Liberdade nas Américas” dentro o $168^{\circ}$ período ordinário de sessões de CIDH. Disponível em: https:/www.ppn.gov.ar/sites/default/files/Informe\%20Audiencia\%20Personas\%20LGBT\%20\%20PRIVADAS\%20 DE\%20LIBERTAD\%20-\%20Corpora\%20en\%20Libertad-\%20.pdf. Acesso em: 1 nov. 2020.

85 Organização não governamental Corpora en Libertad. Solicitação de audiência sobre a "Situação dos Direitos Humanos das Pessoas LGBT+ Privadas de Liberdade nas Américas” dentro o $168^{\circ}$ período ordinário de sessões de CIDH. Disponível

em: https://www.ppn.gov.ar/sites/default/files/Informe\%20Audiencia\%20Personas\%20LGBT\%20\%20PRIVADAS\%20 DE\%20LIBERTAD\%20-\%20Corpora\%20en\%20Libertad-\%20.pdf. Acesso em: 1 nov. 2020.

86 Organização não governamental Corpora en Libertad. Solicitação de audiência sobre a "Situação dos Direitos Humanos das Pessoas LGBT+ Privadas de Liberdade nas Américas” dentro o $168^{\circ}$ período ordinário de sessões de CIDH. Disponível

em: https://www.ppn.gov.ar/sites/default/files/Informe\%20Audiencia\%20Personas\%20LGBT\%20\%20PRIVADAS\%20 DE\%20LIBERTAD\%20-\%20Corpora\%20en\%20Libertad-\%20.pdf. Acesso em: 1 nov. 2020. 
estabelecimento prisional para que se sinta segura em realizar a autodeclaração, sem qualquer tipo de discriminação ou violência.

Além de considerar as questões de gênero quando da alocação das pessoas privadas de liberdade nos estabelecimentos prisionais, é necessária a capacitação dos funcionários da administração penitenciária e do sistema de justiça em relação às especificidades de identidade de gênero e sexual. Tal capacitação deve ser feita à luz dos diversos instrumentos legais nacionais e de sistemas internacionais de direitos humanos, observando, ainda, a ressocialização inclusiva dos demais detentos, a fim de reduzir a violência física e psicológica que a população trans sofre dentro dos presídios.

Portanto, observamos que os Estados devem criar alas específicas nas instituições masculinas e femininas para atender o público LGBTQI+ e protegê-lo da violência que se institucionalizou nos centros de execução da pena, ação que poderia ser alavancada com a liberação de verbas do fundo penitenciário, bem como a fiscalização da aplicação destes recursos. Não apenas com a finalidade de mera separação específica no cumprimento da pena, mas para possibilitar, também, que o seu direito de visita íntima possa ocorrer sem qualquer obstáculo ao convívio com os demais detentos, uma vez que a segregação interna impossibilita que a população trans possa fazer uso do seu direito de visita sem que sofra represálias ou ameaças dos demais presos, tal como os indivíduos possam desenvolver sua convivência sem obstáculos por preconceitos enraizados em nossa sociedade. Todos estes pontos favorecem para que o direito à visita íntima possa ser concretizado, mitigando o preconceito interno e possibilitando que homens e mulheres trans possam resguardar sua dignidade enquanto cumprem a sua pena.

Por essa razão, a observância da autodeclaração de identidade de gênero e a possibilidade de escolha do tipo de estabelecimento prisional para cumprimento de pena privativa de liberdade que assegure a integridade física, mental e psíquica do indivíduo é essencial para a garantia dos direitos humanos das pessoas trans privadas de liberdade.

\section{Vulnerabilidades sobrepostas}

\section{Va. Gestantes e lactantes privadas de liberdade}

A atenção específica aos direitos de mulheres gestantes, lactantes e em período pós-parto privadas de liberdade justifica-se pelas necessidades particulares e pela sobreposição de vulnerabilidades que este grupo enfrenta.

Mulheres representam minoria numérica no sistema prisional do continente americano, 
correspondendo a aproximadamente $5 \%$ da população prisional brasileira ${ }^{87}$, o que, por si só, dificulta que as políticas públicas e a própria administração prisional levem em conta suas particularidades. Aquelas em período gestacional, de pós-parto ou lactação possuem necessidades ainda mais específicas, o que resulta em tratamento ainda menos favorável, uma vez que o próprio ambiente no qual se encontram privadas de liberdade raramente é pensado para atender sequer sua condição de mulher ${ }^{88}$.

Por isso, o desenvolvimento de conjuntos normativos específicos para este grupo busca enfrentar o tema com atenção às suas peculiaridades, em busca de tratamento igualitário que fortaleça a igualdade de gênero de modo substancial ${ }^{89}$.

Nada obstante, o desenvolvimento de standards específicos para este grupo não deve significar uma defesa ou um incentivo de medidas de encarceramento de mulheres grávidas, lactantes ou em pós-parto. Ao contrário, medidas alternativas à prisão, especialmente para este grupo, são reiteradamente recomendadas por importantes documentos, sendo que, no âmbito internacional, são observadas, por exemplo, as Regras de Bangkok ${ }^{90}$, as Regras de Mandela ${ }^{91}$ e os documentos do Comitê Europeu para Prevenção da Tortura e Penas ou Tratamento Desumanos ou Degradantes

87 BRASIL. Departamento Penitenciário Nacional (DEPEN). Levantamento Nacional de Informações Penitenciárias: Período de julho a dezembro de $2019 . \quad$ Disponível em: https://app.powerbi.com/view?r=eyJrIjoiZWI2MmJmMzYtODA2MC00YmZiLWI4M2ItNDU2ZmIyZjFjZGQ0Iiwi dCI6ImViMDkwNDIwLTQ0NGMtNDNmNy05MWYyLTRiOGRhNmJmZThlMSJ9. Acesso em: 14 out. 2020.

88 COUNCIL OF EUROPE. European Committee for Prevention of Torture and Inhuman or Degrading Treatment or Punishment (CPT). Factsheet: women in prison. CPT/Inf (2018)5 Janeiro de 2018. 'Factsheets' apresentam os standards de proteção a determinados direitos de acordo com o CPT. França: Conselho da Europa, 2018. Disponível em: https://www.coe.int/en/web/cpt/women-in-prison. Acesso em: 5 out. 2020. p. 1.

89 ASSEMBLEIA GERAL DAS NAÇÕES UNIDAS. Escritório das Nações Unidas Sobre Drogas e Crime (UNODC). Regras das Nações Unidas para o Tratamento de Mulheres Presas e Medidas Não Privativas de Liberdade para Mulheres Infratoras (Regras de Bangkok). A/RES/65/229. Suíça: Assembleia Geral da ONU, 2010.

90 ASSEMBLEIA GERAL DAS NAÇÕES UNIDAS. Escritório das Nações Unidas Sobre Drogas e Crime (UNODC). Regras das Nações Unidas para o Tratamento de Mulheres Presas e Medidas Não Privativas de Liberdade para Mulheres Infratoras (Regras de Bangkok). A/RES/65/229. Suíça: Assembleia Geral da ONU, 2010.

91 ASSEMBLEIA GERAL DAS NAÇÕES UNIDAS. Escritório das Nações Unidas Sobre Drogas e Crime (UNODC). Regras Mínimas das Nações Unidas para o Tratamento de Reclusos (Regras de Nelson Mandela). A/RES/70/175. Suíça: Assembleia Geral da ONU, 2015. 
$(\mathrm{CPT})^{92}$. Já no âmbito nacional, o próprio Código de Processo Penal ${ }^{93}$ brasileiro faz recomendações semelhantes.

Nesse ânimo, apresentam-se nesta seção os principais padrões de tratamento aos direitos de mulheres grávidas, lactantes e em pós-parto, privadas de liberdade, recomendados e aplicados, (i) na perspectiva de diálogos entre sistemas, pelos sistemas global e europeu de proteção de direitos humanos; (ii) pelo Sistema Interamericano de Direitos Humanos; (iii) pelo ordenamento jurídico brasileiro.

No sistema global de proteção dos direitos humanos, as Regras Mínimas para o Tratamento de Reclusos, adotadas em 1955 no âmbito das Nações Unidas (Regras de Mandela) ${ }^{94}$, oferecem parâmetros mínimos para proteção do direito de acesso à assistência médica e psicológica para mulheres privadas de liberdade.

De acordo com o artigo 22, o estabelecimento penitenciário deve dispor dos serviços de ao menos um médico qualificado com conhecimento sobre psiquiatria, incluindo-se também a disponibilidade de tratamento psiquiátrico caso seja este o diagnóstico, além de produtos farmacêuticos específicos necessários para os tratamentos adequados, incluindo necessidades odontológicas. Além disso, determina que os serviços médicos prestados no estabelecimento devem manter estreita ligação com sistema de saúde local ou da nação.

A seu tempo, o artigo 23.1 determina que deve haver instalações especiais no próprio estabelecimento prisional para ser possível o tratamento adequado de mulheres grávidas e em pósparto.

Assim, a leitura conjunta dos dispositivos permite a conclusão de que se deve observar as especificidades dos atendimentos médicos e psicológicos oferecidos em estabelecimentos prisionais, para que sejam adequados ao tratamento das pessoas às quais se destinam, o que inclui a situação de mulheres grávidas, em pós-parto ou lactantes.

92 COUNCIL OF EUROPE. European Committee for Prevention of Torture and Inhuman or Degrading Treatment or Punishment (CPT). Factsheet: Women in prison. CPT/Inf (2018)5 Janeiro de 2018. 'Factsheets' apresentam os standards de proteção a determinados direitos de acordo com o CPT. França: Conselho da Europa, 2018. Disponível em: https://www.coe.int/en/web/cpt/women-in-prison. Acesso em: 5 out. 2020. p. 5; COUNCIL OF EUROPE. European Committee for Prevention of Torture and Inhuman or Degrading Treatment or Punishment (CPT). 24 Relatório Geral do CPT. 1680696a9c. O relatório reúne informações acerca das visitas feitas pelo CPT no período de 01/08/2013 e 31/12/2014. França: Conselho da Europa, 2015. Disponível em: https://rm.coe.int/1680696a9c. Acesso em: 5 out. 2020. par. 117.

93 Ver, por exemplo, os artigos 318, inciso IV, e 318-A do Código de Processo Penal brasileiro. (BRASIL. Decreto-lei no 3.689, de 3 de outubro de 1941. Código de Processo Penal. Disponível em: http://www.planalto.gov.br/ccivil_03/Decreto- Lei/Del3689.htm. Acesso em: 29 set. 2020.

94 ASSEMBLEIA GERAL DAS NAÇÕES UNIDAS. Escritório das Nações Unidas Sobre Drogas e Crime (UNODC). Regras Mínimas das Nações Unidas para o Tratamento de Reclusos (Regras de Nelson Mandela). A/RES/70/175. Suíça: Assembleia Geral da ONU, 2015. 
Nessa toada, também as Regras das Nações Unidas para o Tratamento de Mulheres Presas e Medidas Não Privativas de Liberdade para Mulheres Infratoras (Regras de Bangkok) ${ }^{95}$ preveem normas que preceituam tratamento específico com relação: (i) aos cuidados com a higiene; (ii) ao suporte e atendimento médico adequado e especializado; (iii) à alimentação; e (iv) às condições mínimas a serem observadas no momento do trabalho de parto e o período imediatamente posterior.

Quanto aos cuidados com a salubridade, a Regra 5 estabelece que as instalações e acomodações das mulheres presas devem satisfazer suas necessidades específicas de higiene, incluindo o suprimento regular de água para cuidados pessoais, em particular tratando-se de mulheres gestantes e lactantes.

No que se refere ao acesso à saúde, a Regra 25.2 prevê que, sobretudo as mulheres que engravidaram em decorrência de abuso sexual, devem receber orientação, atendimento e aconselhamento médicos apropriados, compreendendo, nesse eixo, auxílio psicológico e assistência jurídica adequados. Além disso, a Regra 25.3 dispõe que o monitoramento e inspeção das condições do cárcere deverão ser efetuados por órgãos e/ou grupos que possuam mulheres entre seus membros. A Regra 39, ainda, aborda de forma destacada que, em relação às adolescentes gestantes, recaem os mesmos cuidados médicos destinados às grávidas adultas, inclusive o monitoramento por médico especializado, visto que a pouca idade pode acarretar maiores riscos de complicações durante a gestação.

Relativamente à alimentação, há disposição expressa na Regra 48.1 de que mulheres gestantes ou lactantes recebam orientação de dieta a partir de um programa elaborado e revisto por um profissional de saúde qualificado. Ademais, o mesmo dispositivo impõe que seja ofertada uma alimentação gratuita, pontual e adequada, bem como um ambiente que proporcione exercícios físicos regulares a essas mulheres. Outra disposição que garante maior especificidade quanto aos cuidados médicos e nutricionais, em especial às mulheres em estado puerperal (que tenham recentemente dado à luz), é a Regra 48.3, que dispõe que as necessidades especiais daquelas que não estejam com seus filhos no ambiente prisional sejam incluídas em programas de tratamento.

No que concerne às condições mínimas que devem ser verificadas no momento do parto, a Regra 24 é incisiva no sentido de coibir a utilização de instrumentos de contenção nas mulheres em trabalho de parto, durante o parto ou no período imediatamente posterior.

95 ASSEMBLEIA GERAL DAS NAÇÕES UNIDAS. Escritório das Nações Unidas Sobre Drogas e Crime (UNODC). Regras das Nações Unidas para o Tratamento de Mulheres Presas e Medidas Não Privativas de Liberdade para Mulheres Infratoras (Regras de Bangkok). A/RES/65/229. Suíça: Assembleia Geral da ONU, 2010. 
Sobre esse último aspecto, relevante salientar que o Comitê de Ministros do Conselho da Europa, por intermédio da Recomendação Rec(2006)2 aos Estados Membros sobre as Regras Penitenciárias Europeias ${ }^{96}$, emitida em 2006, editou dispositivo que garante às reclusas o direito preferencial de dar à luz fora da prisão, não obstando, contudo, que as autoridades estatais estejam obrigadas a prestar assistência e proporcionar infraestrutura necessária caso o bebê venha a nascer no ambiente da prisão (recomendação 34.3).

A título de comparação, no âmbito do Conselho da Europa, o documento "Women in Prison”, desenvolvido pelo Comitê Europeu de Prevenção à Tortura e a Penas ou Tratamentos Desumanos ou Degradantes (CPT) em 2018, também trata de provisões a respeito do direito à saúde de mulheres privadas de liberdade, defendendo que o acesso à saúde deste grupo deve permanecer equivalente àquele usufruído pela população no geral ${ }^{97}$, pois a condição de privação de liberdade não deve ser fator de impacto no gozo de tal direito.

Destacam-se especialmente as previsões de acesso adequado a: (i) tratamento de saúde feminino de caráter preventivo, (ii) medicamentos que eram consumidos pelas mulheres antes de seu encarceramento, (iii) pílulas contraceptivas e procedimentos de aborto nos casos em que são permitidos; e (iv) tratamento psicológico com abordagem multifacetada nos casos em que há transtornos de personalidade e comportamentais não passíveis de transferência para hospitais psiquiátricos ${ }^{98}$. São medidas que não devem deixar de ser asseguradas às mulheres em decorrência da situação de privação de liberdade e que, por sua própria natureza e condição, assumem especial relevância nos casos de mulheres grávidas, lactantes ou em pós-parto.

Especificamente em relação às obrigações estatais no que tange à alimentação de mulheres grávidas, lactantes ou em pós-parto, o documento indica a importância de ofertar uma dieta com alto teor de proteína e rica em frutas e vegetais ${ }^{99}$. Além disso, o Relatório do CPT sobre o sistema prisional

96 COUNCIL OF EUROPE. Committee of Ministers, Recommendation Rec(2006)2 of the Committee of Ministers to Member States on the European Prison Rules. 11 January 2006, $\operatorname{Rec}(2006) 2$. Disponível em: https://www.refworld.org /docid/43f3134810.html. Acesso em: 30 set. 2020.

97 COUNCIL OF EUROPE. European Committee for Prevention of Torture and Inhuman or Degrading Treatment or Punishment (CPT). Factsheet: women in prison. CPT/Inf(2018)5 Janeiro de 2018. 'Factsheets' apresentam os standards de proteção a determinados direitos de acordo com o CPT. França: Conselho da Europa, 2018. Disponível em: https://www.coe.int/en/web/cpt/women-in-prison. Acesso em: 5 out. 2020. p. 4.

98 COUNCIL OF EUROPE. European Committee for Prevention of Torture and Inhuman or Degrading Treatment or Punishment (CPT). Factsheet: women in prison. CPT/Inf(2018)5 Janeiro de 2018. 'Factsheets' apresentam os standards de proteção a determinados direitos de acordo com o CPT. França: Conselho da Europa, 2018. Disponível em: https://www.coe.int/en/web/cpt/women-in-prison. Acesso em: 5 out. 2020. p. 4.

99 COUNCIL OF EUROPE. European Committee for Prevention of Torture and Inhuman or Degrading Treatment or Punishment (CPT). Factsheet: women in prison. CPT/Inf(2018)5 Janeiro de 2018. 'Factsheets' apresentam os standards de proteção a determinados direitos de acordo com o CPT. França: Conselho da Europa, 2018. Disponível em: https://www.coe.int/en/web/cpt/women-in-prison. Acesso em: 5 out. 2020. p. 5. 
romeno fez importantes recomendações a respeito da alimentação de lactantes privadas de liberdade, indicando que devem receber suplemento dietético de acordo com as diretrizes para esta categoria de mulheres ${ }^{100}$.

Já em relação às condições mínimas que o Estado deve garantir durante o trabalho de parto e o parto em si, o CPT indica como boa prática dos Estados-membros do Conselho da Europa o fato de, em sua maioria, garantirem que mulheres grávidas privadas de liberdade tenham seus filhos fora do estabelecimento prisional. Ainda assim, chama atenção para o dever estatal de garantir que tais mulheres não sejam algemadas ou presas de qualquer forma a camas ou outras mobílias durante exames ginecológicos e trabalho de parto, o que pode resultar em tratamento desumano e degradante ${ }^{101}$.

Por fim, no que diz respeito às condições materiais das instalações penitenciárias, destacase, em diálogo com o Sistema Europeu, o julgamento do caso Korneykova e Korneykov v. Ucrânia ${ }^{102}$, no qual a primeira requerente foi detida em prisão preventiva quando estava no quinto mês de gravidez, dando à luz a um bebê (o segundo requerente) durante o período de detenção. Além da violação ao artigo 3 da Convenção Europeia de Direitos Humanos (proibição da tortura) devido ao uso de correntes no momento do parto, a Corte Europeia reconheceu um efeito cumulativo de desnutrição da mãe, inadequação das condições sanitárias e de higiene para ela e seu filho e insuficiência de caminhadas ao ar livre, o que teria ocasionado e induzido sofrimento físico e angústia emocional equivalentes a um tratamento desumano e degradante das duas vítimas ${ }^{103}$.

No SIDH, diversos dispositivos normativos e interpretativos têm como objeto proteger as mulheres privadas de liberdade e aquelas em período de gravidez ou lactância, embora não haja diálogo tão profundo acerca das duas categorias.

100 COUNCIL OF EUROPE. European Committee for Prevention of Torture and Inhuman or Degrading Treatment or Punishment (CPT). Rapport au Gouvernement de la Roumanie relatif à la visite effectuée en Roumanie per le CPT. CPT/Inf(2015)31 Junho 2014. O relatório diz respeito à visita feita pelo CPT à Romênica no período de 5 a 17 de junho de 2014. França: Conselho da Europa, 2018. Disponível em: https://rm.coe.int/1680697a4a. Acesso em: 5 out. 2020. para 99.

101 COUNCIL OF EUROPE. European Committee for Prevention of Torture and Inhuman or Degrading Treatment or Punishment (CPT). $\mathbf{1 0}^{\circ}$ Relatório Geral do CPT. 1680696a74. O relatório reúne informações acerca das visitas feitas pelo CPT no período de 01/01 a 31/12/1999. França: Conselho da Europa, 2000. Disponível em: https://rm.coe.int/1680696a74. Acesso em: 5 out. 2020. para. 27.

${ }^{102}$ COUNCIL OF EUROPE. European Court of Human Rights. Sentença no processo n ${ }^{\circ}$ 56660/12. Korneykova e Korneykov Vs. Ucrânia, 24 de junho de 2016. Disponível em: https://hudoc.echr.coe.int/eng\#\{\%22itemid\%22:[\%22001-161543\%22]\}. Acesso em: 5 out. 2020.

103 COUNCIL OF EUROPE. European Court of Human Rights. Sentença no processo n ${ }^{\circ} 56660 / 12$. Korneykova e Korneykov Vs. Ucrânia, 24 de junho de 2016. Disponível em: https://hudoc.echr.coe.int/eng\#\{\%22itemid\%22:[\%22001-161543\%22]\}. Acesso em: 5 out. 2020. par. 140-148. 
Neste sentido, a CADH, em seu art. 4.5, proíbe a aplicação da pena de morte em especial à mulher em estado de gravidez. Ademais, a Declaração Americana de Direitos e Deveres do Homem (DADH), em seu art. $7^{\circ}$, prevê que toda mulher em estado de gravidez ou em época de lactação, assim como toda criança, tem direito à proteção, cuidados e auxílios especiais, no âmbito dos direitos de proteção à maternidade e à infância. A Convenção de Belém do Pará (CBP), ainda, prevê em seu art. $9^{\circ}$ a condição de gestante ou de privação de liberdade como um eixo interpretativo de vulnerabilidade para a aplicação de medidas, as quais são dever do Estado, para erradicar a violência contra a mulher. Assim, a CIDH destaca que, conforme este artigo, a CBP ressalta a situação de vulnerabilidade da gravidez e puérperas ${ }^{104}$.

Ademais, aprovados pela CIDH em seu $131^{\circ}$ Período de Sessões mediante a Resolução No. 1/08, os Princípios e Boas Práticas para a Proteção das Pessoas Privadas de Liberdade nas Américas fixam o que a CIDH considera como as principais normas internacionais de proteção relativas às pessoas privadas de liberdade.

Dentro do princípio II de igualdade e não-discriminação, há a previsão de que não serão consideradas discriminatórias as medidas que se destinem a proteger exclusivamente os direitos das mulheres, em especial as mulheres grávidas ou as mães lactantes.

O princípio X, concernente à saúde, afirma que mulheres e meninas privadas de liberdade deverão ter acesso a atendimento médico especializado, “que corresponda a suas características físicas e biológicas e que atenda adequadamente a suas necessidades em matéria de saúde reprodutiva”105, como ginecológico e pediátrico antes, durante e depois do parto, que não deverá ser realizado nos locais de privação de liberdade, e sim em hospitais ou estabelecimentos específicos.

Quanto a alojamento, condições de higiene e vestuário, é previsto às pessoas privadas de liberdade: (i) espaço suficiente, com exposição diária à luz natural, ventilação e calefação apropriadas, segundo as condições climáticas do local de privação de liberdade; (ii) cama individual, roupa de cama adequada e demais condições indispensáveis para o descanso noturno, levando em conta as necessidades especiais das mulheres grávidas ou mães lactantes; (iii) acesso a instalações sanitárias higiênicas e em número suficiente, que assegurem sua privacidade e dignidade, com artigos indispensáveis às necessidades sanitárias próprias de seu sexo.

104 CIDH. Anexo 1. Principales Estándares y Recomendaciones en Materia de Violencia y Discriminación Contra Mujeres, Niñas y Adolescentes. OEA/Ser.L/V/II. Doc. 233. 14 noviembre 2019, p. 7.

105 CIDH. Princípios e Boas Práticas para a Proteção das Pessoas Privadas de Liberdade nas Américas. Princípio X. Disponível em: http://www.oas.org/pt/cidh/mandato/Basicos/principiosPPL.asp. Acesso em: 1 out. 2020. 
Por fim, quanto ao princípio XXII, acerca do regime disciplinar, serão proibidas as medidas ou sanções de isolamento em celas de castigo, sendo estritamente proibidas as medidas de isolamento das mulheres grávidas; das mães que convivam com os filhos no interior dos estabelecimentos de privação de liberdade; e das crianças privadas de liberdade ${ }^{106}$.

Da mesma forma, os estabelecimentos de privação de liberdade para mulheres e meninas deverão dispor de instalações especiais, bem como de pessoal e recursos apropriados para o tratamento das mulheres e meninas grávidas e das que tenham recém dado à luz.

Nesse sentido, o encarceramento de mães ou mulheres grávidas deve ser o último recurso, priorizando medidas não privativas de liberdade ${ }^{107}$. Além de recomendações em informes por países $^{108}$, a CIDH também preconiza, conforme diretrizes do Alto Comissariado das Nações Unidas para os Refugiados (ACNUR), que mulheres grávidas migrantes ou refugiadas detidas não devem permanecer em condições carcerárias ${ }^{109}$.

Já no que diz respeito à informação, o relatório da CIDH sobre "acesso a serviços de saúde materna desde uma perspectiva de direitos humanos”110, ainda que não trate expressamente sobre pessoas privadas de liberdade, conceitua a falta de informação em matéria reprodutiva como barreira para acesso à saúde das mulheres, porque as impede de tomar decisões livres e fundamentadas ${ }^{111}$. No mesmo sentido, o acesso à informação no que tange à saúde materna também inclui o direito de ter informações sobre o risco de emergências obstétricas e as possíveis consequências de determinada escolha médica ${ }^{112}$.

Do mesmo modo, tendo em vista a situação de pandemia da COVID-19, a CIDH, em sua resolução 01/2020, previu expressamente que os Estados devem adotar medidas para enfrentar a aglomeração nas unidades de privação da liberdade, inclusive avaliar a determinação de medidas alternativas à privação da liberdade, dando prioridade às populações com maior risco de saúde frente

${ }^{106}$ CIDH. Princípios e Boas Práticas para a Proteção das Pessoas Privadas de Liberdade nas Américas. Disponível em: http://www.oas.org/pt/cidh/mandato/Basicos/principiosPPL.asp. Acesso em: 1 out. 2020.

${ }^{107} \mathrm{CIDH}$. Informe sobre Medidas Dirigidas a Reducir el Uso de la Prisión Preventiva en las Américas. OEA/Ser.L/V/II.163 Doc. 105, 3 julio 2017, p. 139.

${ }^{108} \mathrm{CIDH}$. Informe de la Comisión Interamericana de Derechos Humanos sobre la Situación de las Personas Privadas de Libertad en Honduras. OEA/Ser.L/V/II.147 Doc. 6., 18 marzo 2013, p. 37.

109 CIDH. Situación de Derechos Humanos de Familias, Niños, Niñas y Adolescentes no Acompañados Refugiados y Migrantes en los Estados Unidos de América. OAS/Ser.L/V/II.155 Doc. 1624 julio 2015, p. 47.

110 OEA. Acceso a Servicios de Salud Materna desde una Perspectiva de Derechos Humanos. OEA/Ser.L/V/II. Doc. 69, 7 junho 2010.

111 OEA. Acceso a Servicios de Salud Materna desde una Perspectiva de Derechos Humanos. OEA/Ser.L/V/II. Doc. 69, 7 junho 2010, p. 10.

112 OEA. Acceso a Servicios de Salud Materna desde una Perspectiva de Derechos Humanos. OEA/Ser.L/V/II. Doc. 69, 7 junho 2010, p. 26. 
a um eventual contágio pela COVID-19, principalmente os idosos e mulheres grávidas ou com filhos lactentes.

Em adição, também recomenda adequar as condições de detenção das pessoas privadas de liberdade, particularmente no que se refere à alimentação, à saúde, ao saneamento e às medidas de quarentena, para impedir o contágio intramuros pela COVID-19, garantindo em particular que todas as unidades contem com atenção médica ${ }^{113}$.

Dentre os casos analisados pela Corte IDH, há três que estão expressa e diretamente relacionados com situações de mulheres grávidas ou lactantes privadas de liberdade.

No caso, Miguel Castro Castro vs. Peru, julgado em 2006, a Corte entendeu que o Estado peruano violou o direito à integridade pessoal dos privados de liberdade do pavilhão 1A (pavilhão feminino) e 4B (pavilhão masculino) do presídio Miguel Castro Castro, os quais foram alvo de violenta ação armada de agentes públicos, no período de 6 a 9 de maio de 1992.

Dentre as mulheres mantidas no pavilhão 1A, foram identificadas três mulheres grávidas, com cinco, sete e oito meses de gestação. A Corte relata, em dois momentos, que todas as mulheres privadas de liberdade deste pavilhão, inclusive as grávidas, foram obrigadas a fugir dos ataques armados, arrastando-se de bruços, coladas ao chão ${ }^{114}$. Destaca, também, o sofrimento mental e psicológico adicional que elas sofreram, em razão do medo pela integridade física de seus bebês ${ }^{115}$. Essas três mulheres, posteriormente, deram à luz aos seus filhos, porém "não receberam atendimento médico até serem levadas ao hospital para o parto. [...] [uma delas] não recebeu atendimento médico pós-parto ${ }^{116 ”}$. Por fim, é mencionada a dificuldade criada pelo Estado, para que as mulheres privadas de liberdade mães pudessem conversar regularmente com os seus filhos, o que causou mais sofrimento psicológico a essas mães ${ }^{117}$.

Ao decidir pela concessão de medidas provisórias em relação ao Centro Penitenciário da Região Andina, na Venezuela, em 2012, a Corte menciona a existência de feridos, dentre eles,

113 CIDH. Pandemia e Direitos Humanos Nas Américas. Resolução 1/2020. Disponível em: https://www.oas.org/pt/cidh/decisiones/pdf/Resolucao-1-20-pt.pdf. Acesso em: 1 set. 2020.

114 CORTE IDH. Presídio Miguel Castro Castro Vs. Peru. Sentença Série C nº 160 de 25 de novembro de 2006, para. 290 e 298.

115 CORTE IDH. Presídio Miguel Castro Castro Vs. Peru. Sentença Série C nº 160 de 25 de novembro de 2006, para. 292.

116 CORTE IDH. Presídio Miguel Castro Castro Vs. Peru. Sentença Série C nº 160 de 25 de novembro de 2006 , para. 197.57.

117 CORTE IDH. Presídio Miguel Castro Castro Vs. Peru. Sentença Série C nº 160 de 25 de novembro de 2006, para. 197.56 e 330 . 
mulheres que teriam abortado em razão das condições inadequadas as quais estavam submetidas ${ }^{118} \mathrm{e}$, de forma genérica, enfatiza:

[...] la obligación de los Estados de tomar en consideración la atención especial que deben recibir las mujeres privadas de libertad embarazadas y en lactancia durante su detención. Asimismo, es deber del Estado proteger a las mujeres contra toda forma de discriminación y violencia, más aún cuando se encuentran bajo la custodia estatal, razón por la cual deben estar separadas de los hombres y ser vigiladas por personal femenino ${ }^{119}$.

No caso Gelman vs. Uruguai, que versa sobre o desaparecimento forçado de mulher grávida, imposição de realização de parto em centro clandestino de detenção e violação dos direitos da criança, que teve sua identidade subtraída e substituída, a Corte entende que:

[...] o estágio de gravidez de María Claudia García quando foi detida constituía uma condição de particular vulnerabilidade, que implicou numa violação diferenciada em seu caso [...] Os fatos do caso revelam uma particular concepção do corpo da mulher que atenta contra sua livre maternidade, o que forma parte essencial do livre desenvolvimento da personalidade das mulheres ${ }^{120}$.

Neste caso, a Corte também menciona os danos psicológicos causados à mãe, em razão de temor pela segurança de sua filha:

Os fatos lhe causaram danos e sofrimentos físicos e psicológicos e constituem uma violação de tal magnitude que deve ser qualificada como a mais grave forma de violação de sua integridade psíquica em função dos sentimentos de grave angústia, desespero e medo que pôde experimentar ao permanecer com sua filha em um centro clandestino de detenção, onde usualmente se escutavam as torturas causadas a outros detidos somado ao fato de não saber qual seria o seu destino quando fossem separadas, assim como de poder ter previsto seu destino fatal ${ }^{121}$.

Nesses três casos, a Corte indicou o contexto de vulnerabilidade de mulheres encarceradas, destacando que a situação de gravidez ou lactância acentua essa vulnerabilidade e demanda, portanto, medidas protetivas adicionais do Estado, uma vez que qualquer dano praticado contra a mulher, nesta situação, pode se reverter em dano à criança.

Os casos retratam, ademais, exemplos de situações em que a vida da mulher privada de liberdade estava em extremo perigo. Dessa forma, a Corte, em suas decisões, expõe de maneira mais genérica a obrigação dos Estados em proteger e garantir a vida dessas mulheres. Não há menção sobre obrigações mais específicas, com relação à vestuário, alimentação, estrutura de acolhimento e atendimento gestacional e após o parto.

${ }^{118}$ CORTE IDH. Assunto Centro Penitenciário da Região Andina. Resolução de medida provisória de 06 de setembro de 2012, para. 2, d, XIII.

${ }^{119}$ CORTE IDH. Assunto Centro Penitenciário da Região Andina. Resolução de medida provisória de 06 de setembro de 2012, par. 14.

${ }^{120}$ CORTE IDH. Gelman Vs. Uruguai. Sentença Série $C \mathrm{n}^{\circ} 221$ de 24 de fevereiro de 2011, par. 97.

${ }^{121}$ CORTE IDH. Gelman Vs. Uruguai. Sentença Série C n 221 de 24 de fevereiro de 2011, par. 98. 
O que fica evidente, por outro lado, é a necessidade de proteção desse ser humano, que por ser mulher e estar grávida, fica exposta, de maneira diferenciada e acentuada, ao ambiente carcerário. Qualquer dano ou exposição a perigo causado a ela representa uma gravidade maior, em razão do temor e da angústia gerados na mãe e na possibilidade de implicar em violação de direitos da criança, como ocorrido no caso Gelman Vs. Uruguai, em que Maria Macarena Gelman Garcia teve seus direitos "ao reconhecimento da personalidade jurídica, à vida, à integridade pessoal, à liberdade pessoal, à família, ao nome, aos direitos da criança e à nacionalidade”122 violados.

No Brasil, há uma discrepância extremamente importante de ser ressaltada, que diz respeito entre as leis que regulamentam o sistema carcerário e o que é realmente observado. Além disso, é expressiva a hipertrofia das prisões brasileiras, sendo a superlotação um fato corriqueiro. De acordo com o INFOPEN Mulheres, publicado em 2018, a média brasileira de taxa de ocupação das unidades femininas era 133\%, sendo que nos estados brasileiros Goiás e Amapá, essa taxa chegou, respectivamente, a $318 \%$ e $469 \%{ }^{123}$.

Como o sistema penitenciário brasileiro foi construído de acordo com as demandas masculinas, falta a devida adaptação desses locais para o público feminino. É possível afirmar, assim, que as necessidades das mulheres grávidas, lactantes e pós-parto privadas de liberdade também são negligenciadas. Consoante ao que já havia sido demonstrado no Relatório sobre mulheres encarceradas no Brasil de $2007^{124}$, percebe-se, no país, uma omissão por parte dos poderes públicos, que ignoram as especificidades decorrentes da questão de gênero, as quais exigem do Estado uma atuação proativa.

Para ilustrar a realidade nacional que se espalha pela região, o relatório Mulheres, Meninas e Privação de Liberdade no Rio de Janeiro, realizado pelo Mecanismo Estadual de Prevenção e Combate à Tortura do Rio de Janeiro (MEPCT/RJ), apresenta informações expressivas acerca do tratamento oferecido nas prisões. Na Penitenciária Talavera Bruce, os uniformes das presas não estavam em condições adequadas e os pesquisadores foram informados que somente as camisas eram fornecidas pela unidade ${ }^{125}$.

122 CORTE IDH. Gelman Vs. Uruguai. Sentença Série C nº 221 de 24 de fevereiro de 2011, par. 312.3.

123 BRASIL. Ministério da Justiça e Segurança Pública. Levantamento Nacional de Informações Penitenciárias INFOPEN Mulheres (2a ed.). Brasília, 2018.

124 CENTRO PELA JUSTIÇA E CIDADANIA et al. Relatório sobre Mulheres Encarceradas no Brasil. 2007. [Internet]. Disponível em: https://carceraria.org.br/wp-content/uploads/2013/02/Relato\%CC\%81rio-para-OEAsobre-Mulheres-Encarceradas-no-Brasil-2007.pdf. Acesso em: 30 de set. 2020.

125 Mecanismo Estadual de Prevenção e Combate à Tortura do Rio de Janeiro, 2016. Mulheres, Meninas e Privação de Liberdade no Rio de Janeiro. [online] Rio de Janeiro. p. 41. Disponível em: http://piaui.folha.uol.com.br/lupa/wpcontent/uploads/2016/03/Mulheres-Meninas-e-Privação-de-Liberdade-no-Rio-de-Janeiro-010316.pdf. Acesso em: 23 set. 2020. 
Ainda nesse local, as gestantes afirmaram que após o jantar, servido às $17 \mathrm{~h}$, não recebiam mais nenhum tipo de alimentação, além de não haver fornecimento de água potável para consumo ${ }^{126}$. A própria nutricionista da penitenciária relatou, sobre um possível cardápio especial para as gestantes, que “ainda não tinha pensado sobre isso" ${ }^{27}$. Na Cadeia Pública Joaquim Ferreira de Souza, a situação não é diferente, visto que as apenadas relataram que a última refeição do dia era fornecida às $16 \mathrm{~h}^{128}$.

A precária assistência às mulheres presas também é resultado da visitação pela família menos frequente quando comparadas aos números referentes aos homens presos. De acordo com o INFOPEN Mulheres, nos estabelecimentos masculinos, a média de visitas realizadas por pessoa é de 7.8, a qual cai para 5.9 nos estabelecimentos femininos ${ }^{129}$. Isso significa que as apenadas dependem exclusivamente do que lhes é fornecido pela unidade e, acima de tudo, que são excluídas até do seu círculo familiar, o que dificulta ainda mais a gestação e a maternidade no cárcere e as deixa ainda mais vulneráveis. Na Cadeia Pública Joaquim Ferreira de Souza, por exemplo, a situação é tão crítica que as presas que não recebem visitas ficam totalmente desassistidas ${ }^{130}$.

No ponto, oportuno mencionar que, diante da extrema precarização das condições do cárcere, os itens previstos na "sacola” ou "jumbo" - termos utilizados para designar o conjunto de alimentos, produtos de higiene, roupas e demais pertences permitidos pela instituição prisional e entregues às detentas em dias autorizados ou durante os horários de visita - integram o próprio direito à assistência das mulheres encarceradas. Isso porque, não obstante o notório dever estatal em prover esses itens de maneira ampla e suficiente, o que se vê, na prática, é o completo desamparo daquelas que não recebem assistência externa/familiar, conforme exposto anteriormente. A situação é ainda mais grave no que tange às lactantes, gestantes ou em estado puerperal, visto que o fornecimento de produtos de higiene e vestuário pelo próprio Estado, que já é deficitário e de baixa qualidade, deixa de atender às necessidades ainda mais específicas dessas mulheres.

${ }^{126}$ Mecanismo Estadual de Prevenção e Combate à Tortura do Rio de Janeiro, 2016. Mulheres, Meninas e Privação de Liberdade no Rio de Janeiro. [online] Rio de Janeiro. p. 41. Disponível em: http://piaui.folha.uol.com.br/lupa/wpcontent/uploads/2016/03/Mulheres-Meninas-e-Privação-de-Liberdade-no-Rio-de-Janeiro-010316.pdf. Acesso em: 23 set. 2020.

127 Mecanismo Estadual de Prevenção e Combate à Tortura do Rio de Janeiro, 2016. Mulheres, Meninas e Privação de Liberdade no Rio de Janeiro. [online] Rio de Janeiro. p. 40. Disponível em: http://piaui.folha.uol.com.br/lupa/wpcontent/uploads/2016/03/Mulheres-Meninas-e-Privação-de-Liberdade-no-Rio-de-Janeiro-010316.pdf. Acesso em: 23 set. 2020.

128 Mecanismo Estadual de Prevenção e Combate à Tortura do Rio de Janeiro, 2016. Mulheres, Meninas e Privação de Liberdade no Rio de Janeiro. [online] Rio de Janeiro. p. 41. Disponível em: http://piaui.folha.uol.com.br/lupa/wpcontent/uploads/2016/03/Mulheres-Meninas-e-Privação-de-Liberdade-no-Rio-de-Janeiro-010316.pdf. Acesso em: 23 set. 2020.

129 BRASIL. Ministério da Justiça e Segurança Pública. Levantamento Nacional de Informações Penitenciárias INFOPEN Mulheres (2a ed.). Brasília, 2018.

130 Mecanismo Estadual de Prevenção e Combate à Tortura do Rio de Janeiro, 2016. Mulheres, Meninas E Privação De Liberdade No Rio De Janeiro. [online] Rio de Janeiro. p. 51. 
Ainda, um dos problemas mais graves está relacionado ao exercício do direito à saúde. Uma das presas mencionadas na obra de Queiroz também denuncia esse problema: "Eu, por exemplo, estava grávida. Perdi meu filho faz dez dias, sangrei feito porco e ninguém fez nada, não vi um médico. Agora, tô aqui cheia de febres. Vai ver o corpinho tá apodrecendo dentro de mim”131.

Entre 2012 e 2014, pesquisadores da Fundação Oswaldo Cruz produziram um estudo ${ }^{132}$ que objetivou traçar o perfil de mulheres que viviam junto com os filhos em prisões femininas brasileiras, além de indicar a realidade encontrada nesses lugares quanto ao tratamento da gestação e ao parto no decorrer do encarceramento, em análises realizadas com a colaboração de 241 mães detentas. De acordo com os autores, constatou-se que:

No momento da prisão, 89\% das mulheres já estavam grávidas e dois terços não desejou a gravidez atual. O acesso à assistência pré-natal foi inadequado para 36\% das mães. Durante o período de hospitalização $15 \%$ referiram ter sofrido algum tipo de violência (verbal, psicológica ou física). O atendimento recebido foi considerado excelente por apenas $15 \%$ das mães. Foi baixo o suporte social/ familiar recebido e o uso de algemas na internação para o parto foi relatado por mais de um terço das mulheres. Piores condições da atenção à gestação e ao parto foram encontradas para as mães encarceradas em comparação às não encarceradas, usuárias do SUS ${ }^{133}$.

Além disso, o estudo também foca em questões como o transporte utilizado para a locomoção das gestantes, o tipo de parto e a recepção de familiares ou amigos. Destaca-se que a possibilidade de ter um acompanhante foi em apenas 3\% dos casos, o que contraria o disposto no art. 19-J da Lei $n^{0} 11.108 / 05^{134}$, que assegura a presença de um acompanhante da escolha da paciente em trabalho de parto, durante o parto e no pós-parto. Ainda, em 16\% dos casos, as mulheres alegaram o sofrimento de maus-tratos ou violência, tanto verbal como psicológica, por parte dos profissionais da saúde, e, em 14\% dos casos, pelos guardas ou agentes penitenciários ${ }^{135}$.

A demora no transporte também é um fator a ser exposto. Na Penitenciária Talavera Bruce, as apenadas relataram que existe uma espera de, em média, 12 horas entre a saída da unidade, a

131 QUEIROZ, Nana. Presos que Menstruam. 9a ed. Rio de Janeiro: Editora Record, 2018, p. 186.

132 LEAL, Maria do Carmo et al. Nascer na Prisão: gestação e parto atrás das grades no Brasil. Ciência \& Saúde Coletiva [online]. 2016, vol.21, n.7, pp. 2061-2070. Disponível em: https://www.scielo.br/scielo.php?pid=S1413$81232016000702061 \&$ script=sci abstract\&tlng=pt. Acesso em: 16 out. 2020.

133 LEAL, Maria do Carmo et al. Nascer na Prisão: gestação e parto atrás das grades no Brasil. Ciência \& Saúde Coletiva [online]. 2016, vol.21, n.7, pp. 2061-2070. Disponível em: https://www.scielo.br/scielo.php?pid=S141381232016000702061\&script=sci_abstract\&tlng=pt. Acesso em: 16 out. 2020.

134 BRASIL. Lei n 11.108, de 7 de abril de 2005. Altera a Lei n ${ }^{\circ}$ 8.080, de 19 de setembro de 1990, para garantir às parturientes o direito à presença de acompanhante durante o trabalho de parto, parto e pós-parto imediato, no âmbito do Sistema Único de Saúde - SUS. Diário Oficial da União [internet]. Brasília; 2005. Disponível em: http://www3.dataprev.gov.br/sislex/paginas/42/2005/11108.htm. Acesso em: 30 set. 2020.

135 LEAL, Maria do Carmo et al. Nascer na Prisão: gestação e parto atrás das grades no Brasil. Ciência \& Saúde Coletiva [online]. 2016, vol.21, n.7, pp. 2061-2070. Disponível em: https://www.scielo.br/scielo.php?pid=S141381232016000702061\&script=sci_abstract\&tlng=pt. Acesso em: 16 out. 2020. 
passagem pela Unidade de Pronto Atendimento (UPA) e a chegada à maternidade ${ }^{136}$. No Brasil, existem diversos relatos que comprovam o uso de algemas durante o transporte e o parto das presas, além dos casos em que o parto ocorre nas próprias penitenciárias, sem auxílio médico ${ }^{137}$. Quanto ao uso de algemas, verifica-se a presença de normas que proíbem o uso de instrumentos restritivos nas situações citadas acima, como as regras 47 e 48 das Regras de Mandela, a regra 24 das Regras de Bangkok e o artigo 292, parágrafo único, do Código de Processo Penal brasileiro, o qual, por sua relevância, deve ser citado:

Artigo 292. Parágrafo único. É vedado o uso de algemas em mulheres grávidas durante os atos médico-hospitalares preparatórios para a realização do parto e durante o trabalho de parto, bem como em mulheres durante o período de puerpério imediato ${ }^{138}$.

Quanto ao parto propriamente dito, diversas violações de direitos são percebidas. Dentre os abusos estão: partos dentro de celas ${ }^{139}$, estabelecimentos prisionais sem assistência médica, violência obstétrica e maus-tratos. No Hospital Municipal Albert Schweitzer, no Rio de Janeiro, por exemplo, que atende presas da Penitenciária Talavera Bruce, a violência obstétrica parece ser recorrente. No Relatório Anual do Mecanismo Estadual de Prevenção e Combate à Tortura do Rio de Janeiro (MEPCT/RJ), foram expostas situações em que o agente penitenciário presente na sala de parto estava em frente à gestante com fuzil em mãos, uso de ocitocina (acelerador para o parto) sem a autorização da gestante, médicos se ausentando da sala logo no início do parto, afirmando que "agora é com a mamãe e o bebê"140, entre outras.

Nota-se que a segurança das mães encarceradas e de seus filhos é constantemente ameaçada. A precariedade das condições de saúde, a escassez de medicamentos e a inexistência de condições adequadas para a criação das crianças contribuem para essa ocorrência. Em reportagem para a Revista Radis, Ana Cláudia Peres ${ }^{141}$ expõe a preocupação das detentas quanto às condições habitacionais do

136 Mecanismo Estadual de Prevenção e Combate à Tortura do Rio de Janeiro. Relatório Anual do Mecanismo Estadual de Prevenção e Combate à Tortura do Rio de Janeiro. [online] Rio de Janeiro, 2018, p. 70. Disponível em: https://drive.google.com/file/d/1_G9nIwTW89hBzRnzoh9ZhIeu6JcuxzF_/view. Acesso em: 29 set. 2020.

137 G1. Detenta dá à luz em cima de saco de lixo em corredor de presídio no DF. [online] Brasília. 2015. Disponível em: http://g1.globo.com/distrito-federal/noticia/2015/05/detenta-da-luz-em-cima-de-saco-plastico-em-corredor-depresidio-no-df.html. Acesso em: 15 out. 2020.

138 BRASIL. Decreto-lei $\mathrm{n}^{\circ}$ 3.689, de 3 de outubro de 1941. Código de Processo Penal. Disponível em: http://www.planalto.gov.br/ccivil_03/Decreto- Lei/Del3689.htm. Acesso em: 29 set. 2020.

139 R7. Presa grávida dá à luz em solitária de presídio no Rio. [online] Rio de Janeiro. 2015. Disponível em: https://noticias.r7.com/rio-de-janeiro/presa-gravida-da-a-luz-em-solitaria-de-presidio-no-rio-26102015. Acesso em: 15 out. 2020.

140 Mecanismo Estadual de Prevenção e Combate à Tortura do Rio de Janeiro. Relatório Anual do Mecanismo Estadual de Prevenção e Combate à Tortura do Rio de Janeiro. [online] Rio de Janeiro, 2018, p. 70-71.

141 PERES, Ana Cláudia. Mães no Cárcere Sofrem com Graves Ameaças ao Cotidiano, à Sua Saúde e à de Seus Filhos. Revista Radis, n. 172, Rio de Janeiro, janeiro de 2017, p. 16 -19. 
sistema prisional. Desse modo, ela reporta que uma das internas revelou ter dividido a cela com seu filho, na época, de apenas três meses de vida, e outras cinco presas durante quatro meses e 15 dias.

Além da carência de ambiente confortável para habitação e de outros elementos fundamentais para uma gestação saudável, as futuras mães ainda se deparam com espaços insalubres, cujas incidências de HIV atingem proporções 138 vezes maiores do que as encontradas no exterior da instituição, enquanto a probabilidade de contaminação por tuberculose aumenta em 49 vezes ${ }^{142}$.

Além disso, Luana Hordones Chaves e Isabela Cristina Alves de Araújo ${ }^{143}$ apontam descontentamentos e reclamações quanto ao tipo de parto, explicam que as internas tendem a compreender a obrigatoriedade do parto natural como uma maneira de puni-las, já que, no Brasil, prevalece a preferência pela cesárea. Entretanto, tais preocupações revelam um outro impasse crucial na realidade dessas mulheres, que é a limitação de seu direito à escolha e de sua autonomia, o que se repete em inúmeros outros pormenores da vida dessa população.

De acordo com a Resolução nº 113 de 2010, do CNJ, a presa tem direito a receber, no mínimo uma vez ao ano, o atestado de pena a cumprir. A entrega desse documento tem como intuito informar a pessoa privada de liberdade sobre a proximidade dos prazos para pedidos de progressão de pena ou liberdade condicional ${ }^{144}$. Desta forma, a apenada pode pedir a progressão de regime, sendo que, se não houver a disponibilização de tal documento, existe a possibilidade de que o preso passe mais tempo do que o necessário no cárcere para o cumprimento da pena.

Outrossim, a precariedade do acesso à informação torna-se, nesse contexto, um fator de grande impacto à saúde mental das internas, visto que muitas são presas provisórias e estão à espera de seu julgamento. No caso daquelas que são mães, a situação de angústia se agrava, pois carregam o peso da decisão de indicação da guarda dos filhos e, consequentemente, a apreensão em relação ao momento da separação da criança, quando a idade dessa já não admitir sua permanência na instituição prisional, conforme demonstram Luana Hordones Chaves e Isabela Cristina Alves de Araújo:

Entrevistadora - E como você acha que vai ser quando seu neném sair daqui? Entrevistada 1- Eu vou embora para casa, gente, pelo amor de Deus, em nome de Jesus. Eu.... Eu fico,

${ }^{142}$ FRAGOSO, N. et al. Filhos e algemas nos braços: enfrentamento do encarceramento feminino e suas graves consequências sociais. In: Instituto Alana. (Org.). Pela Liberdade: a história do habeas corpus coletivo para mães e crianças. 1ed. São Paulo: Instituto Alana, 2019, v. 1, p. 14.

143 CHAVES, Luana Hordones; ARAÚJO, Isabela Cristina Alves de. Gestação e Maternidade em Cárcere: cuidados de saúde a partir do olhar das mulheres presas em uma unidade materno-infantil. Physis vol. 30 n. 1, Rio de Janeiro, 2020. p. 16.

144 BRASIL. Conselho Nacional de Justiça, 2020. Cartilha da Mulher Presa. 2. ed. 2012. Disponível em: https://www.cnj.jus.br/wp-content/uploads/2011/11/cartilha_da_mulher_presa_1_portugues_4.pdf. Acesso em: 15 out. 2020. 
assim, nessa esperança de ir embora. Até mesmo antes de ganhar, mas se for da vontade de Deus, não é?! Se for permissão. Se o juiz entender que eu tenho que pagar meu erro ${ }^{145}$.

A inquietação gerada pela dificuldade do acesso à informação é acentuada após a separação, quando, em muitos casos, a mãe desconhece a localização ou estado do filho.

Um outro fator a ser analisado é a dificuldade do acesso à informação quanto aos serviços e procedimentos de saúde aos quais as internas são submetidas. Ressalta-se que, no Brasil, as principais causas de morte materna, eclâmpsia e hemorragia ${ }^{146}$, estão diretamente ligadas à ineficácia da identificação de riscos e à inadequação do pré-natal. Nessa perspectiva, foi incluída a Rede Cegonha, dentre outras redes de atenção à saúde, na Portaria nº 4.279 do Ministério da Saúde, para estabelecer diretrizes de cuidados sobre saúde obstétrica e neonatal, sendo as mulheres privadas de liberdades posteriormente integradas a essa linha ${ }^{147}$. Todavia, persiste, em diversos casos, o reduzido grau de informação dessas mulheres sobre seus corpos e suas condições de saúde. Ainda, constata-se o uso de procedimentos como a manobra de Kristeller e a episiotomia, considerados prejudiciais pela OMS, em $37 \%$ e $56 \%$ dos partos ${ }^{148}$. Logo, a desinformação representa também uma ameaça à vida dessas mulheres e seus filhos.

Durante a pandemia da COVID-19, pode-se imaginar que a situação das gestantes apenadas, que já era crítica, piorou. Nesse panorama, diversas organizações formalizaram pedidos de substituição da medida de privação de liberdade por medidas alternativas, para pessoas de determinados grupos considerados de risco, como as gestantes.

Em 2018, o Supremo Tribunal Federal brasileiro julgou o Habeas Corpus $143.641^{149}$, que concedeu a ordem de substituição da prisão preventiva pela domiciliar para todas as mulheres presas, gestantes, puérperas ou mães de crianças e deficientes, o que culminou na inclusão do artigo 318-A no Código de Processo Penal ${ }^{150}$. No contexto pandêmico, essa decisão poderia preservar a saúde e a vida de muitas mulheres privadas de liberdade, no entanto, mesmo em períodos de relativa

145 CHAVES, Luana Hordones; ARAÚJO, Isabela Cristina Alves de. Gestação e Maternidade em Cárcere: cuidados de saúde a partir do olhar das mulheres presas em uma unidade materno-infantil. Physis vol. 30 no. 1 Rio de Janeiro, 2020. p. 10-11.

146 DELZIOVO, C. R.; OLIVEIRA, C. S.; JESUS, L. O. \& COELHO, E. B. (2015). Atenção à Saúde da Mulher Privada de Liberdade: manual. Florianópolis: Universidade Federal de Santa Catarina, p. 18.

147 BRASIL. Ministério da Saúde. Secretaria de Atenção à Saúde. Departamento de Ações Programáticas Estratégicas. Coordenação de Saúde no Sistema Prisional. Inclusão das mulheres privadas de liberdade na rede cegonha. Brasília: Ministério da Saúde, 2014.

148 DELZIOVO, C. R.; OLIVEIRA, C. S.; JESUS, L. O. \& COELHO, E. B. (2015). Atenção à Saúde da Mulher Privada de Liberdade: manual. Florianópolis: Universidade Federal de Santa Catarina, p. 19.

149 Supremo Tribunal Federal. Habeas Corpus $\mathbf{n}^{\mathbf{0}}$ 143.641. São Paulo, 2018. Disponível em: http://www.stf.jus.br/arquivo/cms/noticiaNoticiaStf/anexo/HC143641final3pdfVoto.pdf. Acesso em: 29 set. 2020.

150 Art. 318-A: “A prisão preventiva imposta à mulher gestante ou que for mãe ou responsável por crianças ou pessoas com deficiência será substituída por prisão domiciliar, desde que: I - não tenha cometido crime com violência ou grave ameaça a pessoa; II - não tenha cometido o crime contra seu filho ou dependente”. 
normalidade, a maioria dos pedidos de substituição da prisão preventiva pela domiciliar é negada. No Tribunal de Justiça de São Paulo, por exemplo, 85\% dos pedidos foram indeferidos ${ }^{151}$.

Em março de 2020, o CNJ, por meio da Recomendação $n^{\circ}$ 62, indicou algumas medidas que poderiam ser tomadas pelos Tribunais para prevenir a propagação da infecção pelo novo coronavírus, dentre as quais se destaca o artigo $5^{\circ}$, que orienta os magistrados, com competência sobre a execução penal, a concederem a saída antecipada dos regimes fechado e semiaberto às mulheres gestantes, lactantes, mães ou pessoas responsáveis por criança de até 12 anos, entre outros casos ${ }^{152}$.

De acordo com o Departamento Penitenciário Brasileiro, mais de 26 mil presos foram diagnosticados com COVID-19, dado que não apresenta distinções entre unidades masculinas, femininas e mistas. Com isso, não é possível afirmar quantas mulheres e gestantes privadas de liberdade estão doentes, quantas se recuperaram e quantas vieram a óbito ${ }^{153}$.

O aumento da população carcerária feminina não foi seguido de mudanças estruturais no sistema. Como exposto, são claras as violações de direitos humanos e de direitos fundamentais nesses espaços, que vulnerabilizam ainda mais as mulheres que estão sob tutela do Estado. Há grande deficiência na atualização dos dados referentes à população carcerária de um modo geral, contudo, na questão das mulheres gestantes, lactantes e em período de pós-parto, essa dificuldade acentua a invisibilidade dessas mulheres no sistema, o que resulta na inadaptação das prisões para as necessidades deste grupo. A tarefa de mensuração de dados referentes ao alcance do direito ao acesso à informação, por parte dessas mulheres, é igualmente complexa. Apesar disso, a própria escassez dos dados também indica, de certo modo, o descomprometimento estatal com tal questão.

\section{Vb. A infância no cárcere}

É inegável que, onde há mães ou pais privados de liberdade, há, por conseguinte, crianças e adolescentes afetadas pela situação. No Brasil, por exemplo, estima-se que 1.446 crianças vivam em centros de detenções com suas mães. No que se refere à faixa etária dos filhos que estão nos

${ }^{151}$ RAVAGNANI, Christopher; NEVES, Bruno; ITO, Josielly. Mães encarceradas: apesar de contrariar STF, TJSP negou 85\% dos pedidos de prisão domiciliar. Justificando. 27 de junho de 2019. Disponível em: http://www.justificando.com/2019/06/27/maes-encarceradas-apesar-de-contrariar-stf-tjsp-negou-85-dos-pedidos-deprisao-domiciliar/. Acesso em: 29 set. 2020.

152 BRASIL. Conselho Nacional de Justiça, 2020. Recomendação $\mathbf{n}^{\mathbf{0}}$ 62. Disponível em: https://atos.cnj.jus.br/files/original160026202003305e82179a4943a.pdf. Acesso em: 29 set. 2020.

153 Departamento Penitenciário Nacional. Painel de Monitoramento dos Sistemas Prisionais, 2020. [online] Disponível em:

https://app.powerbi.com/view?r=eyJrIjoiYThhMjk5YjgtZWQwYS00ODlkLTg4NDgtZTFhMTgzYmQ2MGVlIiwid CI6ImViMDkwNDIwLTQ0NGMtNDNmNy05MWYyLTRiOGRhNmJmZThlMSJ9. Acesso em: 29 set. 2020. 
estabelecimentos penais, temos que 20,54\% têm entre 0 a 6 meses; 3,25\% de 6 meses a 1 ano; 15,15\% de 1 a 2 anos; 17,77\% de 2 a 3 anos; e 43,29\% têm mais de 3 anos ${ }^{154}$.

A maioria das crianças vivendo nas unidades prisionais possui mais de 3 anos, não sendo apenas bebês recém-nascidos que ainda estão com suas mães no período de amamentação ${ }^{155}$. Este perfil de crianças maiores vivendo intramuros exige a implementação de políticas públicas específicas pelo Estado a fim de que estas crianças possam usufruir de seus direitos sem restrições advindas da situação de privação de liberdade de suas mães.

Sobre o impacto gerado nas crianças pelo encarceramento de um dos genitores, deve-se inicialmente ressaltar que o encarceramento materno o torna maior devido a diferentes razões: primeiro porque as crianças são mais propensas a viver com a mãe antes do encarceramento ${ }^{156}$, dados do Brasil demonstram que em 89\% dos casos as mães são responsáveis pela criação dos filhos na faixa etária de até 3 anos, enquanto em cerca de 5\% dos casos a responsabilidade é paterna e, em outros 5\%, os cuidadores são avós, tios ou outras pessoas ${ }^{157}$.

Segundo, pois os arranjos dos cuidados são diferentes se o pai ou a mãe vai para a prisão: no primeiro caso, a mãe das crianças geralmente cuida delas; no segundo, porém, são principalmente avós ou outros membros da família que assumem as responsabilidades de cuidados, ou elas acabam institucionalizadas ${ }^{158}$.

Além disso, o menor número de centros de detenção feminina faz com que as mães geralmente sejam alojadas longe de seu local de residência habitual, o que dificulta o contato com

${ }^{154}$ Levantamento Nacional de Informações Penitenciárias (INFOPEN). Período de julho a dezembro de 2019. Disponível em:

https://app.powerbi.com/view?r=eyJrIjoiMmU4ODAwNTAtY2IyMS00OWJiLWE3ZTgtZGNjY2ZhNTYzZDliIiwi dCI6ImViMDkwNDIwLTQ0NGMtNDNmNy05MWYyLTRiOGRhNmJmZThIMSJ9. Acesso em: 17 out. 2020.

155 Não há diretrizes na legislação brasileira que fixem qual seria a idade máxima das crianças que residem em centros penitenciários com suas mães. O prazo geralmente adotado na prática é de um período mínimo de 6 meses, que corresponderia ao tempo recomendado para a amamentação exclusiva. Especialistas na questão, contudo, sugerem que a separação deva ocorrer a partir dos 3 anos de idade, devendo ser acompanhada por equipe multidisciplinar, composta de psicólogos, médicos e assistentes sociais, a fim de resguardar a incolumidade psíquica da criança e de sua mãe, bem como a preservação dos laços de afetividade existentes. (Relatório Final do Grupo de Trabalho Interministerial para reorganização e reformulação do sistema prisional feminino. Secretaria Especial de Políticas para as Mulheres do Ministério da Justiça, dez/2007. Disponível em: http://ittc.org.br/wpcontent/uploads/2013/09/git_mulheres.pdf. p. 88). Acesso em: 17 out. 2020.

156 GIACOMELLO, Corina. Niñas y Niños que Viven en Prisión con sus Madres: una perspectiva jurídica comparada. Primera edición. Ciudad de México, México: Suprema Corte de Justicia de la Nación, 2018. p. 12.

${ }^{157}$ FUNDAÇÃO Maria Cecília Souto Vidigal. Primeiríssima Infância - Creche: necessidades e interesses de famílias e crianças. Fundação Maria Cecília Souto Vidigal; São Paulo, 2017. P. 17. Disponível em: https://crianca.mppr.mp.br/arquivos/File/publi/fmcsv/primeirissima_infancia_creche_ibope_fmcsv_2017.pdf. Acesso em: 17 out. 2020.

158 GIACOMELLO, Corina. Niñas y Niños que Viven en Prisión con sus Madres: una perspectiva jurídica comparada. Primera edición. Ciudad de México, México: Suprema Corte de Justicia de la Nación, 2018. p. 13. 
parentes, inviabiliza a convivência familiar, e faz crescer na criança o impacto gerado pelo encarceramento ${ }^{159}$.

Dessa maneira, é evidente que o impacto gerado na vida das crianças, cujo referencial adulto (que geralmente é a mãe) é privado de liberdade, não depende apenas de fatores endógenos, ligados às características da família e comunidade em que a criança está inserida, mas também de fatores exógenos, que se relacionam, sobretudo, ao funcionamento do sistema penal, duração das penas e condições de encarceramento ${ }^{160}$.

Nessa toada, os Estados, detentores do poder punitivo, são também responsáveis por parte considerável dos impactos causados na vida dessas crianças e devem, portanto, adotar medidas para reduzir esses graves efeitos gerados nas crianças em decorrência do encarceramento de seus pais.

No caso específico de crianças vivendo junto às suas mães no cárcere, o desafio é ainda maior, devendo haver um esforço do Estado no sentido de garantir os direitos destas crianças, bem como de não permitir que a pena perpasse o condenado e venha a atingir o infante (princípio da intranscendência da pena). Ressalta-se que elas têm os mesmos direitos que as outras crianças e não devem ser tratadas como se estivessem em conflito com a lei em decorrência das ações de seus pais ${ }^{161}$.

Para delimitar a área de atuação dos Estados na proteção desse grupo vulnerável e invisibilizado $^{162}$, faz-se necessária uma prévia análise do corpus iuris a respeito das garantias e dos direitos humanos das crianças. No sistema interamericano, as crianças - consideradas as pessoas com menos de 18 anos - são titulares dos direitos estabelecidos na CADH, além de ter as medidas especiais de proteção contempladas em seu artigo 19, que garante a toda criança o direito às medidas de proteção que a sua condição de vulnerabilidade requer por parte da sua família, da sociedade e do Estado.

O Protocolo de San Salvador consagra de maneira específica, em seu artigo 16, além da proteção especial que fazem jus as crianças devido à sua condição de vulnerabilidade, também direitos à educação, pelo menos em nível básico, e à convivência familiar.

159 GIACOMELLO, Corina. Niñas y Niños que Viven en Prisión con sus Madres: una perspectiva jurídica comparada. Primera edición. Ciudad de México, México: Suprema Corte de Justicia de la Nación, 2018. p. 13.

160 GIACOMELLO, Corina. Niñas y Niños que Viven en Prisión con sus Madres: una perspectiva jurídica comparada. Primera edición. Ciudad de México, México: Suprema Corte de Justicia de la Nación, 2018. p. 13.

${ }^{161}$ CIDH. Hacia la Garantía Efectiva de los Derechos de Niñas, Niños y Adolescentes: Sistemas Nacionales de Protección. Aprobado por la Comisión Interamericana de Derechos Humanos el 30 de noviembre de 2017. par. 6. Disponível em: http://www.oas.org/es/cidh/informes/pdfs/NNA-GarantiaDerechos.pdf. Acesso em: 18 out. 2020.

162 CIDH. Hacia la Garantía Efectiva de los Derechos de Niñas, Niños y Adolescentes: Sistemas Nacionales de Protección. Aprobado por la Comisión Interamericana de Derechos Humanos el 30 de noviembre de 2017. par. 6. Disponível em: http://www.oas.org/es/cidh/informes/pdfs/NNA-GarantiaDerechos.pdf. Acesso em: 18 out. 2020. 
Conforme apontado na OC $n^{0}$ 17/02 de 28 de agosto de $2002^{163}$, a Corte na oportunidade da sentença de mérito do Caso “Niños de la Calle” (Villagrán Morales y otros Vs. Guatemala), destacou a existência de um "corpus iuris muito abrangente de direito internacional para a proteção dos direitos da criança”, que deve ser utilizado como fonte de direito para a Corte estabelecer “o conteúdo e alcance” das obrigações assumidas pelo Estado por meio do artigo 19 da CADH, em particular ao especificar as “medidas de proteção” a que se refere no dispositivo ${ }^{164}$.

Nesse sentido, é necessário pontuar a importância da Convenção sobre os Direitos da Criança, aprovada pela ONU em novembro de 1989, como parâmetro de garantias, uma vez que é o marco do desenvolvimento internacional para a proteção dos direitos humanos das crianças. Junto com outros instrumentos, a mencionada Convenção faz parte de um vasto corpo jurídico sobre o tema que, além de se referir aos direitos humanos intrínsecos das pessoas - como o direito à vida, à liberdade, à autodeterminação e à igualdade, entre outros -, elucida o direito à proteção específica que possuem as crianças ${ }^{165}$.

Dentre os princípios abordados pela Convenção sobre os Direitos da Criança, merece particular destaque aquele referente ao melhor interesse da criança, destacado em seu artigo $3^{\text {o166 }}$, que implica a obrigação dos Estados de adotarem decisões e priorizarem as intervenções que favoreçam a efetivação dos direitos da criança e do adolescente, bem como sua proteção ${ }^{167}$.

No âmbito interamericano, o melhor interesse da criança também é um ponto de partida. No julgamento do caso Caso González e outros (“Campo Algodonero”) vs. México, por exemplo, a Corte IDH determinou que a prevalência do melhor interesse da criança deve ser entendida como a necessidade de cumprir todos os direitos da infância e da adolescência, o que obriga o Estado e irradia efeitos na interpretação de todos os demais direitos da Convenção quando o caso se refere a esse grupo $^{168}$.

163 CORTE IDH. Opinião Consultiva 17/2002, 2002, par. 24.

${ }^{164}$ CORTE IDH. Caso de los “Niños de la calle” (Villagrán Morales y otros). Sentencia de 19 de noviembre de 1999. Serie C, No. 63, par. 194.

165 GIACOMELLO, Corina. Niñas y Niños que Viven en Prisión con sus Madres: una perspectiva jurídica comparada. Primera edición. Ciudad de México, México: Suprema Corte de Justicia de la Nación, 2018. p. 12.

166 Artigo 3.1: Todas as ações relativas à criança, sejam elas levadas a efeito por instituições públicas ou privadas de assistência social, tribunais, autoridades administrativas ou órgãos legislativos, devem considerar primordialmente o melhor interesse da criança.

${ }^{167}$ CIDH. Hacia la Garantía Efectiva de los Derechos de Niñas, Niños y Adolescentes: Sistemas Nacionales de Protección. Aprobado por la Comisión Interamericana de Derechos Humanos el 30 de noviembre de 2017. par. 6. Disponível em: http://www.oas.org/es/cidh/informes/pdfs/NNA-GarantiaDerechos.pdf. Acesso em: 18 out. 2020. par. 1.

${ }^{168}$ CORTE IDH. Caso González y Otras (“Campo Algodonero”) Vs. México. Excepción Preliminar, Fondo, Reparaciones y Costas. Sentencia del 16 de noviembre de 2009. Série C No. 205 p. 7-8. 
Além do melhor interesse da criança, outro princípio extraível da Convenção dos Direitos da Criança e que deve irradiar todas as normas de proteção infantil é o princípio da não discriminação. Sobre esse princípio, a CIDH recentemente destacou que:

En base al principio de igualdad y de no discriminación los Estados deben identificar activamente aquellos grupos de NNA que se encuentren en una situación de vulnerabilidad de sus derechos y que requieren de intervenciones focalizadas a sus necesidades de protección con el objetivo de dar efectividad a sus derechos. El principio de no discriminación no impide que se adopten medidas especiales para disminuir situaciones de desigualdad o discriminación y de hecho dicho principio puede requerir la adopción de medidas proactivas para responder a tales situaciones. Para ello es imprescindible que la norma prevea los mecanismos para identificar cuáles son estos grupos y situaciones. Una de las medidas adecuadas para ello es que los datos que se reúnan se desglosen adecuadamente para poder identificar los grupos en particulares situaciones de vulnerabilidad, que no tienen sus derechos garantizados, así como las situaciones de discriminación. Otra medida que contribuye a esta identificación es la consulta directa con los NNA, con las organizaciones de la sociedad civil, y con expertos y la academia. Especialmente difícil es la tarea de identificar estos grupos vulnerables cuando éstos no son grupos tradicionalmente identificados como en situación de vulnerabilidad, y que por tanto se encuentran invisibilizados, como por ejemplo los NNA hijos de padres/madres privados de libertad ${ }^{169}$.

Usando-se do melhor interesse da criança e do princípio da não discriminação como lentes para enxergar os direitos deste público específico, existem três grupos de direitos humanos que merecem ser vistos e serão analisados no contexto da crianças que vivem com mães privadas de liberdade: (i) direito à vida familiar da criança; (ii) direito à saúde e à alimentação e (iii) desenvolvimento adequado das crianças que vivem em centros de detenção com as mães, inclusive o relacionado à integração comunitária, à socialização, à educação e à recreação.

A vinculação da família como elemento fundamental da sociedade (conforme artigo 17 da $\mathrm{CADH})$ e os direitos das crianças a medidas de proteção específicas por sua condição de pessoa em desenvolvimento (conforme artigo 19 da $\mathrm{CADH}$ ) tornam claro o posicionamento desta Corte no sentido de que a convivência familiar constitui um direito das crianças e protege o melhor interesse delas. Em diversas oportunidades, a Corte se manifestou afirmando que a separação de crianças de seu seio familiar é medida que deve ser tomada apenas em últimos casos e deve-se sempre priorizar a manutenção do núcleo familiar ${ }^{170}$.

O posicionamento adotado na OC $n^{\circ}$ 17/02 e reiterado no julgamento do Caso Forneron e Hija vs. Argentina retrata o direito que a criança tem de viver com sua família, a qual tem o dever de

169 CIDH. Hacia la Garantía Efectiva de los Derechos de Niñas, Niños y Adolescentes: Sistemas Nacionales de Protección. Aprobado por la Comisión Interamericana de Derechos Humanos el 30 de noviembre de 2017. par. 6. Disponível em: http://www.oas.org/es/cidh/informes/pdfs/NNA-GarantiaDerechos.pdf. Acesso em: 18 out. 2020. par. 81.

170 Como por exemplo em: CORTE IDH. Opinião Consultiva 17/2002, 2002, par. 72, 75 y 77; Caso Forneron e Hija Vs. Argentina. Fondo, Reparaciones y Costas. Sentencia de 27 de abril de 2012. Serie C No. 242, par. 47. 
satisfazer suas necessidades materiais, afetivas e psicológicas. O desfrute mútuo da convivência entre pais e filhos constitui um elemento fundamental na vida da família e, por isso, a criança deve permanecer no seu núcleo familiar, salvo se existirem razões determinantes, em função do interesse superior da criança, para optar pela separação. Em todo caso, a separação deve ser excepcional e, preferencialmente, temporal ${ }^{171}$.

Por outro lado, é cediço que o sistema carcerário não é o ambiente adequado para o desenvolvimento integral e sadio das crianças, razão pela qual devem ser priorizadas a prisão domiciliar e demais medidas alternativas de sua genitora ${ }^{172}$, com base nos princípios da proteção integral e do melhor interesse da criança ${ }^{173}$.

Na mesma direção, os documentos do Sistema Africano de Direitos Humanos e dos Povos (Carta Africana dos Direitos e Bem-Estar da Criança) ${ }^{174}$ e do Sistema Global de Proteção (Regras de Bangkok) ${ }^{175}$ determinam de maneira explícita que os Estados devem dar preferência a uma pena diferente da pena de prisão para as mães que cumprem penas.

Ampliando esse entendimento, no primeiro General Comment emitido pelo African Committee of Experts on the Rights and Welfare of the Child, em 2013, o Comitê elucidou o conteúdo do art. 30 da Carta dos Direitos da Criança, afirmando que os Estados devem considerar penas alternativas sempre que o réu for o principal responsável por uma ou mais crianças - e não apenas

${ }^{171}$ CORTE IDH. Opinião Consultiva 17/2002, 2002, par. 67 y 71; Caso Forneron e Hija Vs. Argentina. Fondo, Reparaciones y Costas. Sentencia de 27 de abril de 2012. Serie C No. 242, par. 46.

172 Neste sentido, no Relatório sobre medidas destinadas a reduzir o uso da prisão preventiva nas Américas, a CIDH já se manifestou no sentido de que "em relação à determinação das medidas alternativas à prisão preventiva para mulheres, os Estados devem promover a inclusão da perspectiva de gênero em todas suas dimensões e, se for o caso, do enfoque do interesse superior da criança e de proteção especial para outras pessoas em situação especial de risco, tais como pessoas com deficiência e pessoas idosas”, sendo que, para impor medidas alternativas as autoridades devem considerar, entre outros elementos o "impacto diferenciado e agravado da aplicação da pena privativa da liberdade nas pessoas sob o seu cuidado” (par. 203). Disponível em: http://www.oas.org/pt/cidh/relatorios/pdfs/PrisaoPreventiva.pdf. Acesso em: 16 out. de 2020.

173 Resolução n 210 de 5/06/2018, do Conselho Nacional dos Direitos da Criança e do Adolescente, que dispõe sobre os direitos de crianças cujas mães, adultas ou adolescentes, estejam em situação de privação de liberdade. “Art. $2^{\circ}$. Deve ser priorizada a manutenção da criança com a mãe, fora do cárcere, em liberdade ou em prisão domiciliar, com base nos princípios norteadores dos direitos da criança, bem como na legislação pertinente”. Disponível em: https://crianca.mppr.mp.br/arquivos/File/legis/conanda/resolucao_conanda_210_2018_maes_privadas_de_liberdade. pdf. Acesso em: 16 out. de 2020.

174 Organização para a Unidade Africana, Carta Africana dos Direitos e Bem-Estar da Criança. Addis Abeba, Etiópia, 1990. Artigo 30 - Crianças de mães prisioneiras: Os Estados Partes a presente Carta adotarão medidas adequadas por forma a providenciar tratamento especial às mães grávidas e às mães com bebés e crianças menores que tenham sido acusadas ou declaradas culpadas de terem infringido a lei penal e devem em particular: (a) garantir que a aplicação de uma sentença não custodial, seja sempre considerada como principal alternativa no pronunciamento da sentença de tais mães.

175 Regra 58: Considerando as provisões da regra 2.3 das Regras de Tóquio, mulheres infratoras não deverão ser separadas de suas famílias e comunidades sem que se considere devidamente a sua história e laços familiares. Formas alternativas de lidar com mulheres infratoras, tais como medidas despenalizadoras e alternativas à prisão, inclusive à prisão cautelar, deverão ser empregadas sempre que apropriado e possível. 
quando for a mãe ${ }^{176}$. Ainda neste documento, o Comitê Africano determinou que os critérios presentes em uma decisão para se avaliar se uma criança deve viver em cárcere com sua mãe precisam levar em consideração as características individuais da criança - tais como idade, sexo, grau de maturidade e qualidade da relação com o seu cuidador ou cuidadora principal - e a existência de alternativas de cuidados de qualidade acessível ${ }^{177}$.

A despeito do entendimento normativo internacional, ao analisar a realidade de alguns países, como por exemplo o Brasil, percebe-se que não raras vezes há a permanência de crianças em estabelecimentos prisionais. Conforme já exposto, estima-se que cerca de 1.446 crianças vivem em situação de cárcere juntamente de suas mães no Brasil atualmente ${ }^{178}$.

Em face da perseverante inércia institucional no país, por meio do supracitado Habeas Corpus Coletivo $\mathrm{n}^{\circ} 143.641^{179}$, o Supremo Tribunal Federal brasileiro foi provocado a se manifestar acerca das violações realizadas e da necessidade de preservação dos direitos das mulheres e crianças no cárcere ${ }^{180}$. O julgamento referido indica significativos avanços e foi, inclusive, seguido de inovação legislativa com conteúdo similar (art. 318-A e 318-B, Código de Processo Penal).

No entanto, a praxe dos tribunais e juízos ainda é criar entraves para referida prisão domiciliar, com exigência, como regra, de comprovação da “imprescindibilidade da mãe” para os cuidados com a criança, o que, por certo, subverte a lógica da decisão, invertendo de forma indevida o ônus da prova, culminando em violação ao direito da criança de ser criada em ambiente extramuros.

176 African Committee of Experts on the Rights and Welfare of the Child (ACERWC); General Comment n. 1 (article 30 of the African Charter on the Rights and Welfare of the Child) on "Children of Incarcerated and Imprisoned Parents and Primary Caregivers”. Disponível https://www.acerwc.africa/wpcontent/uploads/2018/04/General_Comment_Article_30_ACRWC_English.pdf. Acesso em: 17 out. 2020.

177 African Committee of Experts on the Rights and Welfare of the Child (ACERWC); General Comment n. 1 (article 30 of the African Charter on the Rights and Welfare of the Child) on "Children of Incarcerated and Imprisoned Parents and Primary Caregivers”. Disponível em: https://www.acerwc.africa/wpcontent/uploads/2018/04/General_Comment_Article_30_ACRWC_English.pdf. Acesso em: 17 out. 2020.

${ }^{178}$ Levantamento Nacional de Informações Penitenciárias (INFOPEN). Período de julho a dezembro de 2019. Disponível

em: https://app.powerbi.com/view?r=eyJrIjoiMmU4ODAwNTAtY2IyMS00OWJiLWE3ZTgtZGNjY2ZhNTYzZDliIiwi dCI6ImViMDkwNDIwLTQ0NGMtNDNmNy05MWYyLTRiOGRhNmJmZThlMSJ9. Acesso em: 17 out. 2020.

${ }^{179}$ No bojo do decisório foi concedida ordem para determinar a substituição da prisão preventiva pela domiciliar - sem prejuízo da aplicação concomitante das medidas alternativas previstas no art. 319 do Código de Processo Penal - de todas as mulheres presas, gestantes, puérperas ou mães de crianças e deficientes, nos termos do art. $2^{\circ}$ do Estatuto da Criança e do Adolescente e da Convenção sobre Direitos das Pessoas com Deficiências (Decreto Legislativo 186/2008 e Lei 13.146/2015), enquanto perdurar tal condição, excetuados os casos de crimes praticados por elas mediante violência ou grave ameaça contra seus descendentes ou, ainda, em situações excepcionalíssimas. (STF. $2^{\mathrm{a}}$ Turma. HC coletivo $n^{\circ}$ 143641/SP. Rel. Min. Ricardo Lewandowski, julgado em 20/2/2018. Disponível em: http://www.stf.jus.br/arquivo/cms/noticiaNoticiaStf/anexo/HC143641final3pdfVoto.pdf. Acesso em: 17 out. de 2020.).

180 Acerca dessa mesma problemática em outros momentos se manifestou o Supremo Tribunal Federal: HC 147.322MC/SP, HC 142.279/CE, HC 130.152-MC/SP, de relatoria do Ministro Gilmar Mendes, HC 134.979/DF, HC 134.130/DF, HC 133.179/DF e HC 129.001/SP, de relatoria do Ministro Roberto Barroso, HC 133.532/DF, de relatoria do Ministro Marco Aurélio, HC 134.734-MC/SP, de relatoria do Ministro Celso de Mello. 
Após o vencimento do prazo de 60 dias estabelecido para que fossem implementadas as medidas de proteção a mães e crianças determinadas por meio do Habeas Corpus $n^{0}$ 143.641, o Departamento Penitenciário (DEPEN) enviou ofício ao Supremo Tribunal Federal informando que apenas 426 das 10.500 mulheres mães tiveram a prisão domiciliar aplicada.

O benefício legal não é concedido em face de pré-julgamentos subjetivos de cunho moral, racial, social e cultural ${ }^{181}$. Nesse sentido, o relatório descreve que “o judiciário julga a mulher não apenas por ter infringido a lei, mas por estar infringindo um ideal de maternidade" ${ }^{182}$. As mulheres que tiveram seus filhos na prisão são vistas como irresponsáveis; aquelas que não querem ver os seus filhos enquanto estão dentro do ambiente prisional são consideradas cruéis e as que tiveram os filhos fora da prisão, ao irem para o sistema prisional, são acusadas de abandonarem e não se importarem com os filhos ${ }^{183}$.

Sobre esse ponto, destaca-se que as decisões não podem se utilizar do melhor interesse da criança como um motivo para discriminar mães e pais com base em argumentos fundados em estereótipos e preconceitos. As decisões devem estar baseadas em avaliações de comportamentos parentais específicos e seus impactos negativos no bem-estar e desenvolvimento da criança conforme o caso, os danos ou riscos reais e comprovados, e não especulativos ou imaginários. Portanto, especulações, presunções, estereótipos ou considerações generalizadas sobre características pessoais dos pais ou preferências culturais em relação a certos conceitos tradicionais de família não podem ser admissíveis $^{184}$.

Ademais, não se pode olvidar que o momento de separação entre a mãe encarcerada e a criança (nos casos em que esta já nasceu no interior do estabelecimento prisional) é, em geral, uma situação delicada e dramática. Portanto, caso a decisão venha a concluir pela separação da criança de seus pais, cabe ao Estado promover a devida informação sobre a decisão para a pessoa presa e, além

${ }^{181}$ O Instituto Terra, Trabalho e Cidadania (ITTC), a partir do relatório “Diagnóstico da Aplicação do Marco Legal da Primeira Infância para o Desencarceramento de Mulheres”, descreve que "existe uma forte resistência do judiciário em aplicar a prisão domiciliar”. Nas audiências de custódia, 83\% das mulheres que eram potenciais beneficiárias tiveram seus direitos negados. Segundo o estudo, das 107 mulheres que pleitearam o benefício da prisão domiciliar instituída Lei n 13.769/2019 a fim de propiciar aproximação da mãe e seu(a) filho(a), 90 dos pedidos foram negados. Quando se trata dos Tribunais Superiores, a taxa de concessão do benefício aumenta para 61,37\%, porém, o processo de acesso às instâncias superiores brasileiras é custoso.

182 Instituto Terra, Trabalho e Cidadania. Diagnóstico da Aplicação do Marco Legal da Primeira Infância para o Desencarceramento de Mulheres.

183 LOPES, Rosalice. Prisioneiras de uma mesma história: o amor materno atrás das grades. 245 fls. Tese (doutorado em psicologia) Universidade de São Paulo, São Paulo, 2004. p. 149.

184 CORTE IDH. Caso Atala Riffo y Niñas Vs. Chile. Fondo, Reparaciones y Costas. Sentencia de 24 de febrero de 2012. Serie C No. 239, par. 109. 
disso, fornecer suporte para que o vínculo familiar seja mantido ${ }^{185}$. Sobre o assunto, a Regra de Bangkok n 52 estipula o seguinte:

\begin{abstract}
Regra 52
1. A decisão do momento de separação da mãe de seu filho deverá ser feita caso a caso e fundada no melhor interesse da criança, no âmbito da legislação nacional pertinente.

2. A remoção da criança da prisão deverá ser conduzida com delicadeza, e apenas quando alternativas de cuidado da criança tenham sido identificadas e, no caso de presas estrangeiras, com consulta aos funcionários/as consulares.

3. Uma vez separadas as crianças de suas mães e colocadas com familiares ou parentes, ou sob outras formas de cuidado, serão oferecidas às mulheres presas o máximo de oportunidades e condições para encontrar-se com seus filhos e filhas, quando estiver sendo atendido o melhor interesse das crianças e a segurança pública não for comprometida.
\end{abstract}

Como se verifica da legislação brasileira, no momento de separação do infante e da mãe presa é importante a atuação conjunta com o Ministério Público, Defensoria Pública, Poder Judiciário e demais entidades de proteção dos direitos da criança, para que sejam localizados membros da família extensa aptos a cuidar dessa criança, ou, na ausência destes, que haja o encaminhamento à uma instituição de acolhimento, sempre havendo a atualização e informação sobre esta localidade, a fim de que não se rompam os laços familiares ${ }^{186}$. Ressalta-se também a necessidade de intimação pessoal da mãe ou do pai encarcerado nos casos de ações de destituição do poder familiar, sendo esta obrigação prevista expressamente no art. 158, §2 ${ }^{\circ}$, do Estatuto da Criança e do Adolescente (ECA) ${ }^{187}$.

Além disso, conforme já destacado anteriormente e observado na normativa acima exposta, a convivência entre pais e filhos constitui um elemento fundamental na vida de uma família. Nesse sentido, a Corte Europeia de Direitos Humanos estabeleceu que mesmo quando os pais são separados de seus filhos, a convivência familiar deve ser mantida, de modo que quaisquer medidas que impeçam esse exercício configuram ingerências ao artigo 8 da Convenção Sobre os Direitos das Crianças ${ }^{188}$.

Destacam-se, nesse ponto, as disposições estabelecidas nas Regras de Bangkok, sobretudo as Regras 4, 22, 23, 26 e 28, que fornecem diretrizes para a convivência familiar entre familiares privados de liberdade e crianças. Assim, a Regra 4 indica que as mulheres presas deverão permanecer,

\footnotetext{
185 Artigos 17 e 19 da CADH; artigo 10 do PIDESC; artigos 23 e 24 do PIDCP, artigo 16, par. 3, da Declaração Universal dos Direitos Humanos.

186 Estatuto da Criança e do Adolescente (arts. 19 e ss); Resolução Conselho Nacional de Política Criminal e Penitenciária - CNPCP n ${ }^{\circ}$ de 15/07/2009 - Dispõe sobre a estada, permanência e posterior encaminhamento das(os) filhas(os) das mulheres encarceradas.

Disponível

em: https://www.legisweb.com.br/legislacao/?id=112041\#: :text=A\%20Uni\%C3\%A3o\%20e\%20os\%20Estados,at\%C3 \%A9\%20dois\%20anos\%20de\%20idade. Acesso em: 17 out. 2020.

187 Art. 158, § $2^{\circ}$, do Estatuto da Criança e do Adolescente: O requerido privado de liberdade deverá ser citado pessoalmente. (Incluído pela Lei ${ }^{\circ} 12.962$, de 2014).

188 COUNCIL OF EUROPE. European Court of Human Rights. Case of Ahmut Vs. the Netherlands, Judgment of 27 November 1996, Reports 1996-VI, par. 60; Case of Gül Vs. Switzerland, Judgment of 19 February 1996, Reports 1996-I, par. 32; Case of Berrehab Vs. the Netherlands, Judgment of 21 June 1988, Series A no. 138, par. 21.
} 
na medida do possível, em prisões próximas ao seu meio familiar ou local de reabilitação social, considerando justamente suas responsabilidades como fonte de cuidado; as Regras 22 e 23 dispõem, respectivamente, sobre a proibição de isolamento ou segregação disciplinar a mulheres com filhos/as e sobre a impossibilidade de sanções que proíbam contato com a família, especialmente com crianças; a Regra 26 busca facilitar o contato das mulheres presas com seus familiares, incluindo seus filhos/as, com quem detém a guarda de seus filhos/as e seus representantes legais; a Regra 28, por fim, determina que as visitas que envolvam crianças devem ser realizadas em um ambiente propício a uma experiência positiva, e destaca o contato direto entre mães e filhos/as em visitas prolongadas. ${ }^{189}$

No ordenamento jurídico brasileiro, o ECA, que é a legislação referência para a proteção dos direitos da criança em âmbito doméstico, prevê que devem ser oportunizadas visitas periódicas ao estabelecimento penal onde o genitor privado de liberdade se encontra e que essas visitas devem ocorrer no interior de instalações que não remontem a hostilidade do ambiente carcerário - de preferência locais sem grades e que contem com higiene e salubridade condizentes com a dignidade humana. 190

Ademais, em acordo com as normativas internacionais ${ }^{191}$, consta na legislação interna que não deve ser um requisito para o ingresso em centros penitenciários das crianças a submissão a tratamentos vexatórios, como é o caso da revista íntima, devendo, se for o caso, optar por mecanismos menos invasivos, por exemplo, detectores de metais e afins. ${ }^{192}$

Nessa análise, cabe pontuar, por fim, que infelizmente a convivência familiar não é a realidade vivida pela maioria da população carcerária, sobretudo feminina. Dados de presídios localizados no estado do Paraná, no Brasil, mostram que mulheres e gestantes possuem um índice de abandono familiar que beira $80 \%$ após o cometimento de um delito e apenas cerca de $10 \%$ de seus companheiros, namorados ou maridos ainda as visitam após o cárcere. Tendo em vista que a maioria das mulheres possui filhos, infere-se que o abandono se estende às crianças, quando elas vivem

189 ASSEMBLEIA GERAL DAS NAÇÕES UNIDAS. Escritório das Nações Unidas Sobre Drogas e Crime (UNODC). Regras das Nações Unidas para o Tratamento de Mulheres Presas e Medidas Não Privativas de Liberdade para Mulheres Infratoras (Regras de Bangkok). A/RES/65/229. Suíça: Assembleia Geral da ONU, 2010.

190 Art. 19, § $4^{\circ}$, do Estatuto da Criança e do Adolescente; Política Nacional de Atenção às Mulheres em Situação de Privação de Liberdade e Egressas do Sistema Prisional - PNAMPE, instituída pela Portaria Interministerial MJ/SPM $n^{\circ} 210 / 2014$.

191 Regra 20 das Regras de Bangkok (2010) - Deverão ser desenvolvidos outros métodos de inspeção, tais como escâneres, para substituir revistas íntimas e revistas corporais invasivas, de modo a evitar os danos psicológicos e possíveis impactos físicos dessas inspeções corporais invasivas.

192 Neste sentido, há a Política Nacional para a Atenção a Mulheres em Situação de Privação de Liberdade e Egressas do Sistema Prisional - PNAMPE, que em seu art. $3^{\circ}$, II, i, prevê: o respeito à dignidade no ato de revista às pessoas que ingressam na unidade prisional, inclusive crianças e adolescentes. Disponível em: http://www.lex.com.br/legis_25232895_PORTARIA_INTERMINISTERIAL_N_210_DE_16_DE_JANEIRO_DE_ 2014.aspx. Acesso em: 17 out. 2020. 
encarceradas com as mães. ${ }^{193}$

No tocante ao direito à saúde, em reiteradas decisões, como no caso Chinchilla Sandoval Vs. Guatemala $^{194}$, a Corte expressou que o direito à vida (art. 4 da CADH) e a integridade pessoal (art. 5 da $\mathrm{CADH}$ ) estão diretamente vinculados com a atenção à saúde humana. Tais direitos, combinados com o preceito da não discriminação, implicam ao Estado a obrigação de garantir a saúde física e mental através de revisão médica regular e de tratamento especializado adequado e atento às necessidades especiais do detento, quando requerido ${ }^{2}$. Ainda neste caso, a Corte se manifestou sobre a necessidade específica de reforço da manutenção do nível de qualidade nos serviços de saúde equivalente ao de quem não se encontra privado de liberdade ${ }^{195}$.

Referido vínculo entre integridade pessoal e a atenção a saúde é desenvolvido no Caso Rodríguez Revolorio e outros Vs. Guatemala ${ }^{196}$, no qual se expandem fatores mensuráveis - tais como o estado de saúde, o tempo transcorrido sem atenção médica, o efeito físico e mental acumulativos de possíveis doenças e até mesmo o sexo e a idade - como possíveis indicadores de violações dos artigos 5.1 e 5.2 da CADH. Ademais, é dada ênfase à importância de atenção à saúde mental e à alimentação, em especial quando esta poderia afetar condições pré-existentes de vulnerabilidade - neste caso específico sendo diabéticos, hipertensos e detentos que possuíam úlceras. Neste sentido, no caso Mendoza e outros Vs. Argentina ${ }^{197}$ esta Corte reforça o artigo 24.1 da Convenção sobre os Direitos da Criança ${ }^{198}$, o qual requer que os Estados signatários reconheçam o direito da criança de gozar do melhor padrão de saúde possível e de serviços de tratamento de doenças e recuperação da saúde.

Quando se trata de crianças que vivem no cárcere, em acompanhamento da detenção de seus responsáveis, surgem novas fragilidades. Não havendo cometido nenhum delito, acompanham parte da pena de seus responsáveis fraternos de forma a manter vínculo afetivo importante para seu

193 Dados informados pelo Conselho da Comunidade da Comunidade da Comarca da Região Metropolitana de Curitiba - Órgão da Execução Penal. Disponível em: https://www.plural.jor.br/noticias/vizinhanca/apenas-20-das-mulherespresas-recebem-visitas/. Acesso em: 17 out. 2020.

194 CORTE IDH. Chinchilla Sandoval Vs. Guatemala. Sentencia de 29 de febrero de 2016. Serie C No. 312, par. 170 y 171.

195 CORTEIDH. Chinchilla Sandoval Vs. Guatemala. Sentencia de 29 de febrero de 2016. Serie C No. 312 , par. 177.

196 CORTE IDH. Rodríguez Revolorio e outros Vs. Guatemala. Sentencia de 14 de octubre de 2019. Serie C No. 387, par. 90.

197 CORTE IDH. Mendoza e outros Vs. Argentina. Sentencia de 14 de mayo de 2013. Serie C No. 260, par. 191.

198 Artigo 24.1 da Convenção sobre os Direitos da Criança - Os Estados Partes reconhecem o direito da criança de gozar do melhor padrão possível de saúde e dos serviços destinados ao tratamento das doenças e à recuperação da saúde. Os Estados Partes devem envidar esforços para assegurar que nenhuma criança seja privada de seu direito de usufruir desses serviços de cuidados de saúde. 
desenvolvimento ${ }^{199}$. Vivem um dilema que em muitos casos poderia ser evitado, uma vez que estes responsáveis muitas vezes poderiam estar servindo formas de pena menos onerosas para as crianças $^{200}$. Entretanto, quando este não for o caso, todo Estado signatário das Regras de Bangkok se compromete ao treinamento básico de funcionários voltado à saúde da criança ${ }^{201}$ (Regra 33.3); ao acesso a serviços permanentes de saúde e supervisão de especialistas ${ }^{202}$ (Regra 51.1); além do compromisso com uma alimentação gratuita e pontual, tanto para a criança quanto para mulheres grávidas ou lactantes ${ }^{203}$ (Regra 48).

Tendo em vista a pandemia do vírus COVID-19 em 2020, a Unicef emitiu nota técnica referente a medidas a serem adotadas para preservar os direitos de crianças e adolescentes em privação de liberdade ${ }^{204}$. Algumas destas medidas envolvem testar todas as crianças e adolescentes, além de seus cuidadores; a detenção em estabelecimentos de saúde em casos de isolamento ou quarentena por motivos de saúde; o monitoramento quanto aos sintomas da doença; proporcionar melhorias no acesso à água, saneamento, serviços e suprimentos de higiene; manter o devido processo legal e garantias processuais; manutenção e ampliação do contato destes vulneráveis com seus responsáveis e família e a prevenção da admissão de novas crianças em instalações de internação durante este período.

Utilizando dados do Estado do Brasil como forma de observarmos as repercussões destas normas e recomendações no âmbito da América Latina, chega-se à constatação de que a realidade da grande parte das unidades prisionais brasileiras é a ausência de espaços específicos adequados para alojar essas crianças e suas mães, sendo os berçários muitas vezes compostos de celas improvisadas,

199 Regra 49 das Regras de Bangkok (2010) - Decisões para autorizar os filhos a permanecerem com suas mães na prisão deverão ser fundamentadas no melhor interesse da criança. Crianças na prisão com suas mães jamais serão tratadas como presas.

${ }^{200}$ CIDH. Relatório Medidas Destinadas a Reduzir o Uso da Prisão Preventiva nas Américas, OEA/Ser.L/V/II.163 Doc. 105, 3 de julho de 2017, par. 202.

${ }^{201}$ Regra 33.3 das Regras de Bangkok (2010) - Quando crianças puderem acompanhar suas mães na prisão, os funcionários também serão sensibilizados sobre as necessidades de desenvolvimento das crianças e será oferecido treinamento básico sobre atenção à saúde da criança para que respondam com prontidão a emergências.

202 Regra 51.1 das Regras de Bangkok (2010) - Crianças vivendo com as mães na prisão deverão ter acesso a serviços permanentes de saúde e seu desenvolvimento será supervisionado por especialistas, em colaboração com serviços de saúde comunitários.

203 Regra 48 das Regras de Bangkok (2010) - 1. Mulheres grávidas ou lactantes deverão receber orientação sobre dieta e saúde dentro de um programa a ser traçado e supervisionado por um profissional da saúde qualificado. Deverá ser fornecida gratuitamente alimentação adequada e pontual para gestantes, bebês, crianças e lactantes em um ambiente saudável e com a possibilidade para exercícios físicos regulares. 2. Mulheres presas não deverão ser desestimuladas a amamentar seus filhos, salvo se houver razões de saúde específicas para tal. 3. As necessidades médicas e nutricionais das mulheres presas que tenham recentemente dado à luz, mas cujos filhos não se encontram com elas na prisão, deverão ser incluídas em programas de tratamento.

${ }^{204}$ UNICEF. Nota Técnica: COVID-19 e Crianças e Adolescentes em Privação de Liberdade. Disponível em: https://www.unicef.org/brazil/media/8466/file/covid-19-e-criancas-e-adolescentes-em-privacao-de-liberdade.pdf/. Acesso em: 17 out. 2020. 
que remontam a condição de insalubridade, falta de higiene e indignidade ${ }^{205}$. Diversas destas unidades são mistas ou se tornaram unidades exclusivamente femininas supervenientemente, o que contribui para que a própria arquitetura das unidades não levasse em consideração a perspectiva de gênero e as necessidades das crianças que estão junto às suas mães encarceradas. O que há (e quando há) são adaptações a espaços que sempre foram masculinos.

Quanto ao cumprimento da normativa 33.3 das Regras de Bangkok, encontramos dados alarmantes, com relação ao staff dos berçários e/ou creches, nas unidades prisionais que contam com estas instalações específicas, apenas uma quantidade ínfima tem a presença de equipe própria para atendimento (sete contam com pediatras; cinco com ginecologistas; e seis com nutricionistas; não havendo dados sobre a presença de cuidadores) $)^{206}$.

Em relação à normativas nacionais, o ECA preocupou-se em trazer disposições específicas sobre crianças com genitores privados de liberdade, como é o caso do art. $8^{\circ}$, $§ 10$, que trata do dever do Estado em garantir às crianças vivendo ou convivendo com mães custodiadas a ambiência adequada que atenda às normas sanitárias e assistenciais do Sistema Único de Saúde e que estejam articuladas com o sistema de ensino competente, em vistas ao desenvolvimento integral da criança.

Ainda, neste aspecto, cabe a análise dos seguintes documentos domésticos brasileiros: (i) a Resolução ${ }^{\circ} 210$ de 5/06/2018, do Conselho Nacional dos Direitos da Criança e do Adolescente, que dispõe sobre os direitos de crianças cujas mães, adultas ou adolescentes, estejam em situação de privação de liberdade ${ }^{207}$; e (ii) a Política Nacional de Atenção às Mulheres em Situação de Privação de Liberdade e Egressas do Sistema Prisional (PNAMPE), instituída pela Portaria Interministerial Ministério da Justiça e Secretaria de Políticas para Mulheres (MJ/SPM) nº 210/2014, que possui como

205 Relatório sobre Mulheres Encarceradas no Brasil, fevereiro de 2007, produzido em parceria por: CEJIL, AJD, ITCC, CNBB, IDDD, ASBRAD, CTB, IBCCRIM, Centro Dandara de Promotoras Legais Popular. Disponível em: https://carceraria.org.br/wp-content/uploads/2013/02/Relato\%CC\%81rio-para-OEA-sobre-Mulheres-Encarceradasno-Brasil-2007.pdf. Acesso em: 17 out. 2020. p. 38.

${ }^{206}$ Levantamento Nacional de Informações Penitenciárias (INFOPEN). Período de julho a dezembro de 2019. Disponível em: https://app.powerbi.com/view?r=eyJrIjoiMmU4ODAwNTAtY2IyMS00OWJiLWE3ZTgtZGNjY2ZhNTYzZDliIiwi dCI6ImViMDkwNDIwLTQ0NGMtNDNmNy05MWYyLTRiOGRhNmJmZThlMSJ9. Acesso em: 17 out. 2020.

207 Esta Resolução, em seu artigo $3^{\circ}$, enumera os direitos que devem receber especial atenção nos casos de crianças que permanecem intramuros com as suas mães, dentre os quais: a) direito à saúde, com a garantia de consultas médicas para acompanhar o integral desenvolvimento da criança; b) direitos à saúde e à alimentação, com observância ao direito ao aleitamento materno exclusivo até pelo menos os 6 meses de vida; e c) direito à dignidade, ao respeito e à liberdade, garantindo-se condições dignas e salubres para permanência de crianças com suas mães e evitando qualquer exposição da criança a tratamento desumano, violento, aterrorizante, vexatório ou constrangedor. Disponível em: https://crianca.mppr.mp.br/arquivos/File/legis/conanda/resolucao_conanda_210_2018_maes_privadas_de_liberdade. pdf. Acesso em: 17 out. 2020. 
uma de suas diretrizes a proteção da infância e da maternidade, preocupando-se com o mapeamento e a assistência à criança em ambiente intra e extramuros ${ }^{208}$.

Relativamente ao desenvolvimento adequado das crianças que vivem em centros de detenção com as mãe, tendo em vista o supracitado art. 19 da CADH, o qual reconhece a responsabilidade da família, sociedade e Estado no que tange à salvaguarda dos direitos das crianças, é evidente que referido direito ao desenvolvimento adequado, à integração comunitária, à socialização, à educação e à recreação das crianças devem ser protegidos e configuram como uma responsabilidade do Estado, sobretudo, observando os arts. 1 e 2 da CADH, os quais definem a obrigação de respeitar os direitos contidos neste ordenamento sem discriminação e o dever de adotar disposições de direito interno. No entanto, quando estas crianças vivem em prisões com suas mães privadas de liberdade, como já dito, tal necessidade de tutela aumenta, devido às diversas situações de vulnerabilidade as quais ficam expostas.

A Convenção sobre os Direitos das Crianças prevê em seu artigo 6.2 que o Estado deve garantir a sobrevivência e o desenvolvimento da criança, enquanto seu artigo 27 traz como direito de toda criança um nível de vida adequado, para que tenha um desenvolvimento físico, mental, moral e social. Visto isso, é imprescindível que seja ofertado o melhor ambiente possível dentro das prisões para que a criança possa desenvolver o máximo de suas capacidades de forma plena e harmoniosa ${ }^{209}$, respeitando, ainda, a fase de desenvolvimento infantil, as quais necessitam de um ambiente acolhedor, sem violência, com estímulos, alimentação e acesso à saúde de forma adequada ${ }^{210}$.

Neste mesmo tratado, os artigos 28 e 29 consolidam o direito à educação para todas as crianças de forma igualitária de modo que promova o desenvolvimento da personalidade e da sua capacidade física e mental. Ressalta-se que a educação primária deve ser gratuita e disponível para todos, algo previsto também no art.13 do Protocolo de São Salvador, submetido ao art. 26 da $\mathrm{CADH}^{211}$ sobre desenvolvimento progressivo, assim, tais direitos devem ser implementados imediatamente, ao passo que o Estado não pode alegar constrição orçamentária para não cumprir esta

\footnotetext{
${ }^{208}$ A Política Nacional de Atenção às Mulheres em Situação de Privação de Liberdade e Egressas do Sistema Prisional PNAMPE, em suas metas, dispostas em seu art. $4^{\circ}$, trata especificamente da assistência material (alimentação, vestuário e instalações higiênicas, incluindo itens básicos) e do acesso à saúde dos filhos inseridos em contexto prisional. Disponível em: http://www.lex.com.br/legis_25232895_PORTARIA_INTERMINISTERIAL_N_210_DE_16_DE_JANEIRO_DE_ 2014.aspx Acesso em: 17 out. 2020.

${ }^{209}$ CORTE IDH. Caso de los “Niños de la Calle” (Villagrán Morales y otros) Vs. Guatemala. Sentencia de 19 de noviembre de 1999. Serie C No. 63, par. 191.

${ }^{210}$ UNICEF. Desenvolvimento Infantil. Disponível em: https://www.unicef.org/brazil/desenvolvimento-infantil. Acesso em: 15 out. 2020.

${ }^{211}$ CORTE IDH. Caso Guzmán Albarracín y otras Vs. Ecuador. Fondo, Reparaciones y Costas. Sentencia de 24 de junio de 2020. Serie C No. 405, par. 117.
} 
obrigação. Soma-se a isso o direito à educação de qualidade, que demanda um ambiente educacional o mais aproximado possível daquele fora da prisão, de acordo com a regra 51.2 das Regras de Bangkok. Nessa toada, a Opinião Consultiva OC $n^{0}$ 17/02 se posiciona da seguinte forma:

[...] [D]entro de las medidas especiales de protección de los niños y entre los derechos reconocidos a éstos en el artículo 19 de la Convención Americana, figura de manera destacada el derecho a la educación, que favorece la posibilidad de gozar de una vida digna y contribuye a prevenir situaciones desfavorables para el menor y la propia sociedad. ${ }^{212}$

As atividades educacionais, lúdicas, culturais e recreativas têm como um de seus benefícios a interação com outras crianças ${ }^{213}$, algo que deve ser observado e proporcionado tanto entre as crianças que vivem intramuros, quanto entre estas e as que vivem em suas residências, visto que a socialização e a integração comunitária fomentam o desenvolvimento infantil e os princípios de igualdade perante a lei e de não discriminação, presente no art. 24 da CADH. Além disso, é necessário que o Estado adote medidas positivas e especiais ${ }^{214}$, incluindo a elaboração de programas sólidos e contínuos em cooperação com outras instâncias estatais e com a sociedade civil ${ }^{215}$. Sobre as atividades supramencionadas, a Convenção sobre os Direitos das Crianças traz em seu artigo 31 o seguinte conteúdo:

1. Los Estados Partes reconocen el derecho del niño al descanso y el esparcimiento, al juego y a las actividades recreativas propias de su edad y a participar libremente en la vida cultural y en las artes. 2. Los Estados Partes respetarán y promoverán el derecho del niño a participar plenamente en la vida cultural y artística y propiciarán oportunidades apropiadas, en condiciones de igualdad, de participar en la vida cultural, artística, recreativa y de esparcimiento.

É importante destacar que tais direitos se estendem a crianças com algum tipo de deficiência, as quais devem desfrutar de uma vida plena, digna e participativa na comunidade, segundo o Comitê de Direitos das Crianças, o qual assevera similarmente que não deve haver exclusão e tampouco descriminação para com elas ${ }^{216}$. Sendo assim, todo o suporte possível para uma educação inclusiva deve ser fornecido também no cárcere.

212 CORTE IDH. Condición Jurídica y Derechos Humanos del Niño. Opinión Consultiva OC-17/02 de 28 de agosto de 2002. Serie A No. 17, párr. 84.

${ }^{213} \mathrm{CIDH}$, Informe Derecho del Niño y la Niña a la Familia, Cuidado Alternativo, Poniendo fin a la Institucionalización en las Américas. OEA/Ser.L/V/II. Doc.54/13, 17 de octubre de 2013, par. 633.

${ }^{214}$ CIDH. Hacia la Garantía Efectiva de los Derechos de Niñas, Niños y Adolescentes: Sistemas Nacionales de Protección. Aprobado por la Comisión Interamericana de Derechos Humanos el 30 de noviembre de 2017. para. 6. Disponível em: http://www.oas.org/es/cidh/informes/pdfs/NNA-GarantiaDerechos.pdf. Acesso em: 18 out. 2020. par. 291.

215 GIACOMELLO. Corina. Niñas y niños que viven en prisión con sus madres: una perspectiva jurídica comparada. México: Suprema Corte de Justicia de la Nación, 2018.

216 COMITÊ PARA O DIREITO DAS CRIANÇAS. Comentario General No. 9, Los derechos de los niños con discapacidad, CRC/C/GC/9, 27 de febrero de 2007, 43o período de sesiones, par. 49. 
No caso do Estado brasileiro, em consonância à normativa internacional, promoveu em 2009 a alteração do artigo 89 da Lei de Execução Penal (LEP), para dispor que “a penitenciária de mulheres será dotada de seção para gestante e parturiente e de creche para abrigar crianças maiores de 6 (seis) meses e menores de 7 (sete) anos, com a finalidade de assistir a criança desamparada cuja responsável estiver presa”, definindo como requisitos básicos para estes locais, além das condições de salubridade e higiene, "o atendimento por pessoal qualificado, de acordo com as diretrizes adotadas pela legislação educacional e em unidades autônomas", bem como um "horário de funcionamento que garanta a melhor assistência à criança e à sua responsável”.

No mesmo sentido, a supracitada Política Nacional de Atenção às Mulheres em Situação de Privação de Liberdade e Egressas do Sistema Prisional (PNAMPE), instituída pela Portaria Interministerial MJ/SPM n ${ }^{\circ}$ 210/2014, que possui como uma de suas diretrizes a proteção da infância e da maternidade, em seu artigo $3^{\circ}$, enumera os direitos que devem receber especial atenção nos casos de crianças que permanecem intramuros com as suas mães, sendo que especificamente elencada a necessidade de propiciar:

[...] à criança a permanência e o contato com sua mãe em espaços e ambientes saudáveis, separados da unidade prisional e de internação, os quais devem proporcionar rotinas próprias e específicas, bem como oferecer atividades lúdicas, psicossociais, e de atenção à saúde física e mental, buscando o desenvolvimento da criança e o fortalecimento do vínculo maternoinfantil, objetivando reduzir o impacto negativo do ambiente carcerário e de internação para a criança e sua mãe.

No entanto, a realidade fática brasileira encontra-se divorciada das normativas previstas tanto em nível internacional, como interno. De acordo com os dados mais recentes, conforme Levantamento Nacional de Informações Penitenciárias (INFOPEN), realizado entre junho e dezembro de $2019^{217}$, das unidades prisionais avaliadas, apenas 55 contavam com berçários, havendo uma capacidade de atendimento de 598 bebês, o que por certo não supre a demanda nos estabelecimentos em questão, visto que, à época, estimava-se que o total de crianças no cárcere correspondia a 1.446 e 276 gestantes. ${ }^{218}$

${ }^{217}$ Levantamento Nacional de Informações Penitenciárias (INFOPEN). Período de julho a dezembro de 2019. Disponível https://app.powerbi.com/view?r=eyJrIjoiMmU4ODAwNTAtY2IyMS00OWJiLWE3ZTgtZGNjY2ZhNTYzZDliIiwi dCI6ImViMDkwNDIwLTQ0NGMtNDNmNy05MWYyLTRiOGRhNmJmZThIMSJ9. Acesso em: 17 out. 2020.

${ }^{218}$ Levantamento Nacional de Informações Penitenciárias (INFOPEN), Período de julho a dezembro de 2019. Disponível 
No tocante às creches, estas estão presentes em somente 13 das unidades femininas ou mistas, com capacidade para 154 crianças $^{219}$, sendo este número ainda mais limitado que a oferta de berçários. Aqui, também convém destacar que nas unidades masculinas avaliadas, não há a presença de creches, o que demarca também o estereótipo de gênero em relação à mulher enquanto cuidadora nata das crianças.

Estes números absolutos, em dados percentuais, indicam que: (i) nos estabelecimentos femininos, apenas 32\% dispõem de berçário ou centro de referência materno infantil e apenas 5\% dispõem de creche; e (ii) nos estabelecimentos mistos, apenas 6\% das unidades dispõem de espaço específico para a custódia de gestantes, apenas 3\% dispõem de berçário ou centro de referência materno infantil e nenhum dispõe de creche ${ }^{220}$.

Por fim, no INFOPEN, não constam dados acerca da existência de escolas para crianças no interior das unidades prisionais e nem se o Poder Público disponibiliza transporte e/ou de outra forma viabiliza a inserção destas crianças na rede regular de ensino, o que potencialmente configura violação ao direito à educação.

\section{Alerta de hipervulneração: COVID-19}

A pandemia da COVID-19 não apenas aguçou as vulnerabilidades e ampliou exclusões no cenário brasileiro, mas também lançou luzes para o abismo existente entre os hipervulneráveis e a (ausência) das políticas públicas.

São vulneráveis aqueles que têm diminuídas, por diferentes razões, suas capacidades de enfrentar as eventuais violações à direitos básicos. Sabemos que o maior grau de vulnerabilidade das pessoas depende de diferentes fatores físicos, econômicos, sociais e políticos; e, durante a grave crise provocada pela COVID-19, notamos que as medidas e mecanismos criados como respostas para minimizar ou reduzir as violações de direitos não chegam às pessoas que integram certos grupos em situação de hipervulnerabilidade, em especial àquelas privadas de liberdade.

A CIDH emitiu, em 10 de abril, a Resolução 01/2020, intitulada "Pandemia e Direitos Humanos nas Américas”, na qual apresenta um conjunto de medidas e abordagens para o

${ }^{219}$ Levantamento Nacional de Informações Penitenciárias (INFOPEN), Período de julho a dezembro de 2019. Disponível https://app.powerbi.com/view?r=eyJrIjoiMmU4ODAwNTAtY2IyMS00OWJiLWE3ZTgtZGNjY2ZhNTYzZDliIiwi dCI6ImViMDkwNDIwLTQ0NGMtNDNmNy05MWYyLTRiOGRhNmJmZThIMSJ9. Acesso em: 17 out. 2020.

${ }^{220}$ STF. $2^{\text {a }}$ Turma. HC coletivo n 143641/SP. Rel. Min. Ricardo Lewandowski, julgado em 20/2/2018. Disponível em: http://www.stf.jus.br/arquivo/cms/noticiaNoticiaStf/anexo/HC143641final3pdfVoto.pdf. Acesso em: 17 out. 2020. p. 10. 
enfrentamento da COVID-19 sob a ótica dos Direitos Humanos pelos países latino-americanos. Esse documento é um produto da Sala de Coordenação e Resposta Oportuna e Integrada à pandemia do COVID-19 (SACROI COVID-19), instituída no âmbito da Organização dos Estados Americanos (OEA), que tem por objetivo oferecer aportes para os países do bloco lidarem com a crise sanitária sob a perspectiva dos direitos humanos.

Dentre as 85 recomendações, as de número 39 e 40 tratam de grupos de especial vulnerabilidade, indicando que os Estados membros devem:

\begin{abstract}
39. Considerar abordagens diferenciadas ao tomar medidas necessárias para garantir os direitos dos grupos em uma situação de especial vulnerabilidade, adotando medidas de cuidado, tratamento e contenção para a pandemia de COVID-19; bem como mitigar os impactos diferenciados que tais medidas podem gerar.

40. Promover, pelas mais altas autoridades, a eliminação de estigmas e estereótipos negativos que podem surgir em certos grupos de pessoas no contexto de pandemia ${ }^{221}$.
\end{abstract}

É, portanto, também desta noção das peculiaridades aguçadas pela COVID-19 que o presente amicus curiae partilha, demonstrando que os cenários acima detalhados agudizam-se ainda mais. Consoante acima posto, diversas são as consequências pandêmicas como fatores de ainda maior exposição às violações sistemáticas e institucionalizadas vividas no cárcere.

\title{
VII. Respostas objetivas aos quesitos
}

A. No que se refere à proteção dos direitos de pessoas em especial situação de vulnerabilidade, como mulheres grávidas, em pós-parto e lactantes; pessoas LGBT; pessoas indígenas; pessoas idosas; e crianças que vivem em centros de detenção com as mães, é possível justificar nos artigos 24 e 1.1 da Convenção a necessidade da adoção de medidas ou enfoques diferenciados para garantir que suas circunstâncias específicas não afetem a igualdade de condições com as demais pessoas privadas da liberdade, tanto no que diz respeito a suas condições de detenção como em relação aos recursos que sejam interpostos para proteger seus direitos no contexto da privação da liberdade? Em caso positivo, que implicações concretas reveste o conteúdo dos direitos envolvidos nesses artigos no alcance das obrigações correlatas que cabem aos Estados na matéria?

A interpretação dos artigos 1.1 e 24 da CADH exige a consideração de vulnerabilidades, inclusive (i) quando múltiplas e interseccionais e (ii) com critérios de identificação que não foram

${ }^{221}$ CIDH. Resolução 1/2020. Pandemia e Direitos humanos nas Américas. Aprovada em 10/04/2020. Disponível em: https://www.oas.org/pt/cidh/decisiones/pdf/Resolucao-1-20-pt.pdf. Acesso em: 17 out. 2020. 
elencados pela CIDH, como ótica de leitura do significado de igualdade. É que os artigos da CADH não se vinculam a um paradigma formalista, mas sim ao de uma igualdade substancial, que reconhece a necessidade de proteção especial para determinados grupos. Assim, esse tratamento diferenciado não contraria o mandado de igualdade, mas o cumpre.

Considerando pessoas encarceradas, a falta de adoção de medidas especiais importaria em consequências do cárcere muito mais deletérias para esses grupos vulneráveis. Num plano concreto, a igualdade impõe que o Estado garanta condições materiais e adote disposições de direito interno para que essas consequências sejam afastadas.

B. Sobre as mulheres privadas da liberdade grávidas, em pós-parto e lactantes. À luz dos artigos 1.1, 4.1, 5, 11.2, 13, 17.1 e 24 da Convenção Americana sobre Direitos Humanos, do artigo 7 da Convenção Interamericana para Prevenir, Punir e Erradicar a Violência contra a Mulher e de outros instrumentos interamericanos aplicáveis, que obrigações específicas cabem aos Estados para garantir que as mulheres grávidas, em pós-parto e lactantes privadas da liberdade gozem de condições de detenção que sejam adequadas, atendendo a suas circunstâncias peculiares? Em especial:

1. Que obrigações específicas cabem aos Estados em matéria de alimentação, vestuário e acesso a assistência médica e psicológica?

Quanto à alimentação, os Estados devem: (i) suprir regularmente o fornecimento de água para cuidados especiais, (ii) prover orientação em relação à dieta a partir de um programa elaborado e revisto por um profissional de saúde qualificado, (iii) fornecer alimentação gratuita, pontual e adequada, considerando, especialmente, uma dieta com alto teor de proteína, rica em frutas e vegetais, ofertando inclusive suplemento dietético quando for preciso. No que tange à vestimenta, os Estados precisam fornecer uniformes em condições adequadas às presas, não apresentando furos ou rasgos e roupas de cama adequadas.

No que diz respeito ao acesso à assistência médica e psicológica, espera-se que os Estados: (i) disponibilizem profissionais médicos qualificados com conhecimento em psiquiatria, incluindo-se também a disponibilidade de tratamento psiquiátrico caso seja este o diagnóstico, além de produtos farmacêuticos específicos necessários para os tratamentos adequados, incluindo necessidades odontológicas, (ii) forneçam instalações adequadas para o tratamento de mulheres gestantes, lactantes ou em pós-parto, (iii) providenciem atendimento apropriado, médico e psicológico, para mulheres 
grávidas em decorrência de abuso sexual, inclusive disponibilizando acesso a abortivos nos casos em que for legal, (iv) garantam um ambiente que proporcione exercícios físicos regulares e com exposição diária à luz natural, ventilação e calefação apropriadas, segundo as condições climáticas do local de privação de liberdade, (v) abstenham-se de aplicar, em relação às mulheres grávidas e das mães que convivam com os filhos no interior dos estabelecimentos de privação de liberdade, medidas de isolamento em celas de castigo, (vi) assegurem o acesso a tratamentos de saúde preventivos, (vii) garantam o acesso a medicação consumida antes da situação de privação de liberdade, (viii) promovam o acesso a métodos contraceptivos e acesso ao aborto nos casos em que for legal e (ix) avaliem a possibilidade de concessão de medidas alternativas à prisão, uma vez que esse ambiente pode ser um fator de risco à saúde de mulheres grávidas, lactantes ou em pós-parto, especialmente no contexto pandêmico.

\section{Que condições mínimas o Estado deve garantir durante o trabalho de parto e durante o parto?}

No que tange às condições mínimas garantidas para a mulher durante o trabalho de parto e durante o parto, os Estados devem: (i) abster-se absolutamente da utilização de instrumentos de contenção como correntes e algemas, (ii) garantir a preferência de dar à luz fora do ambiente prisional, o que não obsta o dever de fornecer um ambiente seguro dentro da prisão caso o bebê venha nascer lá, (iii), assegurar que o transporte até o ambiente hospitalar seja feito em prazo razoável e (iv) garantir a presença de acompanhante de escolha da própria mulher.

\section{Que medidas de segurança o Estado pode adotar ao efetuar a transferência de mulheres grávidas, a fim de que sejam compatíveis com suas necessidades especiais?}

Em relação às medidas de segurança adotadas durante à transferência de mulheres grávidas, entende-se que são deveres dos Estados: (i) abster-se absolutamente da utilização de instrumentos de contenção nas mulheres em trabalho de parto, durante o parto ou no período imediatamente posterior e (ii) garantir a realização em prazo razoável do transporte até o ambiente hospitalar. 
4. Qual o alcance do direito ao acesso à informação, no contexto de privação de liberdade, das mulheres grávidas, em pós-parto e lactantes, a respeito da informação relativa a sua condição especial?

Acerca do alcance do direito à informação de mulheres grávidas, lactantes ou em pós-parto sobre sua condição, é preciso que os Estados: (i) forneçam orientação adequada sobre sua condição e seus direitos em casos de mulheres grávidas em decorrência de abuso sexual, inclusive disponibilizando acesso a abortivos nos casos em que for legal, (ii) promovam uma orientação de dieta a partir de um programa elaborado e revisto por um profissional de saúde qualificado, (iii) informem a mulheres grávidas sobre a possibilidade preferencial de dar à luz fora do ambiente prisional, (iv) noticiem a mulher sobre os procedimentos médicos aos quais ela e a criança - antes e depois do nascimento - sejam submetidos, (v) notifiquem, periodicamente, o quanto de sua pena ainda resta a ser cumprido e (vi) prestem informações à mãe encarcerada sobre a situações dos seus filhos, especialmente sobre sua localização e estado de saúde.

C. Sobre as pessoas LGBT. À luz dos artigos 1.1, 4.1, 5, 11.2, 13, 17.1 e 24 da Convenção Interamericana de Direitos Humanos, do artigo 7 da Convenção Interamericana para Prevenir, Punir e Erradicar a Violência contra a Mulher, e outros instrumentos interamericanos aplicáveis: que obrigações específicas têm os Estados para garantir que as pessoas LGBT contem com condições de detenção que sejam adequadas atendendo a suas circunstâncias particulares? Em particular:

1. Como devem os Estados levar em consideração a identidade de gênero com a qual se identifica a pessoa no momento de determinar a unidade em que ela deve ingressar?

Os Estados devem garantir o direito a autodeclaração da identidade de gênero da pessoa que será privada de liberdade no momento do direcionamento à unidade prisional correspondente. Devem, ainda, entender e valorizar as vozes e as identidades dos sujeitos que destoam do padrão masculino e heterossexual dominante 


\section{Que obrigações específicas têm os Estados para prevenir todo ato de violência contra pessoas} LGBT privadas de liberdade que não impliquem segregação do resto da população carcerária?

No que se refere, especificamente, à prevenção dos atos de violência contra a população trans privada de liberdade, de forma que não implique em segregação do restante da população carcerária, os Estados devem: (i) mapear e acompanhar a população trans privada de liberdade, de forma que esse mapeamento não sirva como base para o Estado separar e agrupar travestis e transexuais de acordo com categorias, mas sim para que garanta a proteção integral e igualitária, com base nos artigos 1.1 e 24 da CADH; (ii) entender e valorizar as vozes e as identidades dos sujeitos que destoam do padrão masculino e heterossexual dominante; (iii) capacitar todos os agentes penitenciários, criar de espaços de convivência (grupos de leitura, espaços de estudo, hortas comunitárias, etc.) e fortalecer processos de autogestão da população trans privada de liberdade, em respeito especialmente aos artigos 11.2, 13 e 24 da CADH; (iv) permitir possibilidades de escolha e criar padrões mínimos de garantias que visem à igualdade de tratamento à toda população trans privada de liberdade em todo território nacional.

3. Quais são as obrigações especiais que têm os Estados a respeito das necessidades médicas especiais de pessoas trans privadas de liberdade e, em particular, se for o caso, a respeito de quem deseja iniciar ou continuar com seu processo de transição?

No tocante à saúde das pessoas trans em situação de cárcere, e levando em consideração sua situação de acentuada vulnerabilidade, devem os Estados: (i) capacitar os profissionais da saúde que atuam em presídios quanto às demandas específicas da população trans neste ponto, tais como os altos índices de HIV e ISTs, modificações corporais diversas e saúde mental; (ii) criar centros especializados para o acompanhamento da população trans em situação de cárcere; (iii) oferecer acompanhamento psicoterápico, de modo a propiciar um sentimento de autoaceitação e autovalorização; (iv) fornecer os meios adequados de proteção, profilaxia e tratamento com relação ao HIV e ISTs diversas; (v) quanto ao processo de transição, tendo em vista a Resolução n 1.955/2010 do Conselho Federal de Medicina e a Portaria n ${ }^{0}$ 1.707/2008 do Ministério da Saúde, impõe-se que o Estado possibilite o início do processo de transição ou, então, mantenha aquelas já em andamento, a fim de evitar prejuízos à saúde física e mental do indivíduo. 


\section{Que medidas especiais devem adotar os Estados para assegurar o direito à realização de visitas íntimas de pessoas LGBT?}

Sobre as medidas que buscam assegurar o direito à visita íntima para a população LGBTQI+ no sistema penitenciário, sugerimos aos Estados: (i) criação de alas específicas para a população LGBTQI+, em número suficiente para que este grupo seja protegido do preconceito dos outros detentos e garantindo maior privacidade ao grupo para que exerça seu direito à visita íntima; (ii) ampliação do acesso à saúde e melhoria de condições estruturais. $\mathrm{O}$ acesso à saúde é muito importante para a população trans, tanto para o acesso ao tratamento hormonal, como para assegurar seu direito básico de acesso à saúde e integridade física enquanto estiver sob a tutela estatal; (iii) capacitação dos servidores que atuam no sistema judiciário e penitenciário (em todos os níveis) para que os dispositivos sobre a identidade de gênero sejam reconhecidos e efetivamente aplicados, alinhados a ressocialização inclusiva, mitigando o preconceito.

\section{Que obrigações particulares têm os Estados em matéria de registro dos diferentes tipos de violência contra pessoas LGBT privadas de liberdade?}

No que diz respeito às obrigações particulares que os Estados têm em matéria de registro dos diferentes tipos de violência contra pessoas LGBTQI+ privadas de liberdade, tem-se que: (i) nos termos da Convenção Interamericana para Prevenir e Punir a Tortura, de 1985, os Estados devem tomar medidas efetivas, como capacitar policiais e demais funcionários públicos responsáveis pela custódia das pessoas privadas de liberdade; garantir que as autoridades procedam de ofício e imediatamente as realizações de investigações dos casos e, sendo o caso, iniciem o devido processo penal, assim como garantir que as vítimas destes tipos de violências sejam submetidas a exames conduzidos de maneira imparcial; (ii) alguns Estados específicos da América Latina têm adotado obrigações particulares sobre o tratamento e proteção da população LGBTQI+ privadas de liberdade, podendo-se destacar, entre eles, a Argentina, a Colômbia, El Salvador, a Guatemala, o México e o Brasil, sendo que, recentemente, no ano de 2020, houve, no Brasil, a edição da Resolução n ${ }^{0} 348$, do CNJ, que visa orientar a atuação dos magistrados, no sentido de prezar pela auto identificação das pessoas LGBTQI+ privadas de liberdade, consulta a estas pessoas sobre o estabelecimento prisional, no sentido de verificar se se adequasse às suas necessidades para o cumprimento da pena, o respeito à orientação sexual, à identidade e a expressão de gênero. 
D. Sobre crianças que vivem em centros de detenção com as mães à luz dos artigos 1.1, 4.1, 5, 17.1, 19 e 24 da Convenção Americana sobre Direitos Humanos, de outros instrumentos interamericanos aplicáveis e do interesse superior da infância, Que obrigações específicas cabem aos Estados para garantir os direitos das crianças que vivem com as mães na prisão, atendendo a suas circunstâncias peculiares?

Primeiramente, a medida primordial a ser implementada diz respeito à escassez e consequente necessidade de produção de dados específicos acerca das crianças com genitores encarcerados e/ou que vivem intramuros. Há diversos pontos cegos no que tange às especificidades da situação real e atual desta vulnerabilidade, sendo salutar o mapeamento das crianças e suas necessidades. Ou seja, a atuação em face de tais problemas se inicia com um estudo quantitativo e qualitativo das dificuldades enfrentadas e as demandas requeridas.

Logo, a coleta de dados se mostra imprescindível para a identificação e consequente concretização de direitos, sendo esta a primeira medida a ser tomada a fim de se estabelecerem diretrizes acerca do tema que se propõe.

Em que pese tal lacuna, os apontamentos a seguir pretendem abranger qualquer possível vulnerabilidade que possa afligir ou vir a afligir as crianças no cárcere.

\section{Que obrigações específicas os Estados devem assumir para assegurar o direito à vida familiar da criança, inclusive o respeito ao contato com o outro pai?}

Compete aos Estados tomar as devidas diligências para que a separação familiar não ocorra e seja preservada a manutenção do núcleo familiar, promovendo medidas para: (i) dar aos réus responsáveis por crianças, sobretudo às mães, preferência a penas alternativas ao cárcere, como a prisão domiciliar; e, no caso da existência de lei nesse sentido que esta seja devidamente aplicada; (ii) permitir que as mulheres presas permaneçam, na medida do possível, em prisões próximas ao seu meio familiar ou local de reabilitação social; (iii) proibir o isolamento ou segregação disciplinar a mulheres com filhos/as, bem como sanções que proíbam contato com a família, especialmente com crianças; (iv) considerar as características individuais da criança - tais como idade, sexo, grau de maturidade e qualidade da relação com o seu cuidador ou cuidadora principal -, além do direito da criança de ser escutada nas decisões que avaliam se ela deve viver em cárcere com sua mãe ou outro 
responsável; (v) garantir às crianças que vivem com suas mães privadas de liberdade a possibilidade de passar com elas o maior tempo possível.

Nos casos em que, com base no melhor interesse da criança, a separação entre a criança e o adulto responsável seja a medida mais apropriada, o Estado deve: (i) proferir decisões baseadas em avaliações de comportamentos parentais específicos e seus impactos negativos no bemestar e desenvolvimento da criança, garantindo que não haja separações fundadas em estereótipos e preconceitos em relação aos responsáveis; (ii) promover a atuação conjunta das entidades de proteção dos direitos da criança, para que sejam localizados membros da família extensa aptos a cuidar dessa criança, ou, na ausência destes, que haja o encaminhamento à uma instituição de acolhimento; (iii) assegurar a remoção da criança da prisão com delicadeza, e apenas quando alternativas de cuidado da criança tenham sido identificadas e, no caso das estrangeiras, com consulta aos funcionários/as consulares; (iv) fornecer assistência psicossocial à criança e ao adulto responsável privado de liberdade após a separação; (v) manter o membro da família que está preso informado sobre a localização e cuidados das crianças, promovendo, inclusive, a intimação pessoal da mãe ou do pai encarcerado e possível assistência técnica nos casos de ações de destituição do poder familiar; (vi) implementar medidas que facilitem o contato das mulheres presas com seus filhos/as com quem detém a guarda de seus filhos/as e com seus representantes legais.

Nos casos em que a pessoa responsável está privada de liberdade e possui filhos/as fora das prisões, os Estados devem: (i) ofertar aos presos e presas o máximo de oportunidades e condições para encontrar-se com seus filhos e filhas, com estabelecimentos de visitas periódicas ao estabelecimento penal onde o genitor privado de liberdade se encontra, quando estiver sendo atendido o melhor interesse das crianças; (ii) criar ambientes de visitas nos presídios femininos e masculinos que não remontem a hostilidade do ambiente carcerário, propiciando uma experiência positiva e o contato direto entre os genitores e seus filhos e filhas; (iii) garantir que nenhuma criança seja submetida a tratamentos vexatórios, como é o caso da revista íntima, no momento do ingresso em centros penitenciários, devendo, se for o caso, optar por mecanismos menos invasivos, como, por exemplo, detectores de metais e afins; (iv) viabilizar a logística, fornecendo transporte e demais suporte necessário para que as crianças que estejam em acolhimento institucional ou aquelas que não possuem recursos financeiros possam realizar visitas às mães e pais privados de liberdade.

Nos casos em que a criança está em ambiente de privação de liberdade junto de cuidador(a) responsável e possui família vivendo fora da prisão, cabe aos Estados: (i) oportunizar visitas dos familiares para as crianças dentro dos centros de detenção, observando sempre o melhor interesse da criança. Quando necessário, deve ser possibilitado acompanhamento 
profissional especializado (psicólogo/assistente social) na supervisão das visitas; (ii) permitir e viabilizar às crianças a saída dos centros de detenção para realizar visitas ao outro pai ou família extensa, quando estabelecido em acordo multilateral realizado entre genitores e homologado pelo juízo competente ou quando houver determinação judicial nesse sentido.

\section{Que obrigações tem o Estado em matéria de acesso ao direito à saúde e à alimentação de crianças que vivem em centros de detenção com as mães?}

No tocante ao direito à alimentação das crianças que vivem intramuros com as suas mães ou cuidador(a), o Estado deve: (i) garantir a oferta de água potável e de uma dieta balanceada e nutritiva, elaborada por profissionais habilitados, que seja condizente com a faixa etária e demais condições nutricionais específicas de cada criança; (ii) proporcionar uma rotina alimentar às crianças, com o estabelecimento de horários próprios para as refeições; (iii) fornecer ambientes higiênicos e salubres para a preparação, manuseio e consumo dos alimentos destinados às crianças; (iv) contratar profissionais com especialidade em segurança alimentar e nutrição (ex: nutricionistas; médicos; etc.) para elaborar e supervisionar o plano alimentar das crianças; (v) realizar avaliações periódicas do estado nutricional das crianças, a fim de identificar possíveis deficiências em sua alimentação, com a consequente adequação de sua dieta.

Por sua vez, com relação ao direito à saúde, os Estados devem: (i) garantir que a criança vivendo intramuros goze de padrão de saúde e de serviços de tratamento de doenças e recuperação de saúde em nível idêntico ao garantido às pessoas que não se encontram privadas de liberdade, de modo a não conferir tratamento discriminatório à estas crianças; (ii) assegurar o direito às consultas médicas regulares referentes ao acompanhamento do desenvolvimento integral da criança, que incluem o acompanhamento do crescimento (avaliação de peso, altura, etc.); vacinação e vigilância do desenvolvimento infantil; (iii) garantir o acesso a serviços permanentes de saúde e supervisão por parte de especialistas, que pode ser disponibilizado no interior das unidades prisionais ou em equipamentos de saúde próprios; (iv) ofertar atendimento especializado no tocante à saúde mental, fornecendo tratamento e acompanhamento das crianças que necessitem de tais serviços, levando-se em conta as peculiaridades do ambiente hostil carcerário e seus impactos psicológicos no desenvolvimento infantil; (v) possuir staff especializado na saúde e cuidado de crianças, tais como pediatras, psiquiatras, psicólogos, nutricionistas, cuidadores, etc., de modo a propiciar um atendimento adequado às peculiaridades deste grupo vulnerável; (vi) proporcionar treinamento básico voltado a saúde da criança a todos os funcionários que atuem no sistema prisional. 
Ainda, frente a excepcionalidade causada pelo Covid-19, o Estado deve se comprometer a: (i) testar todas as crianças e adolescentes, além de seus cuidadores; (ii) proporcionar estabelecimentos de saúde em casos de isolamento ou quarentena por motivos de saúde; (iii) monitorar quanto aos sintomas da doença; (iv) proporcionar melhorias no acesso à água, saneamento, serviços e suprimentos de higiene; (v) manter o devido processo legal e garantias processuais; (vi) manter o contato destes vulneráveis com seus responsáveis e família; (vii) prevenir a admissão de novas crianças em instalações de internação durante este período.

\section{Quais os deveres do Estado para assegurar um desenvolvimento adequado das crianças que} vivem em centros de detenção com as mães, inclusive o relacionado à integração comunitária, à socialização, à educação e à recreação?

No que tange ao desenvolvimento adequado das crianças que vivem em centros de detenção com as mães, inclusive o relacionado à integração comunitária, à socialização, à educação e à recreação, o Estado deve adotar políticas públicas, como programas sólidos e contínuos em cooperação com outras instâncias estatais e com a sociedade civil.

Em casos que, com base no melhor interesse da criança, o Estado forneça um ambiente educacional fora das prisões como medida mais apropriada, o Estado deve: (i) fornecer um meio de locomoção gratuito para levar e buscar as crianças que frequentam instituições de ensino (berçários, pré-escolas, creches e escolas), como ônibus escolares; (ii) fornecer material escolar e, em casos em que há uniforme escolar na instituição de ensino, fornecer conjuntamente esta vestimenta. Tais aparatos devem ser propiciados de forma gratuita; (iii) fornecer equipamentos, suprimentos e materiais de forma gratuita para a realização de atividades externas às instituições de ensino; (iv) ao promover a integração das crianças que vivem em centros de detenção com suas mães e as que não se encontram na mesma situação, proporcionar uma interação que respeite o princípio da igualdade e da não discriminação, de modo a proporcionar as mesmas condições de aprendizado; (v) permitir e proporcionar locomoção para pelo menos um dos responsáveis legais que encontram-se privados de sua liberdade acompanhe as reuniões e eventos escolares de seu filho ou filha.

Em casos que, com base no melhor interesse da criança, o Estado forneça um ambiente educacional dentro das prisões como medida mais apropriada, o Estado deve: (i) proporcionar um ambiente adequado para o desenvolvimento, aprendizado e recreação da criança, a qual deve possuir estímulos, acesso à saúde e alimentação, bem como ser livre de violência e discriminação. Este ambiente educacional, como berçário, pré-escola, creche, escola deve ser semelhante aos 
existentes fora da prisão; (ii) proporcionar uma educação gratuita, de qualidade e igualitária, que promova o desenvolvimento da personalidade e da capacidade física, mental, moral e social da criança. Nesse sentido, deve também fornecer material escolar para as crianças e brinquedos educativos, assim como é feito na rede pública de ensino; (iii) proporcionar um ambiente para a elaboração de atividades educacionais, lúdicas, culturais, artísticas e recreativas às crianças, que respeitem a fase de desenvolvimento infantil de cada faixa etária; (iv) disponibilizar uma equipe pedagógica com profissionais qualificados (professores, psicólogos, pedagogos, etc.) para estabelecer um plano de ensino adequado ao desenvolvimento infantil, bem como ministrar aulas considerando as peculiaridades de aprendizado de cada criança. Além disso, tais profissionais devem oferecer orientações aos responsáveis da criança para a participação destes na vida escolar de seu filho ou filha; (v) fornecer material escolar, equipamentos e suprimentos necessários para a vida escolar da criança de forma gratuita; (vi) proporcionar socialização entre as crianças que vivem intramuros, tal como promover a integração destas com as crianças que vivem fora da prisão e com a comunidade em geral tendo em vista o princípio da igualdade e da não discriminação, em consonância com o fato de que o isolamento intrínseco da prisão impõe às crianças a ausência de convivência com outras crianças de sua idade. Desse modo, o Estado deve assegurar acesso a ambientes externos como parques e áreas de recreação, não a restringindo exclusivamente ao contato familiar, mas proporcionando, ainda, a criação de vínculos de amizade e todos os outros imprescindíveis ao desenvolvimento saudável de qualquer indivíduo; (vii) proporcionar uma educação inclusiva para crianças com qualquer tipo de deficiência.

\section{Dispositivo}

Diante de todo o exposto, requer-se seja admitida a presente contribuição de amicus curiae que foi erigida a partir da análise da realidade prisional brasileira como microcosmo das violações experienciadas em toda região.

Ademais, as autoras e autores deste expressam à Corte Interamericana sua intenção de participar da audiência pública sobre o procedimento de OC, ficando ao dispor desta Honorável Corte Interamericana de Direitos Humanos.

\section{André Ribeiro Giamberardino, Melina Girardi Fachin} Alicia Marcy de Carvalho Bellegard, Ana Carolina Ribas, Bárbara Antunes Goldman, Carolina Borges Soares, Marina Bonatto, Muriel Brenna Volz 
Alana Emanuelle Plucinski Vicente, Amanda Filas Licnerski, Ana Júlia Amaro Miyashiro, Bianca Ketlyn Anderle Correia, Catarina Mendes Valente Ramos, Dilermando Aparecido Borges Martins, Fernanda de Amo Moriggi, Giovanny Padovam Ferreira, Igor Maestrelli Zarnicinski, João Daniel Vilas Boas Taques, Larissa Anacleto do Nascimento, Leonardo Silvano Rezende, Marília Martins Lopes, Paola Soldatelli Borsato, Paula Gabriela Barbieri, Pedro Cezar Grigio de Oliveira, Sthefany Felipp dos Santos, Valentina Maria Penso Bocchi 